\title{
Climate-Specific Passive Building Standards
}

Graham S. Wright and Katrin Klingenberg Passive House Institute US

July 2015

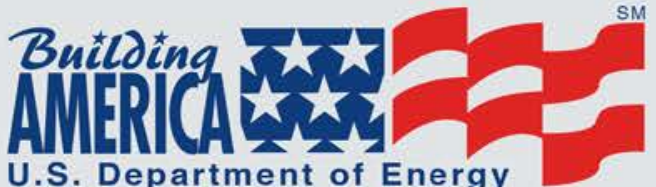




\section{NOTICE}

This report was prepared as an account of work sponsored by an agency of the United States government. Neither the United States government nor any agency thereof, nor any of their employees, subcontractors, or affiliated partners makes any warranty, express or implied, or assumes any legal liability or responsibility for the accuracy, completeness, or usefulness of any information, apparatus, product, or process disclosed, or represents that its use would not infringe privately owned rights. Reference herein to any specific commercial product, process, or service by trade name, trademark, manufacturer, or otherwise does not necessarily constitute or imply its endorsement, recommendation, or favoring by the United States government or any agency thereof. The views and opinions of authors expressed herein do not necessarily state or reflect those of the United States government or any agency thereof.

Available electronically at http://www.osti.gov/bridge

Available for a processing fee to U.S. Department of Energy and its contractors, in paper, from:

U.S. Department of Energy

Office of Scientific and Technical Information

P.O. Box 62

Oak Ridge, TN 37831-0062

phone: 865.576.8401

fax: 865.576 .5728

email: mailto:reports@adonis.osti.gov

Available for sale to the public, in paper, from:

U.S. Department of Commerce

National Technical Information Service

5285 Port Royal Road

Springfield, VA 22161

phone: 800.553 .6847

fax: 703.605.6900

email: orders@ntis.fedworld.gov

online ordering: http://www.ntis.gov/ordering.htm 


\title{
Climate-Specific Passive Building Standards
}

\author{
Prepared for: \\ The National Renewable Energy Laboratory \\ On behalf of the U.S. Department of Energy's Building America Program \\ Office of Energy Efficiency and Renewable Energy \\ 15013 Denver West Parkway \\ Golden, CO 80401 \\ NREL Contract No. DE-AC36-08GO28308 \\ Prepared by: \\ Graham S. Wright and Katrin Klingenberg \\ Passive House Institute US \\ Building Science Corporation \\ 3 Lan Drive, Suite 102 \\ Westford, MA 01886 \\ NREL Technical Monitor: Stacey Rothgeb \\ Prepared under Subcontract No.KNDJ-0-40337-05
}

July 2015 
The work presented in this report does not represent performance of any product relative to regulated minimum efficiency requirements.

The laboratory and/or field sites used for this work are not certified rating test facilities. The conditions and methods under which products were characterized for this work differ from standard rating conditions, as described.

Because the methods and conditions differ, the reported results are not comparable to rated product performance and should only be used to estimate performance under the measured conditions. 


\section{Contents}

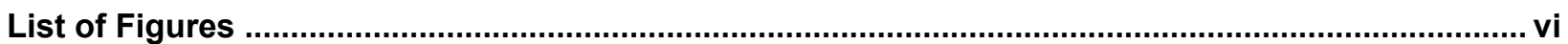

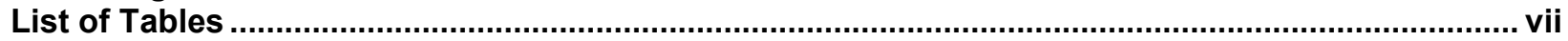

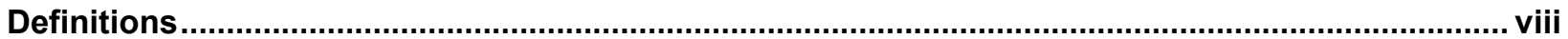

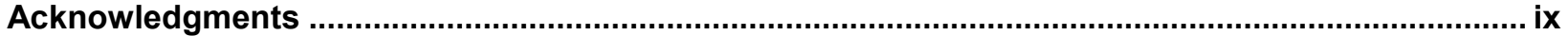

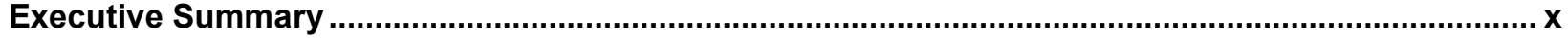

1 Introduction

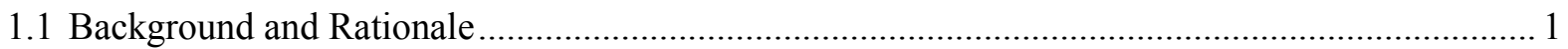

1.1.1 Recognition of a Performance-Based Standard .............................................................. 1

1.1.2 Recognition of a Standard that Was Developed Explicitly To Reduce the Carbon Footprint of Buildings and Increase Resilience ............................................................. 3

1.1.3 The PHIUS+/ZERH Partnership Has Greatly Increased Adoption of Passive Building in

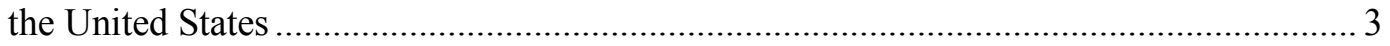

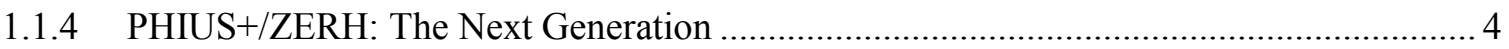

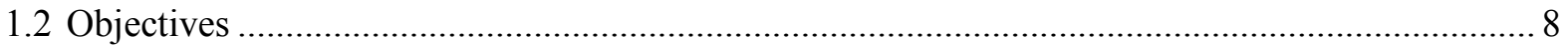

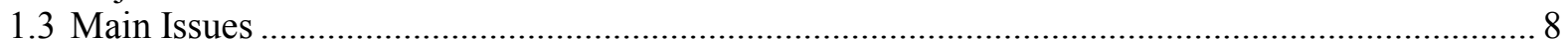

1.3.1 A Different Cost Structure Implies a Different Economic Optimum ............................... 8

1.3.2 Interaction of Criteria and Climate Misled Designers .................................................... 9

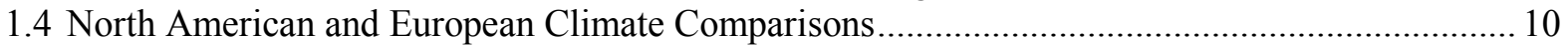

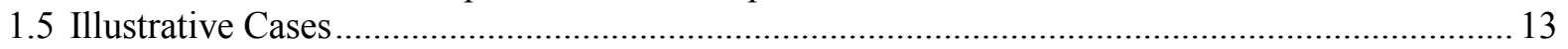

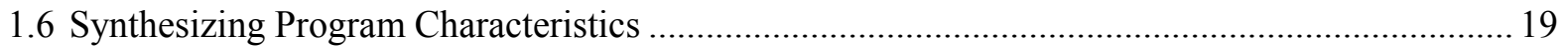

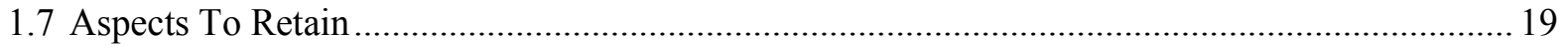

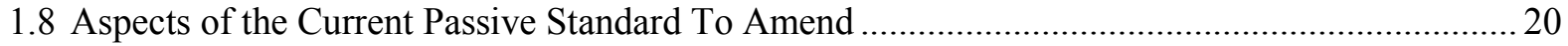

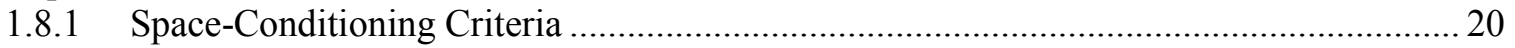

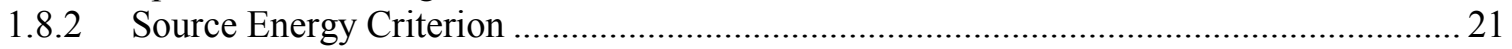

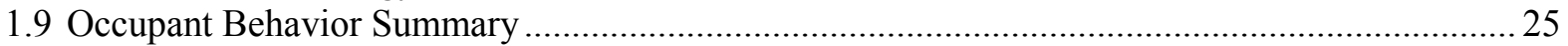

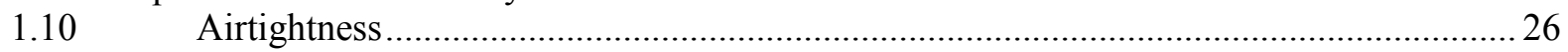

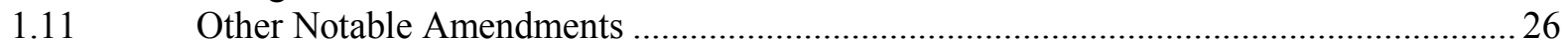

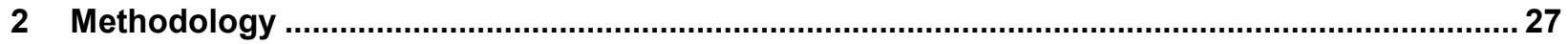

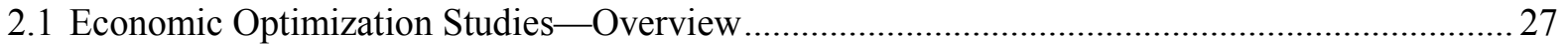

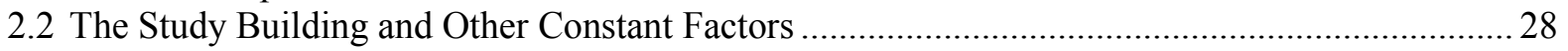

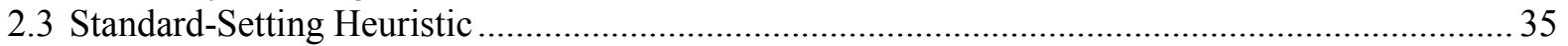

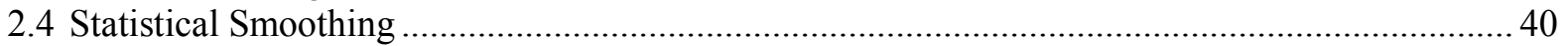

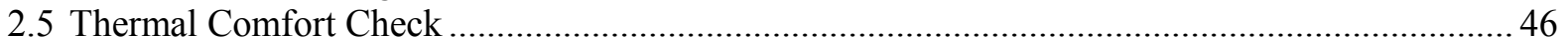

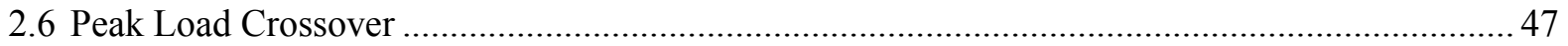

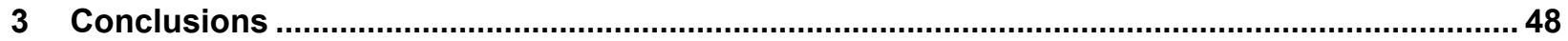

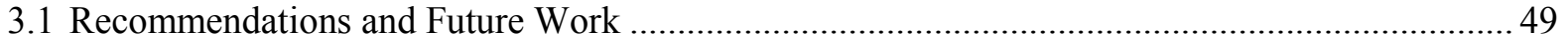

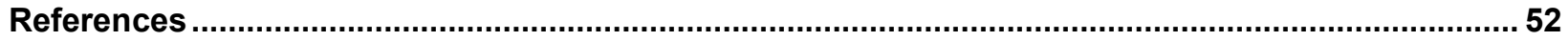

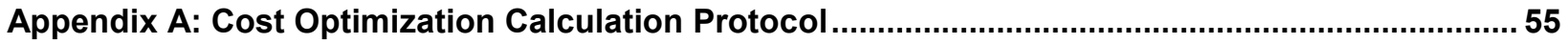

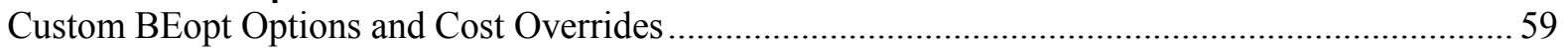

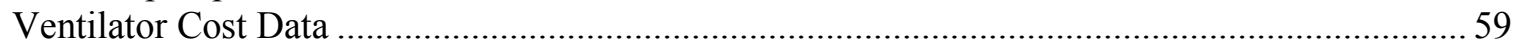

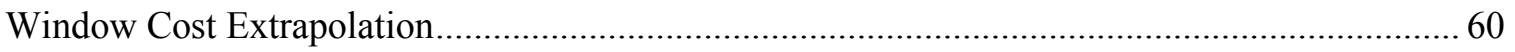

Appendix B: Cost Curves and BEopt Output for Four Example Locations ......................................62

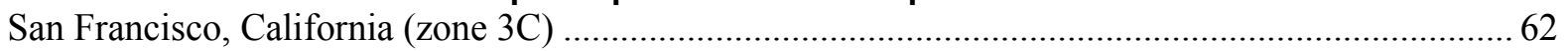

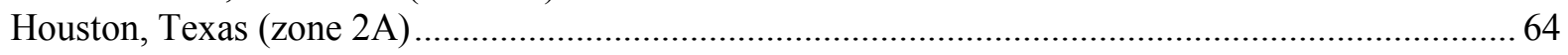

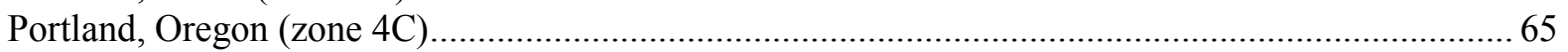

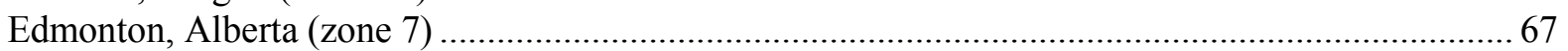

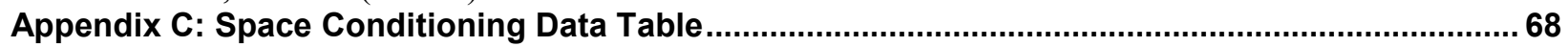

Appendix D: Statistical Modeling_Example Screening Fit........................................................... 73

Appendix E: Passive (and "Low-Grade-Energy") Measures and Strategies ..................................... 75 


\section{List of Figures}

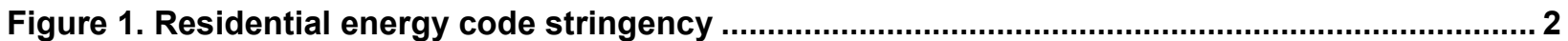

Figure 2. PHIUS+ Certified passive projects trend of the past 11 years and projection for 2015 ...... 4

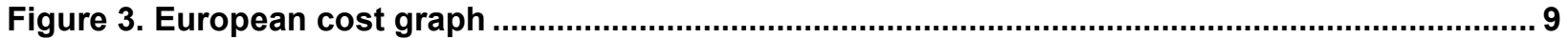

Figure 4. Diminishing returns of insulation in a 4,400 HDD climate .............................................. 13

Figure 5. Fairview Houses I and II, 2007, Urbana, Illinois ............................................................. 14

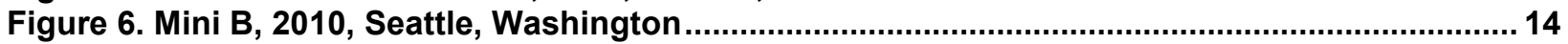

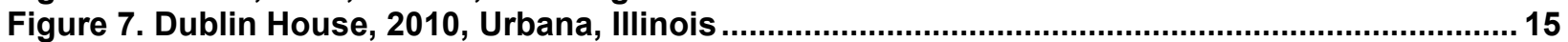

Figure 8. Modular passive home, Edmonton, Alberta ...................................................................... 16

Figure 9. IESVE indoor thermal comfort prediction without natural ventilation ............................... 17

Figure 10. IESVE indoor thermal comfort prediction with natural ventilation, perfectly executed by occupants

Figure 11. Measured performance data for the passive home in Salem, Oregon, first-year billing analysis

Figure 12. Example estimate of coincident production and use ("live utilization") of PV electricity25

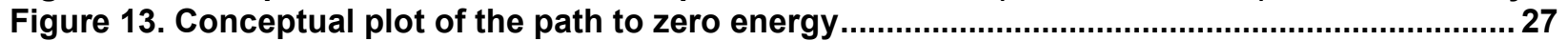

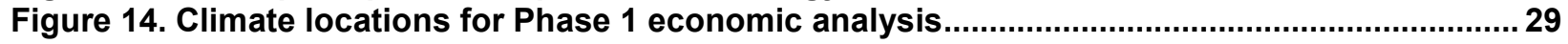

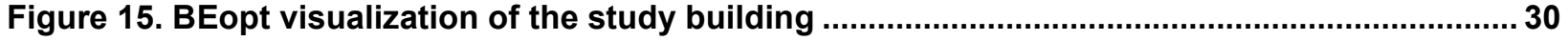

Figure 16. BEopt output screen, Chicago Illinois, at chosen cost-competitive point ..................... 31

Figure 17. Economic analysis report example, Chicago Illinois, annualized costs and first-cost premium

Figure 18. Economic analysis report example, Chicago Illinois, heating/cooling demand chart .... 32

Figure 19. Economic analysis report example, Chicago Illinois, peak load chart (per Manual J) .... 32

Figure 20. Formula for annual heating demand criterion ............................................................. 42

Figure 21. Formula for annual cooling demand criterion ................................................................ 43

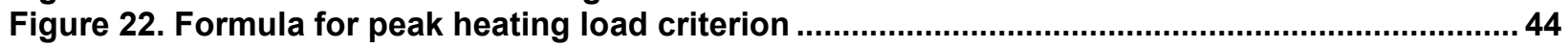

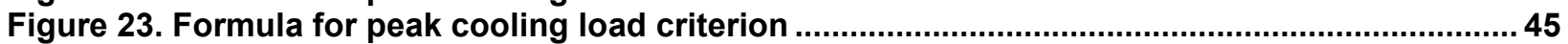

Figure 24. Interior conditions, hourly for the year, Chicago ........................................................... 47

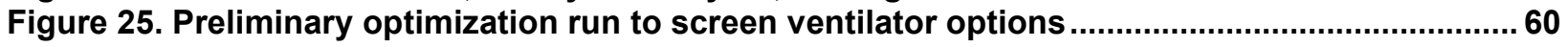

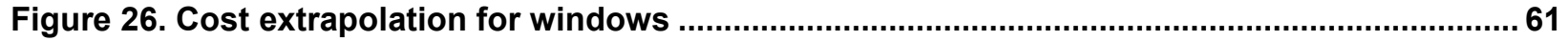

Unless otherwise noted, all figures were created by the Building Science Corporation team. 


\section{List of Tables}

Table 1. Historical Development of High-Level Performance Programs and Their Comparison ....... 7

Table 2. South Glazing Concentration by Zone, Certified and Precertified Projects ........................ 10

Table 3. Design Temperatures and Degree Days, North America, Coastal, East.............................. 10

Table 4. Design Temperatures and Degree Days, North America, Pacific Northwest ...................... 11

Table 5. Design Temperatures and Degree Days, United States, Midcontinent, East .......................11

Table 6. Design Temperatures and Degree Days, United States, Midcontinent, West-Central ........ 12

Table 7. Design Temperatures and Degree Days, United States, Midcontinent, North ..................... 12

Table 8. Installed Heating Capacity for 3567 Claxton Crescent ........................................................ 18

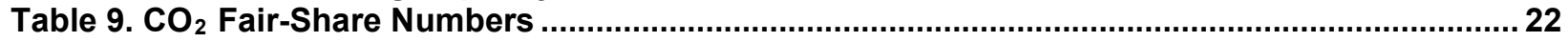

Table 10. Lighting and Plug Loads Example Calculation, Standard-Adaptation Study Building ..... 23

Table 11. Economic Analysis Report, Example Table for Chicago, Illinois ......................................33

Table 12. Option Configuration (subset) at the Optimal Points Listed in Table 11 ........................... 34

Table 13. Zone Median Space-Conditioning Targets by Diminishing Returns Heuristic .................. 38

Table 14. Zone Median Space-Conditioning Targets by PV Start Rule .......................................... 39

Table 15. Zone-by-Zone All-Points Median Percentage Reductions From Benchmark (Pre-

Recalculation Data)

Table 16. All-Points Median Percentage Reductions From Benchmark ....................................... 40

Table 17. PHIUS Technical Committee Resolutions.................................................................... 55

Table 18. BEopt input-Options Screen, Example for Chicago …................................................... 56

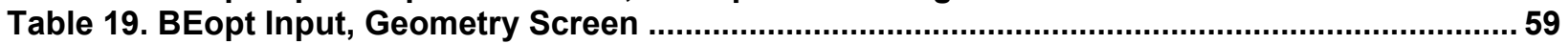

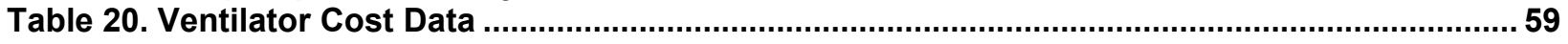

Unless otherwise noted, all tables were created by the Building Science Corporation team. 


\section{Definitions}

ACH50 Air changes per hour at 50 Pascals pressure difference

ASHRAE American Society of Heating, Refrigerating and Air-Conditioning Engineers

BA Building America

BEopt $^{\mathrm{TM}} \quad$ Building Energy Optimization (software)

CDD65 Cooling Degree Days, base $65^{\circ} \mathrm{F}$

CFM50 Cubic feet per minute of air flow at 50 Pascals pressure difference

CFM75 Cubic feet per minute of air flow at 75 Pascals pressure difference

$\mathrm{CO}_{2} \quad$ Carbon Dioxide

DDHR Dehumidification design humidity ratio

DOE U.S. Department of Energy

EPS Expanded Polystyrene

ERV Energy Recovery Ventilator

HDD65 Heating Degree Days, base $65^{\circ} \mathrm{F}$

HRV Heat Recovery Ventilator

iCFA Conditioned floor area by interior dimensions

IECC International Energy Conservation Code

IESVE Integrated Environmental Solutions Virtual Environment

IPCC Intergovernmental Panel on Climate Change

OSB Oriented Strand Board

PHI Passivhaus Institute (Darmstadt, Germany)

PHIUS Passive House Institute US

PHPP Passive House Planning Package

PV Photovoltaic

RESNET Residential Energy Services Network

SSCD Specific space cooling demand (annual kBtu per square foot of iCFA)

SSHD Specific space heating demand (annual kBtu per square foot of iCFA)

TC Technical Committee

WUFI Wärme und Feuchteinstationär (Heat and Moisture, Transient)

XPS Extruded Polystyrene

ZERH Zero Energy Ready Home 


\section{Acknowledgments}

The authors thank Building Science Corporation, specifically Betsy Pettit for her tremendous support and final reviews; the PHIUS Technical Committee for its critical contribution to this work; the PHIUS staff team specifically James M. Kernagis for continued technical advice and Michael Knezovich for editorial advice.

For their many and significant contributions to this study, the authors thank the members of the PHIUS Technical Committee:

Ryan Abendroth

Florian Antretter

Thorsten Chlupp

Adam Cohen

Prudence Ferreira

Stuart Fix

Achilles Karagiozis

Russell Richman

John Semmelhack

Jesse Thomas 


\section{Executive Summary}

In 2012, the U.S. Department of Energy (DOE) recognized the value of performance-based passive building standards when it joined with Passive House Institute US (PHIUS) to promote DOE's Challenge Home program in tandem with the PHIUS+Certification program. Since then, the number of passive building projects that have been certified under the partnership has grown exponentially because of some synergy. Passive building represents a well-developed approach to arrive at the envelope basis for zero energy and energy-positive projects by employing performance-based criteria and maximizing cost-effective savings from conservation before implementing renewable energy technologies. The Challenge Home program evolved into the Zero Energy Ready Home (ZERH) program in a move toward 1) attaining zero energy and 2) including active renewable energy generation such as photovoltaics (PV) - toward the zero energy goal.

A synthesis of the two programs, PHIUS+ and ZERH - which combines optimized performancebased envelope design guidelines and zero energy goals - has the potential to make net zero energy a mainstream market force. But experience to date has identified a critical obstacle to wide-scale adoption across the nation: the passive/conservation performance metric currently used as the envelope design guideline for space-conditioning criteria (following the German Passivhaus standard) is not responsive to the wide diversity of climate and energy market conditions in the United States.

Passive design principles (superinsulation, airtight envelopes, elimination of thermal bridges, etc.) were pioneered in North America in the 1970s and 1980s and refined in Europe in the 1990s. These principles are universally effective in significantly reducing heating and cooling loads. However, a single rigid performance metric developed in Germany has led to limited uptake of passive building principles in many regions of the United States. It has also sometimes promoted design decisions that had negative effects on economic feasibility and thermal comfort.

This study has two objectives:

- Validate (in a theoretical sense) verifiable climate-specific passive standards and spaceconditioning criteria that (1) retain ambitious, environmentally necessary energy reduction targets and (2) are economically feasible. Such standards provide designers an ambitious but achievable performance target on the path to net-zero energy.

- Develop simplified formulas for inclusion in a design and verification software tool that allows custom criteria to be generated based on specific climate and energy cost parameters for any particular location.

The approach to arrive at this new set of criteria is to critically reevaluate the current Germanderived criteria in light of the issues discovered. A volunteer technical expert advisory council called the PHIUS Technical Committee (TC) has assisted the authors in the process; the results presented here reflect consensus votes by this volunteer expert body.

The main guiding criteria comprise three "pillars": 
- Space conditioning (limits on heating and cooling loads) that incent passive measures

- A source energy limit that encourages the efficient use of equipment and meets environmentally required reduction targets with a "conservation first" goal

- Airtightness requirements to ensure that highly insulated envelopes do not develop moisture problems that will lead to significant failures of the envelope components.

The bulk of the work is concerned with restructuring and resetting the heating and cooling load limits in a way that better guides the designer toward cost-competitive levels of investment in the passive measures such as insulation and heat recovery ventilation, which reduce heating and cooling loads. This is done in a climate-sensitive way. The basic approach is to use NREL's Building Energy Optimization software (BEopt) with its embedded National Residential Energy Efficiency Measures database to:

- Cost-optimize an energy-saving upgrade package for a study building in 110 climate locations in North America.

- Note the heating and cooling load performance achieved.

- Curve-fit the data to local climate parameters such as degree-days and design temperatures. The optimizations are constrained with strict airtightness requirements and minimum window U-values to ensure that building durability and winter comfort are not compromised in the quest for energy savings.

The result is a set of simple formulas that can be embedded into building energy modeling software to set the heating and cooling criteria for any location in which the local climate parameters are known.

The German-derived source energy and airtightness criteria were reevaluated. Although the newspace conditioning criteria would still be based on floor area (using a new simplified conditioned floor area), the proposed source energy and airtightness criteria will use different scaling rules. The airtightness limit will scale with envelope surface area instead of building volume. A commensurate change from ACH50 measurement to CFM50/ $\mathrm{ft}^{2}$ of gross envelope area is recommended; the source energy limit for residential projects would scale per person based on design occupancy instead of on floor area. This limit would remain consistent with the global total carbon dioxide emissions limits brought forward by the Intergovernmental Panel on Climate Change.

In summary, adaptations are proposed for all three pillars:

- The airtightness requirement was reconsidered on the basis of avoiding moisture and mold risk. The proposed change is from a limit of $0.6 \mathrm{ACH} 50$ to $0.05 \mathrm{CFM} 50 / \mathrm{ft}^{2}$ of gross envelope area (or 0.08 CFM75). This change allows the airtightness requirement to scale appropriately based on building size.

- The source energy limit was reconsidered on the basis of the global carbon dioxide emission budget. The following changes are proposed to make the scoring fairer and the calculation more accurate: 
- Change to a per-person limit rather than a limit measured by square feet of floor area for residential projects.

- Correct the source energy factor for grid electricity in the calculation protocol to 3.16, which is consistent with the U.S. national average.

- Adopt lighting and miscellaneous plug load defaults at $80 \%$ of the Residential Energy Services Network standard.

○ Set the source energy limit to $6,200 \mathrm{kWh} /$ person/year and tighten it to 4,200 $\mathrm{kWh} /$ person/year within a few years.

- Apply the limit to the source energy calculated net of the estimated fraction of on-site PV or other renewable electricity generation that is used on site as it is produced. This accounts for PV the same way solar hot water is accounted for.

The space-conditioning criteria were reconsidered on the basis of economic feasibility. The proposed changes are to:

- Shift to mandatory thresholds on annual heating and cooling demands and peak heating and cooling loads that are climate specific to a project's location. These thresholds are aimed at a near-optimal "sweet spot" with slightly more energy savings than would occur at the cost-optimum point calculated by the Building Energy Optimization software. This shift will ensure that efficiency measures will be reasonably cost-competitive and will provide some increased resilience benefits.

- Adopt a simplified inclusive interior-dimension reference floor area.

The outcome of this study yields a cost-effective performance-based standard that would reduce energy consumption in buildings on a national average by an estimated $86 \%$ for heating and $46 \%$ for cooling; the peak heating load (and system size) would be reduced by $77 \%$ and the peak cooling load would be reduced by $69 \%$. Total source energy use would also be reduced for buildings consistent with limiting global temperatures from warming by more than $2{ }^{\circ} \mathrm{C}$.

By its structure, the proposed standard addresses three hurdles to source zero energy. The designer's attention is directed first to reducing heating and cooling energy use by passive means (including the use of some mechanical devices), then to reducing total energy demand by using efficient equipment (and some renewables), and finally to source zero energy by additional renewable energy generation.

The authors recommend adopting the standard as the basis for the next-generation ZERH as costcompetitive envelope guidelines to achieve zero energy and active generation. 


\section{Introduction}

\subsection{Background and Rationale}

Given the large proportion of energy used in buildings ( $40 \%$, according to the U.S. Energy Information Administration [EIA 2013]) and growing consensus about the economic and social costs of climate change, a movement to decrease energy demand through conservation and to increase the use of renewables is coalescing.

In 2010 the European Parliament committed to broad levels of carbon reductions per the Kyoto Protocol to the United Nations Framework Convention on Climate Change. The protocol called for adopting passive building strategies and scaling up renewable energy supplies. The European Union committed its members to reaching near zero energy buildings by 2020 (EU 2010).

Europe has always focused on performance metrics. In recent years - beginning with the German Passivhaus performance standard - the passive design methodology has gained widespread adoption. Variations on that approach and metric have been codified in countries such as Belgium, Sweden, and Switzerland. (Jacobson 2013; Dockx 2013)

Similar efforts are underway in the United States. For example, the 2030 Challenge by architect Ed Mazria calls for buildings to be carbon neutral by 2030. The U.S. Department of Energy (DOE) has led efforts to improve building energy performance through programs such as Building America (BA). In 2012, DOE recognized the value of performance-based passive building standards when it joined with Passive House Institute US (PHIUS) to co-promote DOE's Challenge Home program. Challenge Home was an evolution of the successful Builders Challenge program. In 2014, Challenge Home was renamed the Zero Energy Ready Home (ZERH) program; it emphasizes that homes are being designed to accommodate renewables.

Within the PHIUS+/ZERH partnership, the PHIUS+ Certification program includes passive building design verification and Residential Energy Services Network (RESNET)-approved quality assurance protocols. The certification program was adjusted to include some prescriptive requirements to meet ZERH criteria. (The 2030 challenge does not prescribe any efficiency or conservation measures on the way to carbon neutrality; the ZERH program, however, requires high-performance envelope measures.)

The PHIUS+/ZERH partnership remains significant for several reasons that are discussed in Section 1.1.1 through Section 1.1.4.

\subsubsection{Recognition of a Performance-Based Standard}

By recognizing the PHIUS+ program - which is fundamentally a performance-based standard with a prescriptive component related to ZERH requirements-ZERH acknowledged the value of performance-based standards in general and of the passive building standard in particular. This is a critical recognition in a historical context. In 1970, the White House Council on Environmental Quality issued its First Annual Report along with a presidential message to Congress (Train et al. 1970). The report included a comprehensive analysis of the environmental threats that face the United States and made the case for establishing the U.S. Environmental Protection Agency. Notably, the report called attention to the possibility of climate change. 
Once the U.S. Environmental Protection Agency was established, its attention to environmental issues combined with the OPEC oil embargo in 1973 led to significant government funding of energy-efficiency research (ASE 2013). The first commercial energy-efficiency design guidelines were established by ASHRAE and published in 1975 as Standard 90-75. The guidelines were later renamed the Model Energy Code and further iterations followed. The Model Energy Code is the predecessor to today's ASHRAE 90.1.

Significantly, in 1976 the first proposed federal legislation and national building energy code specified a performance-based approach rather than the now-familiar prescriptive/checklist improvements over a baseline home. The proposed legislation required all buildings to meet an energy target per square foot as verified by a computer model. In the face of opposition from the building industry, the performance-based requirement was replaced by a prescriptive approach in the legislation that was eventually enacted. The subordination of the performance-based requirement had a longstanding effect on the development of codes and efficiency programs.

In 1994 the nonprofit International Code Council was founded. It published the first edition of the International Energy Conservation Code (IECC) in 1998 and has since issued revisions in 3year code cycles. The resulting improvements (by estimated percentage) over the first guidelines published by ASHRAE in Standard 90-75 that followed are shown in Figure 1 by each iteration and then by versions of IECC (EIA 2008). The data from 2006 IECC to 2012 IECC (ICC 2012, not shown here) represent another major $30 \%$ reduction.

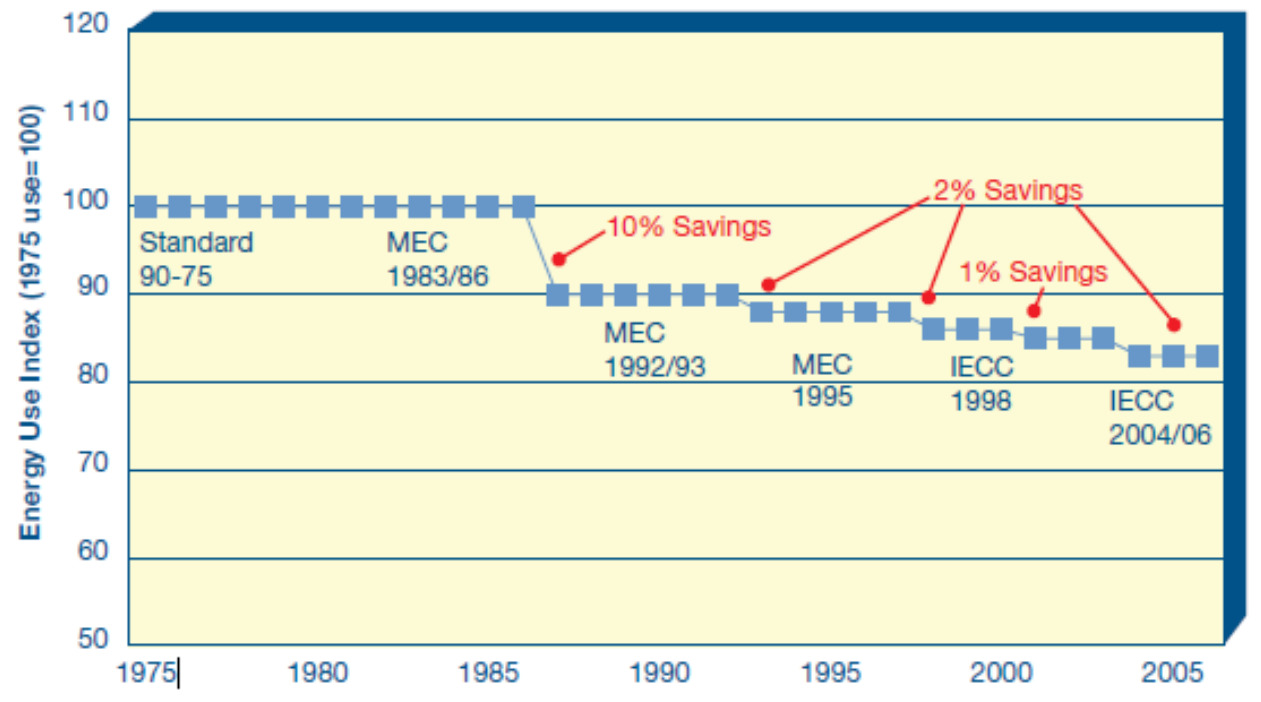

Figure 1. Residential energy code stringency

Although code has trended toward greater energy efficiency, lawmakers and policymakers are challenged to accurately assess actual energy-efficiency performance — and improvements — of the built environment in absolute and measurable terms. That is because quantifying and verifying actual performance improvements is not the main objective of a mostly prescriptive regime. Prescriptive standards apply a linear, additive approach of individual measures that fail to look at buildings as systems and fail to account for the "whole being larger than the sum of its 
parts." Synergies cannot be accounted for unless a building system is modeled intentionally to exploit them during the design process with a model designed for that purpose. Therefore, an integrated design process that is guided by appropriate performance targets would yield greater efficiencies than conventional building design methodologies and energy accounting.

Europe's building energy codes have traditionally followed the performance-based model; highperformance programs or low-energy home designations are characterized by absolute energy metrics or energy use intensity indexes as benchmarks to govern various levels of energy use in buildings. Buildings can then be directly compared in terms of their energy use intensities and can progress toward absolute efficiency goals. The recognition of the PHIUS+ program by ZERH is a step toward leveraging the advantages of performance criteria and toward alignment with international approaches to energy and carbon reduction efforts.

\subsubsection{Recognition of a Standard that Was Developed Explicitly To Reduce the Carbon Footprint of Buildings and Increase Resilience}

The fundamental principles behind passive building - superinsulation, airtight envelopes, etc.were developed in the 1970s and 1980s in the United States and Canada. Much of that work was done with government funding that responded to environmental, economic, and geopolitical crises. The terms passive house and passive housing were coined by early Canadian pioneers in the 1970s (Dumont et al. 1978) and were later used by the renowned physicist William Shurcliff in the 1980s and others (Shurcliff 1982, 1986). The term passive expressed then (as it does today) an effort to reduce heating energy consumption in buildings to nearly zero by limiting heat loss and optimizing gains via insulation, high-performance windows, and airtightness.

Envelope performance is guided by the low peak load design tenet that provides resiliency as a prime benefit: the home needs only a "micro-load" mechanical backup system for normal operation and can "coast" thermally through power outages. By 1986 many homebuilders were designing their homes accordingly and Shurcliff declared the technology mature (Shurcliff 1988). By the end of the 1980s as many as 30,000 of these homes had been built in the United States and Canada (Nisson and Dutt 1985).

As interest in conservation and efficiency foundered in North America (Biello 2010), the German physicist Wolfgang Feist - initially with Swedish Collaborator Dr. Bo Adamson and continuing today at the Passivhaus Institut (PHI) — continued to refine the principles and develop a modeling tool and an energy metric known in German as Passivhaus.

The first convincing German research project that employed the low-load home design tenet was a four-townhouse development in Kranichstein in Darmstadt Germany that was completed in 1991. The project reduced energy demand and system size by a factor of 10 in the central European climate zone. The passive metric developed from this effort guided designs toward very low peak loads.

\subsubsection{The PHIUS+/ZERH Partnership Has Greatly Increased Adoption of Passive Building in the United States}

Since PHIUS and DOE announced the alignment of the PHIUS+ program with the Challenge Home program (now ZERH), the growth in PHIUS+ Certified projects has increased dramatically. The growth continues (see Figure 2). The fastest-growing typology is multifamily-large multiunit projects are underway and many more are in the planning stages. 


\section{PHIUS+ Certified Projects}

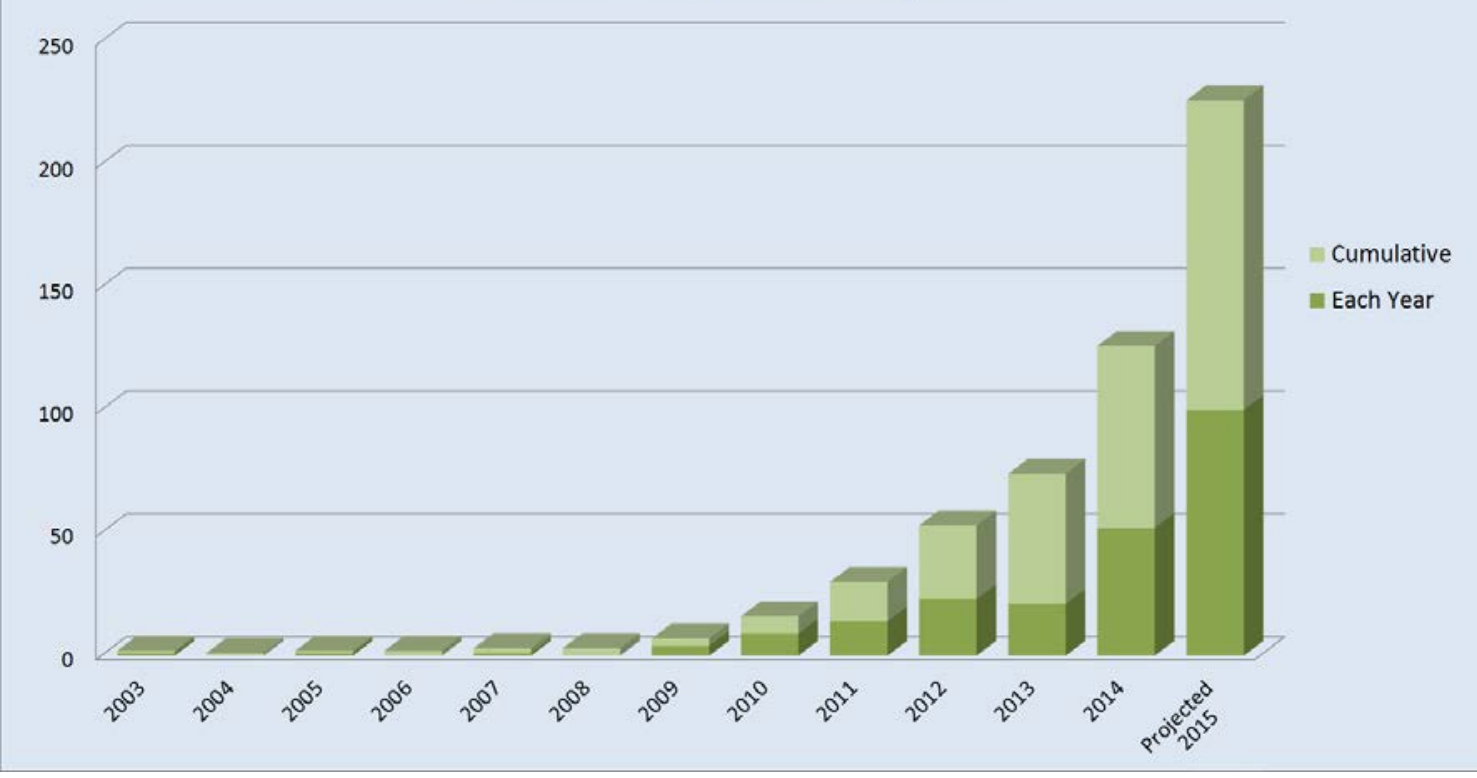

Figure 2. PHIUS+ Certified passive projects trend of the past 11 years and projection for 2015

In Europe, the uptake of passive building principles provided incentives for manufacturers to innovate and produce a growing range of high-performance building components including doors, windows, air-sealing products, and ventilation equipment. The increased uptake of passive houses in Europe has also produced economies of scale that have reduced the prices of premium components significantly. This development has effectively created an entirely new market segment and economic opportunities.

The same dynamic is operating in North America. PHIUS launched a window certification program concurrently with the PHIUS+/ZERH program. The PHIUS Certified Data for Windows program analyzes manufacturer-supplied data and evaluates products for suitability in Passive House projects by climate (using the standard ASHRAE/DOE North American climate zones). Since the launch of the program, 10 manufacturers have submitted hundreds of models for evaluation; 130 models have been recommended for at least one climate zone. Significantly, the roster of manufacturers includes mostly domestic companies including a very large mainstream window firm Marvin Windows and Doors.

\subsubsection{PHIUS+/ZERH: The Next Generation}

Combining passive building principles and low peak load design tenets with a zero energy target has an intrinsic logic: reduce demand and peak loads to a point at which the envelope improvements are cost-effective and all the building's needs can be met with a minimized and affordable and active renewable energy system to reach zero energy. Designers and builders are recognizing passive house as a critical path to zero. Based on the growth shown so far, the combination has potential to make zero energy - achieved via passive building - into a massmarket phenomenon. However, a significant obstacle to wide-scale adoption remains; removing that obstacle is the motivation of the work and results described here. 
The problem is that passive performance targets have not been optimized by climate zone. Until now, the European energy metric of $4.75 \mathrm{kWh} / \mathrm{ft}^{2}$ annual load has served as a one-size-fits-all design target for all climates. In some climates this has led to very costly projects; in others it has produced significant thermal comfort issues. In short, that metric has led to poor design decisions in climates that are significantly different from the central European zone with its moderately cold heating-dominated climate. Even though the underlying Passive House design principles have proven effective in all climate zones, a one-size-fits-all performance target has proved to be a disincentive in many climate zones.

Some history of the European standard's application in the United States is in order. In 2002 PHIUS cofounder Katrin Klingenberg completed a Passive House proof of concept for the United States - the Smith House, which was a single-family home that significantly reduced energy consumption (Stecher and Klingenberg 2008). It was followed a few years later by the two houses (Fairview I and II) built by e-co lab, which was a community housing development organization. These houses were also monitored and tested by the DOE BA partner IBACOS. A BA report was published about Fairview II (Stecher and Allison 2012).

PHIUS was founded in 2007 and has since trained 1,800 professionals and become the leading Passive House project certifier in North America. From the beginning, PHIUS' work in the United States was informed by — but was mostly independent from — the German institute. That was by necessity because North America's multiple and more extreme climate zones presented different challenges for passive building than do the zones in the central European climate.

Almost every project offered a new climate challenge. These circumstances sometimes resulted in projects that had the same overheating problems as early "mass-and-glass" designs from the 1970s. In other instances - in Louisiana for example - the German-derived standard did not account for humidity loads and predicted cooling demands inaccurately.

Driven by building science, PHIUS sought to resolve the new issues presented by multiple and more extreme climate zones in the United States. It drew on the original writings and research done in North America in the 1970s and 1980s and the good work of the Germans. PHIUS then collaborated with leading building science experts in the United States and Canada such as Building Science Corporation.

Although PHIUS and the Passive House community have enjoyed substantial success, a review of hundreds of projects across North American climate zones showed clearly to PHIUS and the growing community of Passive House practitioners that the German Passivhaus standard was significantly challenged and cost-prohibitive in vast areas of North America. In areas such as the Pacific Northwest, uptake of Passive House has grown quickly because the climate is similar to that in which the German standard was derived. But in others, the energy target has been a disincentive to using Passive House as a platform for zero energy.

The work described here aims to retain the proven value of passive design techniques (optimizing the envelope for example) and to use the National Renewable Energy Laboratory's Building Energy Optimization (BEopt ${ }^{\mathrm{TM}}$ ) tool to set new passive building metrics that reflect climate-specific requirements, national construction costs, and regional energy costs. The main objective is to propose a standard that makes such necessary adjustments and can function as an easy-to-understand and use proxy for "how far to go" first with passive measures before adding 
efficient systems and renewable energy systems. The goal is a simple yet fine-grained performance-based design methodology that guides the designer to identify the most costeffective path to zero with the greatest overall benefits to building owners and society.

The work retains the ambition of the Passive House movement to reduce building energy requirements and carbon footprints, all while creating supremely comfortable and resilient buildings and spurring innovation in building science and in the building component industry.

The refined climate-specific passive building standard is proposed as the basis for the nextgeneration ZERH. A fundamental premise of this study is that performance-based metrics are useful to advance national and global energy and carbon reduction goals. ZERH and PHIUS+ are already employing performance-based guidelines and agree on this premise. PHIUS brings a methodology to the table that employs passive building techniques that prioritize savings from passive measures; ZERH brings to the table (1) a methodology through BEopt to evaluate the cost-effectiveness of all measures and (2) a strong approach to field quality assurance.

Table 1 shows the historical development of high-performance building programs that spans from the first-generation Passive House pioneers to the newly proposed targets. It outlines their respective reduction targets for heating loads, cooling loads, and system size. The proposed new standard that this study yields appears to be in close alignment with the targets of the first generation. See Holladay (2010) for a history of the period 1974-1986. 
Table 1. Historical Development of High-Level Performance Programs and Their Comparison

\begin{tabular}{|c|c|c|c|c|}
\hline & How Far To Reduce Heating Load & $\begin{array}{l}\text { Prescriptive } \\
\text { or } \\
\text { Performance } \\
\text { Emphasis } \\
\end{array}$ & Approach to Total Energy & Approach to Quality Assurance \\
\hline $\begin{array}{l}\text { First-Generation } \\
\text { Passive House/ } \\
\text { Super-Insulation } \\
\text { (1973-1989) }\end{array}$ & $\begin{array}{c}\text { Heat loss (peak load) } 60 \%-80 \% \text { reduction, } \\
\text { annual heating demand } 80 \%-90 \% \text { reduction } \\
\text { (from pre-1980 conventional). Space heating } \\
\text { peak } \sim 10-17 \mathrm{~W} / \mathrm{m}^{2}\left(3.17-5.39 \mathrm{Btu} / \mathrm{h} / \mathrm{ft}^{2} \text { or } \sim 1.0-\right. \\
1.7 \mathrm{~W} / \mathrm{ft}^{2} \text { ), space-heating demand less than } \\
\text { water heating. Point source heating sufficient, } \\
\text { airtight construction. }\end{array}$ & $\begin{array}{l}\text { Mostly } \\
\text { performance }\end{array}$ & Not addressed & Craft, airtightness test \\
\hline $\begin{array}{c}\text { PHI } \\
\text { (1996-Present) }\end{array}$ & $\begin{array}{l}\text { Peak load limit } \sim 10 \mathrm{~W} / \mathrm{m}^{2}\left(3.17 \mathrm{Btu} / \mathrm{h} / \mathrm{ft}^{2} \text { or } 1\right. \\
\left.\mathrm{W} / \mathrm{ft}^{2}\right) \text { alternative limit } 4.75 \mathrm{kBtu} / \mathrm{ft}^{2} \text { annual } \\
\text { heating and cooling demand each. Additional } \\
\text { allowance for dehumidification on the cooling } \\
\text { side in humid climates, supply air heating } \\
\text { sufficient, airtightness } 0.6 \mathrm{ACH} 50 .\end{array}$ & $\begin{array}{l}\text { Mostly } \\
\text { performance }\end{array}$ & $\begin{array}{c}\text { Annual source energy limit, } \\
\text { floor area based }\end{array}$ & $\begin{array}{l}\text { Craft, airtightness test, ventilation } \\
\text { commissioning }\end{array}$ \\
\hline $\begin{array}{l}\text { DOE Challenge } \\
\text { Home/ZERH } \\
\text { (2011-Present) }\end{array}$ & $\begin{array}{l}\text { IECC } 2012 \text { insulation levels, ducts inside, } \\
\text { windows R 2.5-3.7, airtightness 1.5-3 ACH50, } \\
\text { annual heating } \sim 50 \% \text { reduction from } 2009 \text { BA } \\
\text { benchmark, annual cooling } \sim 25 \% \text { reduction. }\end{array}$ & $\begin{array}{l}\text { Dual path-all- } \\
\text { prescriptive or } \\
\text { prescriptive }+ \\
\text { performance }\end{array}$ & $\begin{array}{c}\text { Home Energy Rating } \\
\text { System rating before } \\
\text { photovoltaic (PV) (site } \\
\text { energy reduction relative to } \\
\text { base case of same design.) }\end{array}$ & $\begin{array}{l}\text { Craft, extensive checklist, third-party } \\
\text { quality assurance/quality control }\end{array}$ \\
\hline $\begin{array}{c}\text { PHIUS+ } \\
\text { (2012-Present) }\end{array}$ & $\begin{array}{l}\text { Peak load limit } \sim 10 \mathrm{~W} / \mathrm{m}^{2}\left(3.17 \mathrm{Btu} / \mathrm{h} / \mathrm{ft}^{2} \text { or } 1\right. \\
\left.\mathrm{W} / \mathrm{ft}^{2}\right) \text { Alternate limit } 4.75 \mathrm{kBtu} / \mathrm{ft}^{2} \text { annual } \\
\text { heating and cooling demand each. Additional } \\
\text { allowance for dehumidification on the cooling } \\
\text { side in humid climates, airtightness } 0.6 \mathrm{ACH} 50 \text {. }\end{array}$ & $\begin{array}{l}\text { Prescriptive }+ \\
\text { performance }\end{array}$ & $\begin{array}{l}\text { Annual source energy limit, } \\
\text { floor area based }\end{array}$ & $\begin{array}{l}\text { Craft, extensive checklist, third-party } \\
\text { quality assurance/quality control, } \\
\text { including airtightness test and full } \\
\text { commissioning of systems including } \\
\text { verification of actual energy use of } \\
\text { components under operation }\end{array}$ \\
\hline $\begin{array}{l}\text { Proposed for Next } \\
\text { Generation } \\
\text { (2015) }\end{array}$ & $\begin{array}{l}\text { Based on economic analysis, "cost-competitive" } \\
\text { level. Climate-specific limits on heating and } \\
\text { cooling demands and loads. Peak heat load } \\
\sim 77 \% \text { reduction, annual heating } \sim 86 \% \text { reduction } \\
\text { from } 2009 \text { BA benchmark. Peak cooling } \sim 69 \% \text {, } \\
\text { annual cooling } \sim 46 \% \text { reduction. }\end{array}$ & $\begin{array}{l}\text { Mostly } \\
\text { performance }\end{array}$ & $\begin{array}{l}\text { Annual source energy limit, } \\
\text { per person based for } \\
\text { residential, floor area based } \\
\text { for nonresidential }\end{array}$ & $\begin{array}{l}\text { Craft, third-party quality } \\
\text { assurance/quality control, including } \\
\text { airtightness test and full commissioning } \\
\text { of systems with verification of actual } \\
\text { energy use of components under } \\
\text { operation, post commissioning after } 1 \\
\text { year of occupancy }\end{array}$ \\
\hline
\end{tabular}




\subsection{Objectives}

The objectives of this study were to:

- Validate the proposition that climate-zone-specific energy-performance criteria for heating and cooling can guide designers toward cost-competitive levels of investment in passive measures in balance with other conservation measures and renewables.

- Develop simplified formulas that are suitable for inclusion in building energy modeling and verification software to set the criteria based on local climate parameters with a quick calculation (as opposed to a full life cycle analysis for each project).

\subsection{Main Issues}

In 2007, PHIUS started to promote and apply the European energy metrics in all climates of the United States and Canada. Since then more than 100 projects that meet those criteria have been completed. Two main issues were identified and are discussed in Section 1.3.1 and Section 1.3.2.

\subsubsection{A Different Cost Structure Implies a Different Economic Optimum}

In the climate of central Europe, the relationship between the annual demand and low peak load was such that a building that achieves $15 \mathrm{kWh} / \mathrm{m}^{2} /$ year $\left(4.75 \mathrm{kBtu} / \mathrm{ft}^{2} /\right.$ year $)$ annual heating demand would generally meet the peak load definition of $10 \mathrm{~W} / \mathrm{m}^{2}\left(3.17 \mathrm{Btu} / \mathrm{ft}^{2} /\right.$ year $)$. Furthermore, it was found or claimed that the level of envelope investment needed to achieve this performance was cost-competitive, even roughly cost-optimal-marking the point where one could "tunnel through the cost barrier" to higher performance (Laustsen 2008). The phrase "Tunneling through the cost barrier" implies saving enough cost on the mechanical and heat distribution systems to offset the increased investment in the envelope and enclosure. This offset principle has been a key argument for the concept in Europe.

In North America the effect of tunneling through the cost barrier could not be observed. Taking some cost out of the heating and cooling system and putting it into the envelope is a valid concept, but savings were less significant for the following reasons:

- Unlike Germany, the United States and Canada do not have such a clear breakpoint at which an expensive baseline boiler and hydronic distribution system (the typical heating system in Europe) can be eliminated for great savings.

- Specialty small-capacity heating and cooling devices provide little cost savings relative to high-capacity commodity equipment.

- Fuel prices are generally much lower in the United States, which further weakens the argument of cost per kilowatt-hour saved. The reality of the different cost picture in North America must be acknowledged.

The European cost-effectiveness model did not take the cost of PV into account. At the time the standard was formulated, PV was very expensive and not considered cost-competitive.

Therefore, the standard's cost-effectiveness argument does not take the goal of achieving zero energy — or the necessary investment - into account. The cost graph shown in Figure 3 is based on PHI data. It shows cost increasing exponentially once PV is added and after $15 \mathrm{kWh} / \mathrm{m}^{2}-\mathrm{yr}$ annual heat demand is met. The price of PV has decreased significantly over the past decade and can be considered (as BEopt and ZERH do-see Figure 4) to determine the point of diminishing returns on conservation measures. The space-conditioning criteria for passive buildings should 
reflect an economical balance between conservation and generation measures on the path to zero energy.

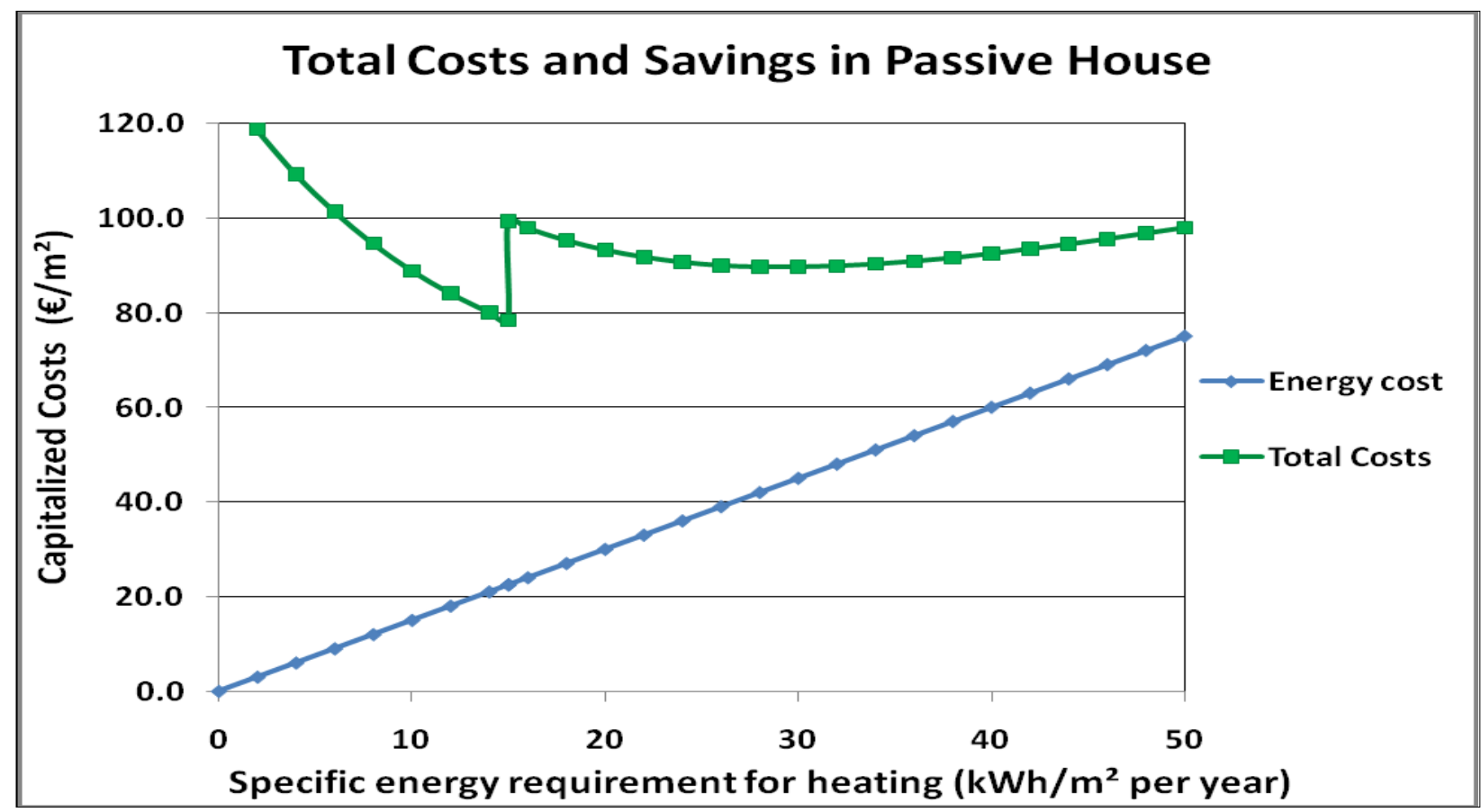

Figure 3. European cost graph

Source: Laustsen (2008), used with permission

Furthermore, PHI's definition of Passive House includes a $10 \mathrm{~W} / \mathrm{m}^{2}$ peak heat load, which translates into $15 \mathrm{kWh} / \mathrm{m}^{2} /$ year in the central European climate (PHI 2014). "Supply-air-heatingsufficient" everywhere implies that the building assemblies must be sized to a predefined and very small heating system instead of the other way around. The principle of "everybody has the same size minimized heating source" is a misapplication of the idea of a fair share. That principle properly applies to the total source energy but not to space conditioning. Instead, the fairness or leveling principle for space conditioning is economic competitiveness, which leads to varying energy measure performance criteria. Passive House can be defined as design for peak load $10 \mathrm{~W} / \mathrm{m}^{2}$ or by an economic optimum but not both and not everywhere at once.

Therefore, taking into account North American construction costs, energy cost parameters, the cost of PV, and different levels of investment required by climate will result in cost-competitive climate-specific space-conditioning criteria that are different than $10 \mathrm{~W} / \mathrm{m}^{2}$ or $15 \mathrm{kWh} / \mathrm{m}^{2} /$ year (3.17 Btu $/ \mathrm{ft}^{2} / \mathrm{h}$ or $4.75 \mathrm{kBtu} / \mathrm{ft}^{2} /$ year).

\subsubsection{Interaction of Criteria and Climate Misled Designers}

The relationship between degree-days and peak design temperature varies by climate; these variables are weakly correlated. Away from the coasts, peak design conditions are relatively harsh compared to degree-days. The annual heat demand criterion is almost always easier to meet than the peak load criterion and almost always used. Among current PHIUS-certified and precertified projects, the annual-demand route was taken $92 \%$ of the time outside the marine 
climate zones (3C and $4 \mathrm{C}$ ) and $42 \%$ of the time within the marine zones. Because the solar resource is generally greater in the United States than in central Europe, annual demand can be lowered with solar gains. This leads designers back toward overglazed designs, large interior temperature swings, and overheating issues.

A survey of certified and precertified projects showed that designers were led to rather high concentrations of glazing on south façades in colder climates (see Table 2).

Table 2. South Glazing Concentration by Zone, Certified and Precertified Projects

\begin{tabular}{c|c}
\hline Climate Zone & $\begin{array}{c}\text { Median South Window } \\
\text { Area Concentration }\end{array}$ \\
\hline $\mathbf{2}$ & $8 \%$ \\
$\mathbf{3}$ & $36 \%$ \\
$\mathbf{4}$ & $50 \%$ \\
$\mathbf{5}$ & $54 \%$ \\
$\mathbf{6}$ & $68 \%$ \\
$\mathbf{7}$ & $86 \%$ \\
\hline
\end{tabular}

\subsection{North American and European Climate Comparisons}

Peak heating load conditions are harsher-relative to annual demand — in much of North America than in Europe. Although the design for low peak load delivers the comfort and passivesurvivability benefits, the annual energy savings must repay that investment. Therefore, where the annual demand is low relative to the peak or the peak is harsh relative to the annual demand, the economics of a design for low peak load (e.g., "supply air heating sufficient") are even more challenging.

Table 3 through Table 7 show some examples of these patterns. PHI literature usually quotes $-10^{\circ} \mathrm{C} / 14^{\circ} \mathrm{F}$ as a peak load design temperature for central Europe; that corresponds to the ASHRAE 99.6\% design temperature for that region. The following is a comparison of climates on that basis (data taken from ASHRAE 2013).

On the East Coast of North America (Table 3), Boston (climate zone 5A) is similar to Frankfurt, Germany (climate zone 5) for annual demand as indicated by heating degree days (HDDs, highlighted in red) but has a harsher peak load condition. Peak load conditions comparable to Germany occur further south in Baltimore and New York (climate zone 4A, highlighted in blue).

Table 3. Design Temperatures and Degree Days, North America, Coastal, East

\begin{tabular}{|c|c|c|c|c|}
\hline Cities & $\begin{array}{l}\text { ASHRAE } 99.6 \% \\
\text { Design } \\
\text { Temperature }\left({ }^{\circ} \mathrm{F}\right)\end{array}$ & $\begin{array}{c}\text { ASHRAE 99\% } \\
\text { Design } \\
\text { Temperature }\left({ }^{\circ} \mathrm{F}\right)\end{array}$ & HDD65 & CDD65* \\
\hline Frankfurt, Germany (5) & -14.5 & -19.1 & $\overline{5,570}$ & 308 \\
\hline Boston, MA (5A) & & & 5,596 & 750 \\
\hline Baltimore, MD (4A) & 14.0 & 17 & 4,552 & 1261 \\
\hline New York, NY (4A) & 13.8 & 17.8 & I $4, \overline{8} 4 \overline{3}$ & 984 \\
\hline
\end{tabular}


The Northwest coast/Pacific Northwest has the peak-versus-annual relation closest to Europe (Table 4). The peak is milder at comparable annual demand. Seattle and Portland have milder peak and annual demands. Prince Rupert, which is further north, has a peak load that is comparable to Frankfurt.

Table 4. Design Temperatures and Degree Days, North America, Pacific Northwest

\begin{tabular}{|c|c|c|c|c|}
\hline Cities & $\begin{array}{l}\text { ASHRAE } 99.6 \% \\
\text { Design } \\
\text { Temperature }\left({ }^{\circ} \mathrm{F}\right)\end{array}$ & $\begin{array}{c}\text { ASHRAE 99\% } \\
\text { Design } \\
\text { Temperature }\left({ }^{\circ} \mathrm{F}\right)\end{array}$ & HDD65 & CDD65 \\
\hline Frankfurt, Germany (5) & $1-14.5$ & 19.1 & $\overline{5,570}$ & 308 \\
\hline Squamish, BC (5) & 18.3 & 22.4 & 5,987 & 115 \\
\hline Portland, OR (4C) & 25.2 & 29.5 & $\overline{4,214}$ & 433 \\
\hline Prince Rupert, BC (6) & 13.3 & 18.4 & 6,993 & 1 \\
\hline
\end{tabular}

In the midcontinental United States, places with similar HDDs to Germany have much harsher design temperatures. In the East and Midwest, one needs to go south almost to Nashville, Tennessee, to find comparably mild peak conditions (Table 5). That region's annual demand is substantially lower.

In the West the situation is the same - places with similar HDDs to Germany have much harsher design temperatures - but the design conditions moderate more slowly going south. One has to go south almost to Lubbock, Texas, for a comparably mild heating peak (Table 6). This far south, savings for cooling could also help the payback. Cooling-dominated places face a similar situation for a different reason: in the BEopt studies described in this report, the passive measures such as overhangs and thermal mass that are good for reducing peak cooling did not competitively deliver annual savings versus mechanical cooling. For example, overhangs cost $\$ 20 / \mathrm{ft}^{2}$ and for the price of one 10-foot overhang an air-to-air heat pump takes care of the entire cooling problem.

Table 5. Design Temperatures and Degree Days, United States, Midcontinent, East

\begin{tabular}{|c|c|c|c|c|}
\hline Cities & $\begin{array}{c}\text { ASHRAE } 99.6 \% \\
\text { Design } \\
\text { Temperature } \\
\left({ }^{\circ} \mathrm{F}\right)\end{array}$ & $\begin{array}{c}\text { A SHRAE } 99 \% \\
\text { Design } \\
\text { Temperature } \\
\left({ }^{\circ} \mathrm{F}\right)\end{array}$ & HDD65 & CDD65 \\
\hline Frankfurt, Germany (5) & $-14 . \overline{5}$ & 19.1 & $\overline{5,570}$ & 308 \\
\hline Pittsburgh, PA (5A) & 5.2 & 9.9 & 5,583 & 782 \\
\hline Indianapolis, IN (5A) & 2.0 & 8.1 & 5,272 & 1,087 \\
\hline Decatur, IL (5A) & 0.9 & 6.6 & 5,442 & 1,100 \\
\hline Louisville, KY (4A) & 10.2 & 15.9 & 4,109 & 1,572 \\
\hline Nashville, TN (4A) & 14.8 & 19.3 & 3,518 & 1,729 \\
\hline
\end{tabular}


Table 6. Design Temperatures and Degree Days, United States, Midcontinent, West-Central

\begin{tabular}{|c|c|c|c|c|}
\hline Cities & $\begin{array}{c}\text { ASHRAE } \\
\text { 99.6\% Design } \\
\text { Temperature } \\
\left({ }^{\circ} \mathrm{F}\right)\end{array}$ & $\begin{array}{c}\text { ASHRAE 99\% } \\
\text { Design } \\
\text { Temperature } \\
\left({ }^{\circ} \mathrm{F}\right) \\
\end{array}$ & HDD65 & CDD65 \\
\hline Frankfurt, Germany (5) & $=-14.5=-$ & 19.1 & $\overline{5}, \overline{570}$ & 308 \\
\hline Denver, CO (5B) & $0 . \overline{5}$ & 6.6 & 5,969 & 777 \\
\hline Kansas City, MO (4A) & 2.0 & 7.2 & 5,012 & 1,372 \\
\hline Amarillo, TX (4B) & 9.8 & 15.6 & 4,102 & 1,366 \\
\hline Lubbock, TX (3B) & $--\overline{15.9}--$ & 19.9 & 3,275 & 1,846 \\
\hline
\end{tabular}

In the Midwest north of Indianapolis conditions are even harsher. Madison, Wisconsin, has harsher peak conditions than Oslo, Norway (Table 7). Scandinavian Passive House certifiers moderated their peak load criterion to $15 \mathrm{~W} / \mathrm{m}^{2}\left(4.76 \mathrm{Btu} / \mathrm{h} / \mathrm{ft}^{2}\right)($ Jacobson 2013).

Table 7. Design Temperatures and Degree Days, United States, Midcontinent, North

\begin{tabular}{c|c|c|c|c}
\hline Cities & $\begin{array}{c}\text { ASHRAE 99.6\% } \\
\text { Design Temperature } \\
\left({ }^{\circ} \mathbf{F}\right)\end{array}$ & $\begin{array}{c}\text { ASHRAE 99\% } \\
\text { Design Temperature } \\
\left({ }^{\circ} \mathbf{F}\right)\end{array}$ & HDD65 & CDD65 \\
\hline Frankfurt, Germany (5) & 14.5 & 19.1 & 5,570 & 308 \\
Oslo, Norway (6) & -4.2 & 0.7 & 8,855 & 40 \\
Madison WI (6A) & -7.0 & 1.6 & 7,104 & 620 \\
\hline
\end{tabular}

In conclusion, the attempt to meet the European energy metrics in North American climates has forced solar-driven designs that tend to overheat and incur very high cost premiums for required envelope upgrades. Attempting to meet the annual criterion with higher R-values and less solar contribution - or attempting to reach the supply-air-heating sufficient peak load definition (10 $\mathrm{W} / \mathrm{m}^{2}$ ) — would drive the cost premium even higher. Both options would require considerable additional investment in the envelope ( 2 feet or more of typical R-4 wall insulation in very cold climates for smaller scale residential projects). Such investment at the current state of technology is neither practical nor cost-effective. The diminishing return for energy savings in such superinsulated walls that are required to meet the current criteria are also significant (see Figure 4).

Straube (2009) critiqued PHI's standard. Although this article contained some misunderstandings, its basic point was accurate: in ASHRAE climate zones 5 through 7 in North America the current European standard and its metrics are generally not economically justifiable. This study is a response to that and other similar unpublished critiques. 


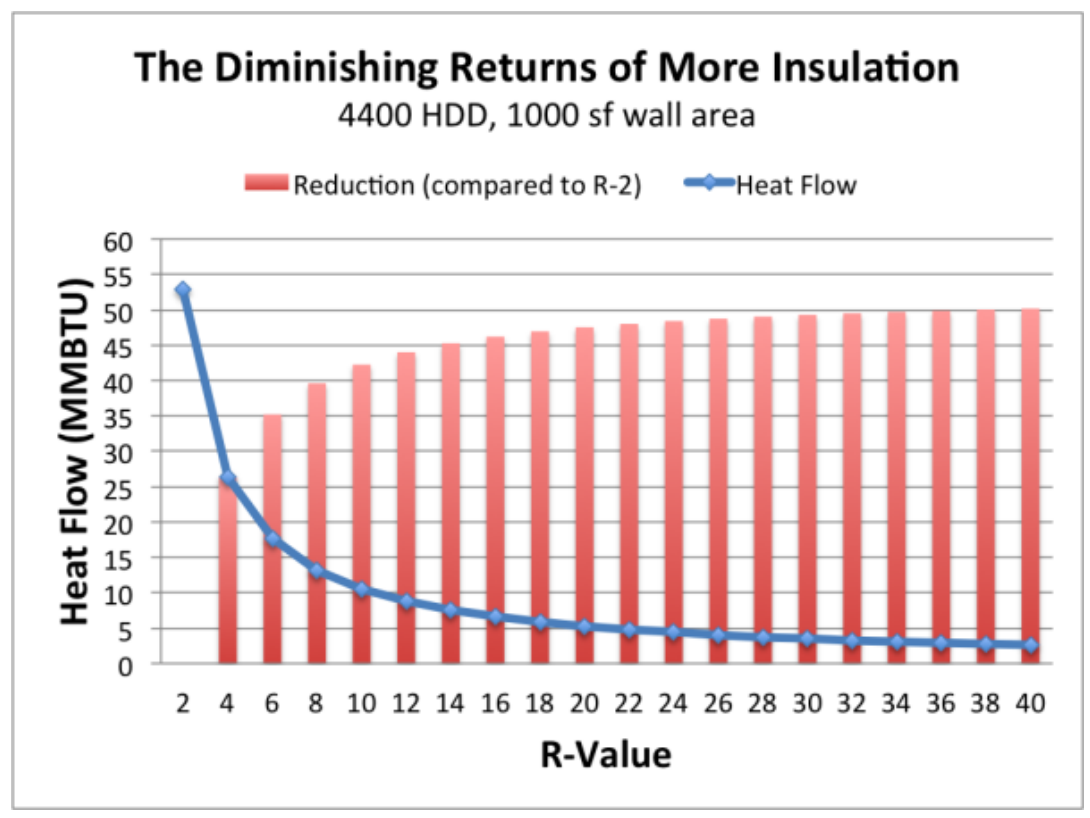

Figure 4. Diminishing returns of insulation in a 4,400 HDD climate

Source: www.energyvanguard.com, used with permission

\subsection{Illustrative Cases}

Nisson and Dutt's points in The Superinsulated Home Book about "Almost no architectural constraints" and "superinsulation does not require sacrifices" were about design. From their perspective an overheating problem means a design mistake has been made. Energy performance requirements represent a design constraint. Such constraints have to be chosen carefully according to climate so they do not inadvertently promote design mistakes such as the ones listed in Chiras (2005). PHIUS applied the European standard in Urbana, Illinois (zone 5A) and found it to be a significant constraint. The Fairview II house demonstration project featured R-60 walls, an R-100 ceiling, an R-70 slab, R-4.8 windows (installed R-value including installation thermal bridges), heat recovery ventilation, and $0.6 \mathrm{ACH} 50$ airtightness. Even though this package was much better than the first generation, the shape had to remain compact and $82 \%$ of the window area had to be concentrated on the south. The window area is also low-only $8.5 \%$ of the wall area.

This project has been monitored by Building America partner IBACOS; the detailed results were published as a DOE report as mentioned earlier. The Fairview house is $1,667 \mathrm{ft}^{2}$ gross (Figure 5). Designers of smaller or less compact houses such as the mini-B project (zone 4C) with $600 \mathrm{ft}^{2}$ gross and the Dublin House in Urbana Illinois (zone 5A), with 1,350 $\mathrm{ft}^{2}$ gross are forced even more strongly toward high south glazing to meet the energy metrics (see Figure 6 and Figure 7). 


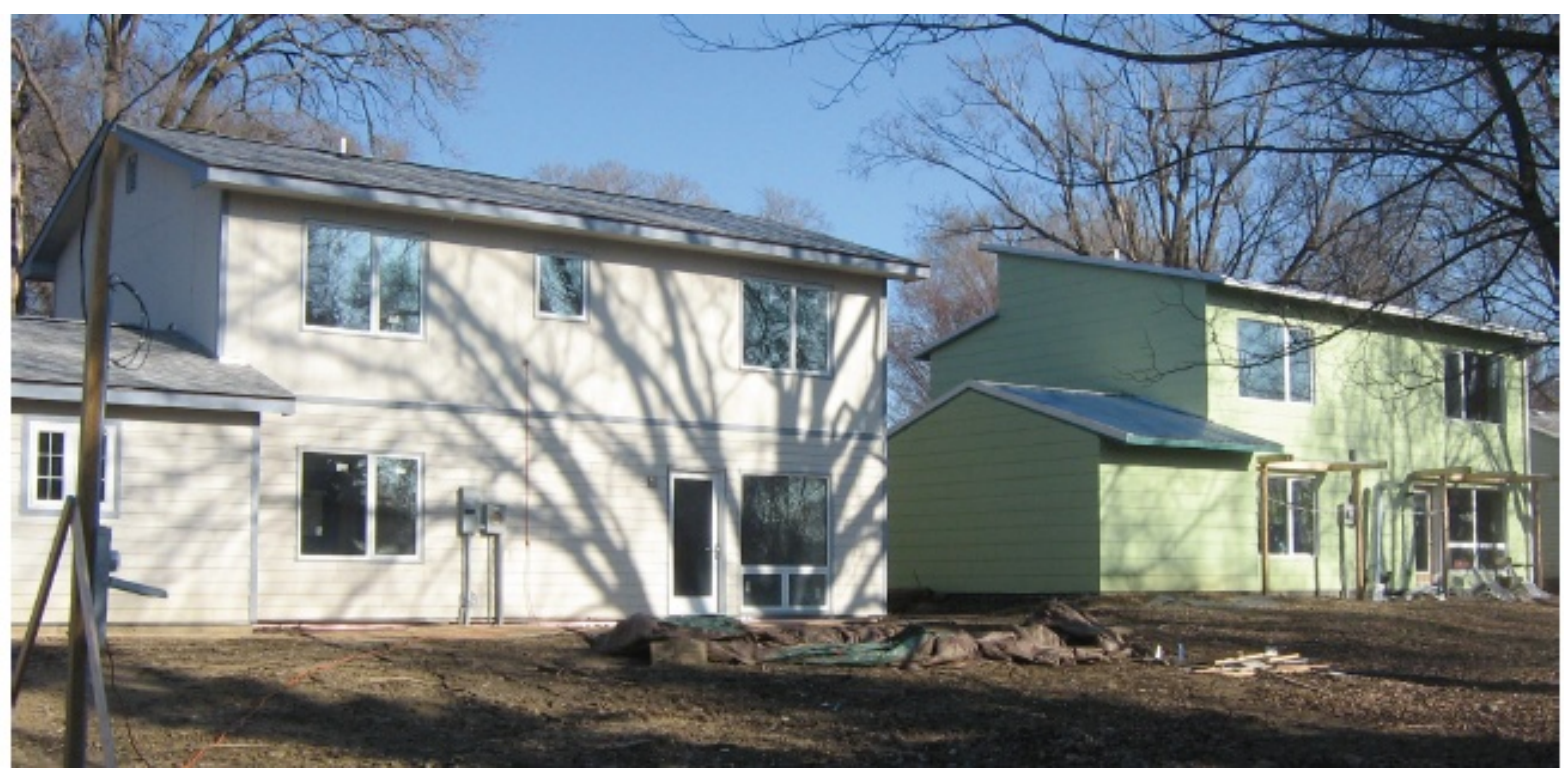

Figure 5. Fairview Houses I and II, 2007, Urbana, Illinois

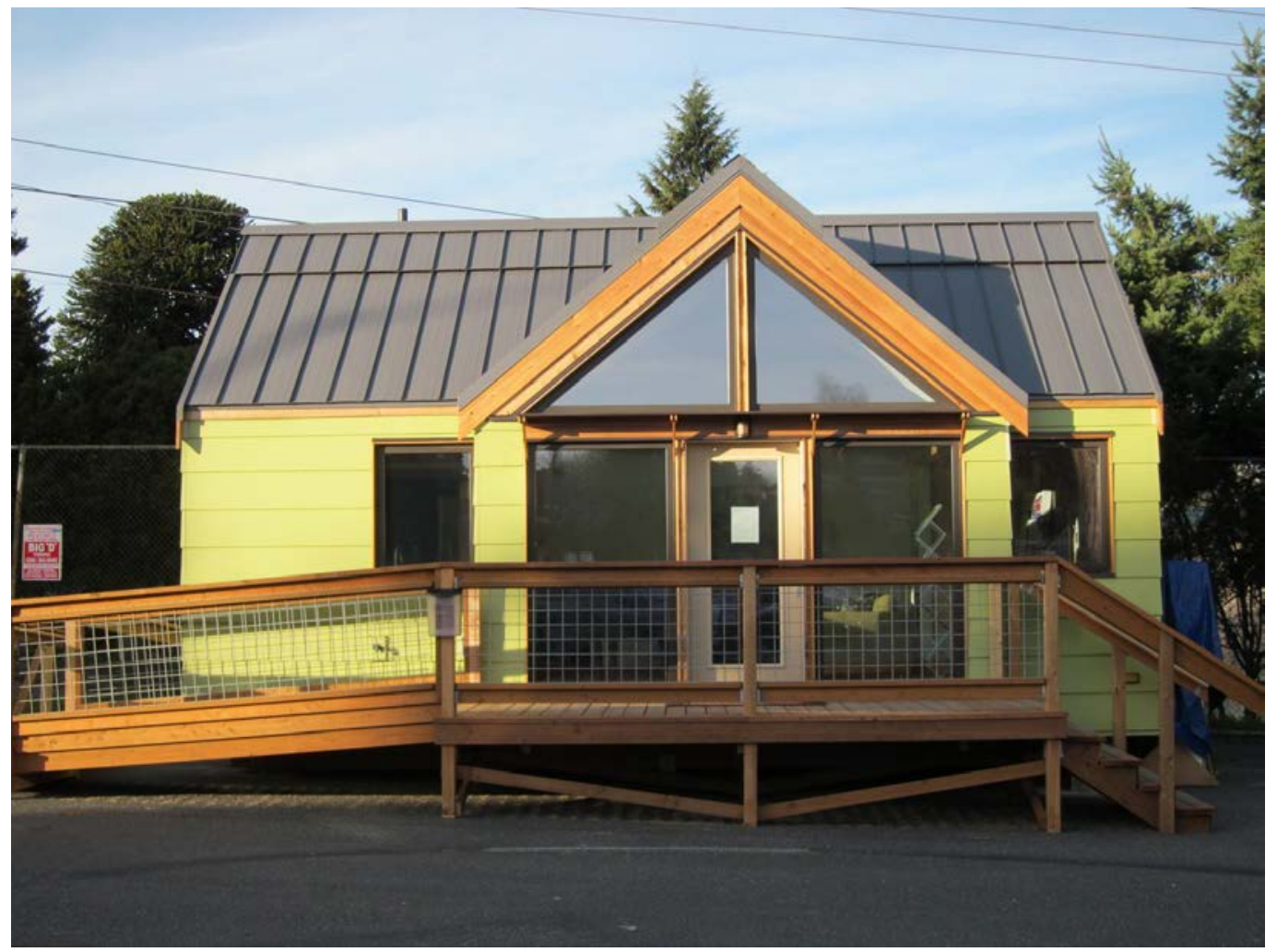

Figure 6. Mini B, 2010, Seattle, Washington 


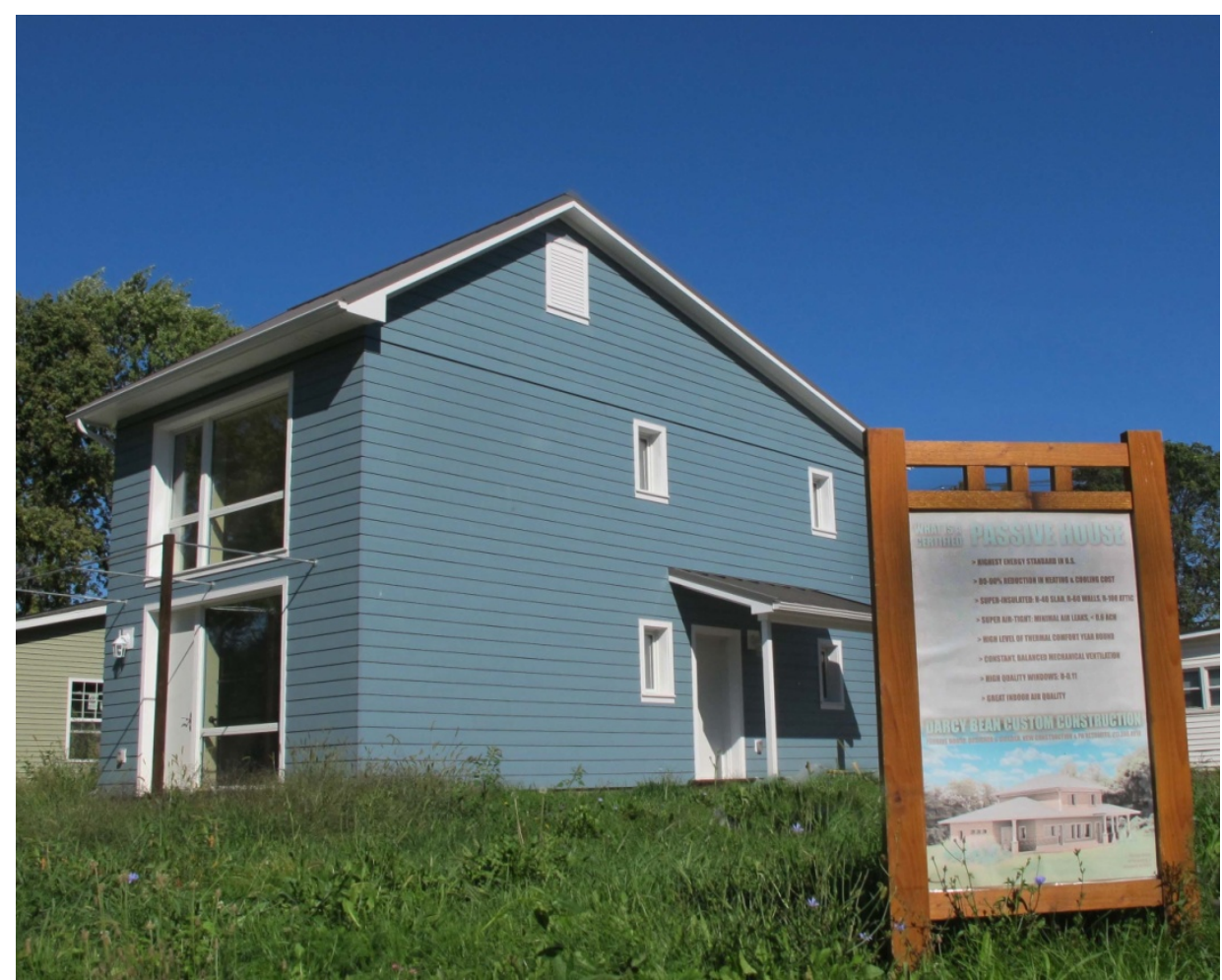

Figure 7. Dublin House, 2010, Urbana, Illinois

Another example case where lowering the annual heating demand with south glazing in a very cold climate led to comfort problems in winter and summer comes from PHIUS Technical Committee (TC) member Stuart Fix of Edmonton, Alberta (zone 7).

A modular homebuilder had set as his goal to build as close to zero energy as possible and chose the European metrics to guide the envelope design (see Figure 8). 


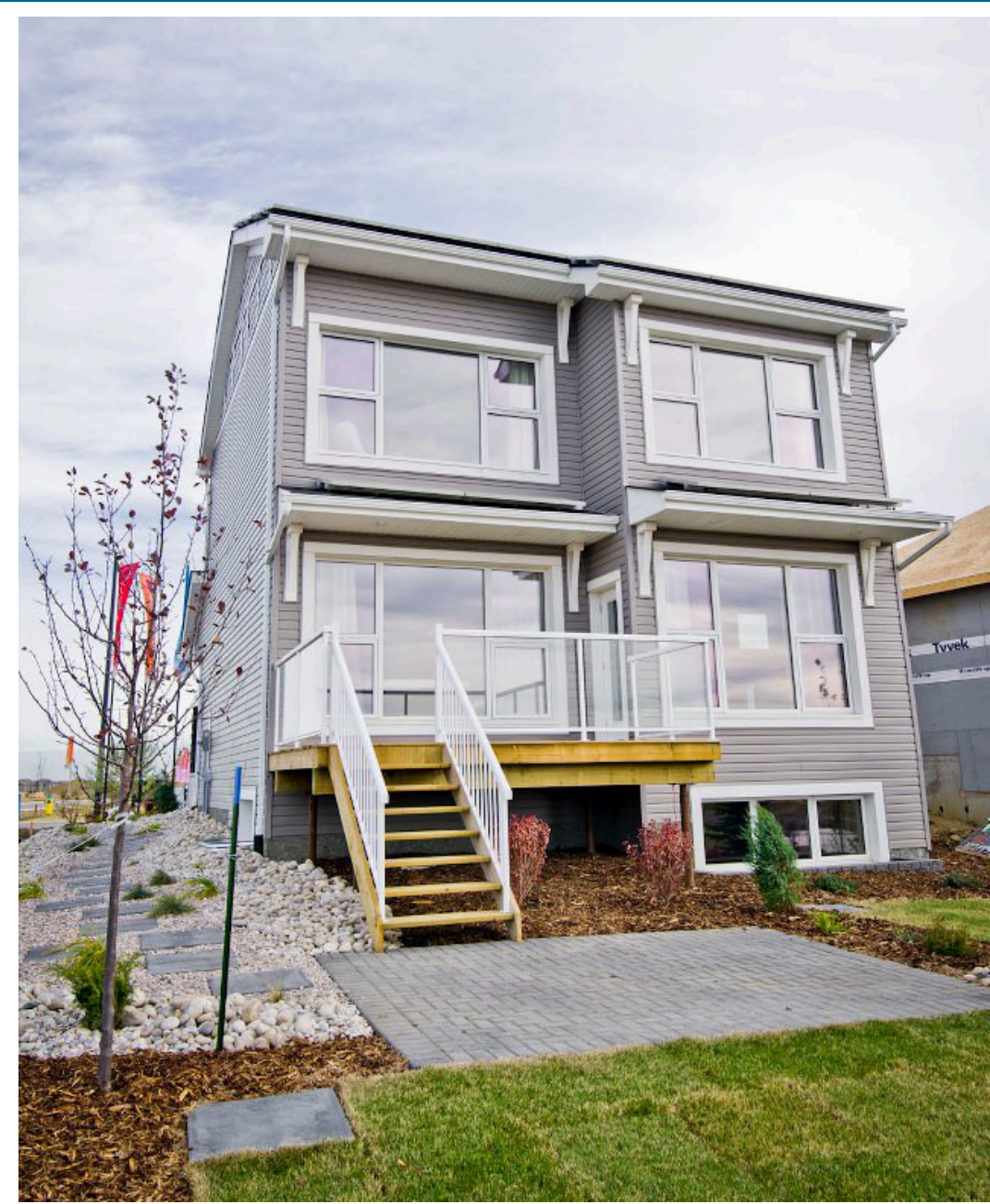

Figure 8. Modular passive home, Edmonton, Alberta

The Passive House Planning Package (PHPP) model used for this project showed no overheating issue. For comparison, one interior air temperature prediction was created with no natural ventilation and one was created with natural ventilation, using Integrated Environment Solutions Virtual Environment software (IESVE). (See Figure 9 and Figure 10.) The model predicts much less overheating if the natural ventilation is perfectly executed, but some incidents of inside temperatures higher than $77^{\circ} \mathrm{F}$ still occur. 


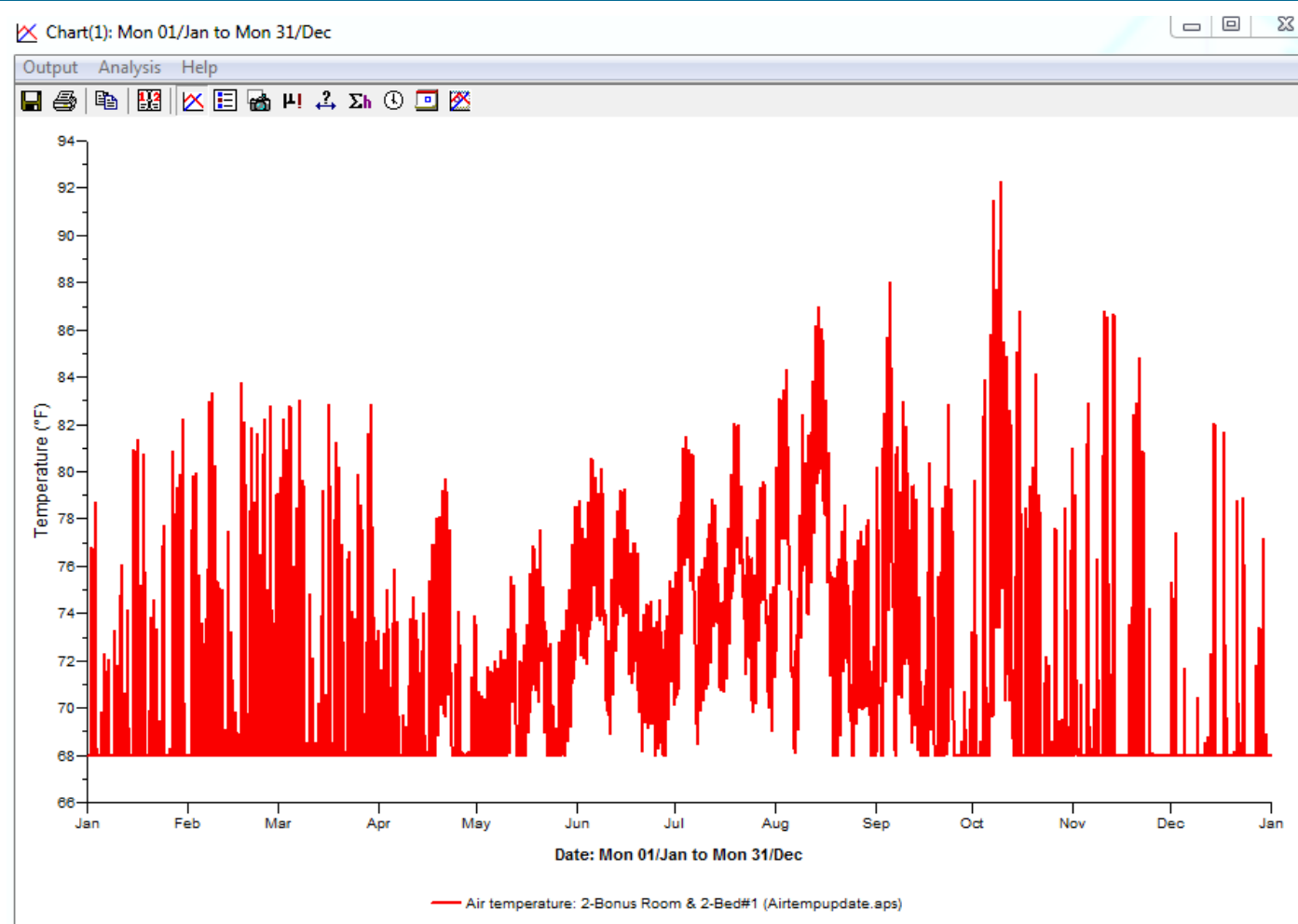

Figure 9. IESVE indoor thermal comfort prediction without natural ventilation

$\measuredangle$ Chart(1): Mon 01/Jan to Mon 31/Dec

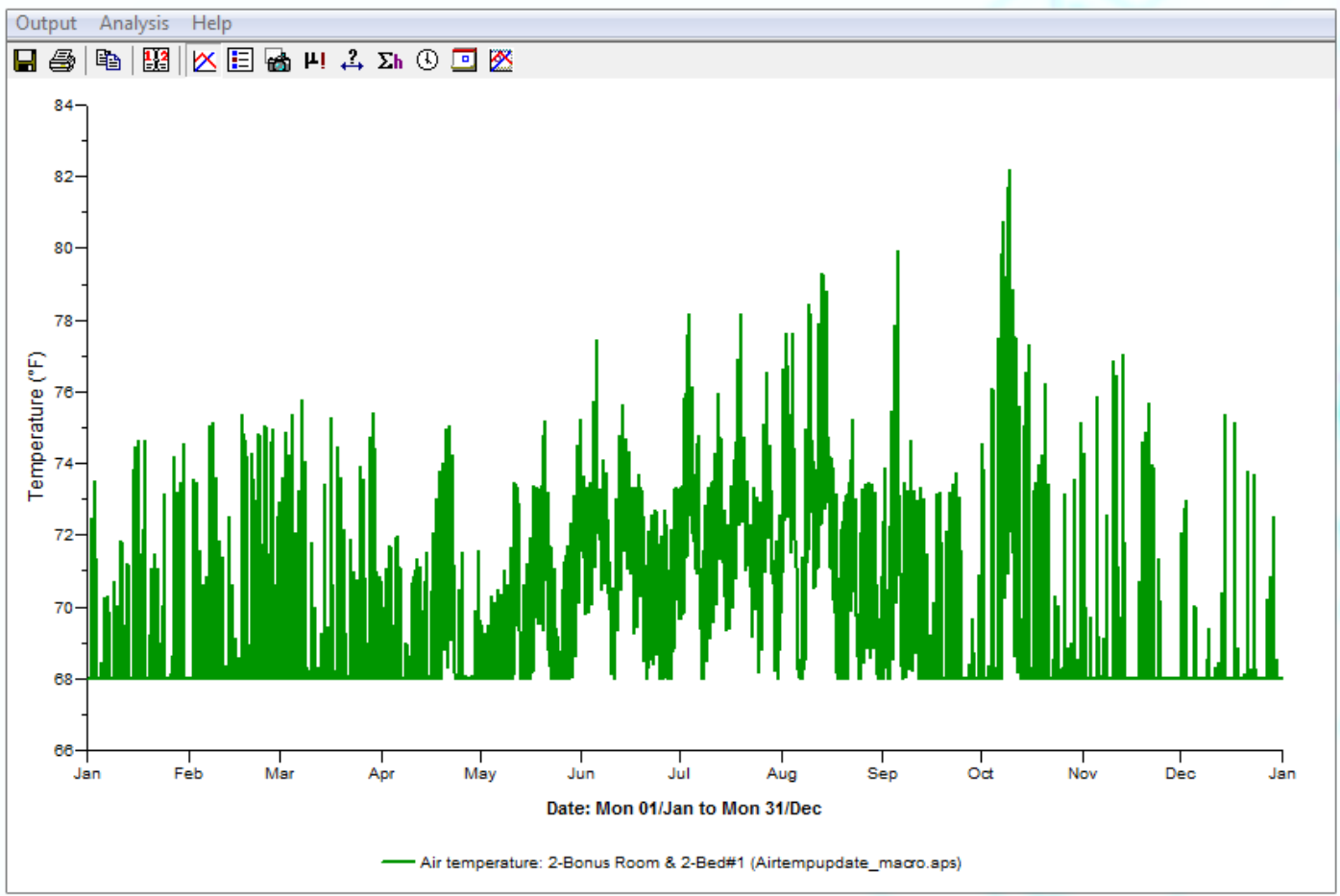

Figure 10. IESVE indoor thermal comfort prediction with natural ventilation, perfectly executed by occupants 
PHPP's predicted peak loads are 13,000 Btu/h heating and 1,000 Btu/h cooling. IESVE's ASHRAE heat balance method peak loads are 33,000 Btu/h heating and 22,000 Btu/h cooling. Electric heating was installed as shown in Table 8.

Table 8. Installed Heating Capacity for 3567 Claxton Crescent

\begin{tabular}{c|c|c|c}
\hline Room & Heat Supply & $\begin{array}{c}\text { Installed } \\
\text { Capacity } \\
\text { (Btu/h) }\end{array}$ & $\begin{array}{c}\text { Thermostat } \\
\text { Location }\end{array}$ \\
\hline $\begin{array}{c}\text { B-Great Room } \\
\text { 1-Nook/Kitchen }\end{array}$ & Ventilation air & 10,236 & $\begin{array}{c}\text { Main floor, south } \\
\text { mudroom wall }\end{array}$ \\
\hline $\begin{array}{c}\text { 2-Master Bedroom } \\
\text { 2-Bonus Room }\end{array}$ & In floor & 3,610 & $\begin{array}{c}\text { Mudroom wall } \\
\text { Half bath wall }\end{array}$ \\
\hline 1-Mudroom and Pantry & Radiant mirror & 2,900 & On mirror \\
\hline 1-Half Bathroom & In floor & 1,689 & Laundry room wall \\
\hline 1-Entry & & 2,150 & Ensuite wall \\
\hline 2-Laundry Room & Bathroom wall \\
\hline 2-Bathroom & Radiant whiteboard & 2,900 & On whiteboard \\
\hline 2-Bedroom \#2 & & 2,900 & On whiteboard \\
\hline 2-Bedroom \#3 & & 28,152 & \\
\hline
\end{tabular}

The mechanical engineer recommended point source heaters in all four south rooms, but the modular home company decided to rely on the heat recovery ventilator (HRV) supply's 3-kW heater to handle those loads. A 9,000-Btu/h air-source heat pump is situated in the second-floor hallway and distributes conditioned air over the stairs. It was installed for cooling.

The house was operated as a show home for 3 years, during which time its energy performance was monitored. The results showed that IES predicted loads and comfort conditions accurately; PHPP did not. With the current mechanicals comfort can be only marginally maintained year round if the house is operated manually. In the winter all electric heater thermostats have to be adjusted up manually during cold weather. In the summer, the air-source heat pump unit needs to run constantly, the house needs to be flushed nightly, and blinds need to be drawn when the sun is out and the house is still prone to overheating.

This show home experience provided the following lessons learned:

- The concept of supply air heating has been proven impossible in the very cold climate of Edmonton unless R-values are significantly higher than those used in this house. This is not cost-effective or pragmatic with current technology. Even then the home would require a very knowledgeable operator to maintain comfort.

- PHPP's simplified static calculations underpredict cooling and heating loads year round and cannot predict indoor thermal comfort accurately. It cannot be used to size the mechanical system in extreme climates. 
- A Passive House that has been designed using passive solar gains to meet the energy metrics may not perform well annually or during peak conditions. To meet the European criteria in Edmonton, passive solar gains must be maximized and the system must be sized using the ASHRAE loads and a significant cooling system installed. The correct design decision to optimize thermal comfort would be to stay away from high solar gains and go for higher R-value instead; however, peak loads and annual demand criteria are so aggressive that this strategy will not get the project certified.

Conclusion: The current German-derived energy criteria are set too tight for extreme climates and in practice incentivize the wrong design decisions. This leads to undersized systems and thermal comfort issues. The criteria would be more effective if they were set at a less-aggressive annual demand that would not force extreme solar gains or overinvestment at significant diminishing returns in the envelope.

\subsection{Synthesizing Program Characteristics}

The baselines for this study's efforts are:

- The original low-peak-load approach brought forward by the North American Passive House pioneers

- The European guiding energy metrics applied by the current PHIUS+/ZERH program

- Cost data and optimization algorithms used by BEopt.

This study drew on aspects of all three approaches and synthesized them into a climate-specific passive building standard that will guide the design process toward an exceptional level of energy efficiency, cost-competitiveness, and thermal comfort for the next-generation ZERH.

\subsection{Aspects To Retain}

The proposed next-generation standard is performance-based; that is, it is based mostly on modeled performance as opposed to a prescriptive or an outcome-based approach. The standard aims to encourage conservation measures and low-load design by first specifying spaceconditioning criteria that have to be met before renewable energy can be applied to reduce energy consumption in buildings to zero. The new standard is proposed to be pass/fail.

The same criteria would apply to all types and sizes of buildings. Following a similar methodology as proposed for this study might be useful in the future to ramify commercial or multifamily specific standards. For now, the studies are predicated on housing that is typical for the North American market (i.e., the three-bedroom single-family house). The resulting criteria can reasonably be applied to all building types because more materials-efficient forms of housing such as multifamily units or larger commercial buildings will more easily meet the criteria; less materials-efficient forms such as detached "tiny houses" will have more difficulty. Such an approach therefore effectively rewards and encourages more efficient forms of building in that sense. The proposed standard maintains the three-pillar structure: limits on the space conditioning loads, a limit on the total source energy, and an airtightness requirement.

The first pillar - a set of space-conditioning criteria — limits the energy use "downstream" of the heating and cooling equipment (as opposed to the site energy supplied to the equipment). That is, the heating or cooling that the system must deliver is limited. Therefore, criteria must be met with passive measures first - including conservation measures such as insulation, air-sealing, 
overhangs, and direct solar gains. The criteria can also be met using low-grade energy measures that can make low-temperature heat energy available through very small mechanical energy inputs. Examples are fan- and pump-assisted devices such as HRVs with heat/humidity recovery, earth air tubes, brine loops, and whole-house fans. (See Appendix F for an inclusive list of passive measures and low-grade energy measures.)

The second criterion is the limit on total source energy - space-conditioning energy plus all the other energy uses in the building such as appliances, lights, and hot water. Efficient equipment makes its contribution in these applications.

The third criterion is the mandatory level of airtightness. Limiting ventilation heat losses through leaks in the envelope improves the building's overall energy performance and long-term durability.

\subsection{Aspects of the Current Passive Standard To Amend}

For each of the three pillars, the studies were compartmentalized according to the appropriate underlying principle.

\subsubsection{Space-Conditioning Criteria}

By 2011 it became clear that one-size-fits-all space-conditioning criteria needed a significant climate-dependent adjustment if the standard were to deliver deep energy savings and comfort cost-optimally (or at least cost-competitively) to a broader market in North America. A new framework for space-conditioning criteria was needed.

The space-conditioning criteria follow from considering the economic and cost-competitive levels of investment in passive measures by climate. (The cost of PV and other renewable energy sources is now part of the equation.) In the context of building design, space-conditioning criteria drive investment in passive and low-grade-energy measures first.

For this study economic optimization was chosen (instead of designing for a set peak load) as the basic strategy for setting the space-conditioning criteria for deciding "how low to go" in reducing the heating and cooling loads. Setting the space-conditioning criteria is the main objective of this study. As discussed in Section 2, that optimization was performed under constraints to ensure that other benefits were not lost. (For example, to maintain daylighting the window area as a percentage of the wall area is fixed at the BA benchmark $15 \%$ and the window U-values have strict minimums to ensure winter comfort.)

To ensure that enough energy is saved and the benefits of low peak loads are preserved, a "bothand" set of criteria has been proposed. In other words, the TC proposes to set limits on annual heating demand and peak heating load and on annual cooling demand and peak cooling load. The criteria appear in Eq. 1:

Annual heating demand $<\mathrm{A}$, Annual cooling demand (sensible + latent) $<\mathrm{B}$,

Peak heating load $<\mathrm{C}$, and

Peak cooling load $<$ D 
Where the targets $\mathrm{A}, \mathrm{B}, \mathrm{C}$, and D vary by climate.

The idea is to keep designs balanced and to prevent biasing the design solution in a way that would have negative consequences for thermal comfort or cost-competitiveness.

In preliminary work, one proposal was to identify criteria zone-by-zone for the ASHRAE/DOE climate zones. This could obviously lead to issues in borderline regions. A continuous-function approach was preferred to motivate the development of a simplified formula to generate compliance values that are specific to each location.

The central questions are:

- How much investment in passive measures is reasonable from a cost perspective?

- How low should the load criteria be set?

Although PHI claims that the "economic optimum" occurs at $10 \mathrm{~W} / \mathrm{m}^{2}$ peak heat load or the 4.75 $\mathrm{kBtu} / \mathrm{ft}^{2} /$ year annual heating demand everywhere in the world (Grove-Smith and Pfluger 2013), practice has proved otherwise.

BEopt provides a tool to cost optimize by climate. Clearly, cost is a moving target over time. Nevertheless, it can be dealt with by revising the standard every $3-5$ years, much like the building code cycle.

\subsubsection{Source Energy Criterion}

The criterion based on source energy aligns in principle with the BA and National Renewable Energy Laboratory zero energy goals. Source energy serves well as a proxy for the global environmental impact of carbon dioxide $\left(\mathrm{CO}_{2}\right)$ emissions from fossil fuels. In the context of building design, a source energy criterion incents efficient equipment for heating, cooling, and all other purposes.

The source energy limit follows from considering the global impact of the type of energy used in building operation (mainly $\mathrm{CO}_{2}$ but also nuclear waste). Motivation for the source energy limit comes from the Intergovernmental Panel on Climate Change (IPCC), which estimates that to have a $66 \%$ chance of a less than $2{ }^{\circ} \mathrm{C}$ global temperature rise, all-time total emissions should stay lower than 800 gigatons $\mathrm{CO}_{2}$ equivalent. Some uncertainty remains about how much has been emitted so far (IPCC 2013). A recent update states: "Without additional mitigation efforts beyond those in place today, and even with adaptation, warming by the end of the 21 st century will lead to high to very high risk of severe, widespread, and irreversible impacts globally" (IPCC 2014).

The perspective on source energy presented here, though aligned in principle, is different than the one for which BEopt is braced. BEopt's implied perspective is that source energy matters most; economic analysis determines the level of investment in conservation measures (whether active or passive) versus PV.

The logic of the criterion proposed here is that space-conditioning energy and investment in passive measures are subject to economics but total source energy is not-it is subject to a cap as outlined in the IPCC report. This is consistent with fair-share-of-the-atmosphere considerations. The atmosphere can be regarded as the ultimate commons; $\mathrm{CO}_{2}$ emissions disperse around the 
world and affect everyone. In reconsidering source energy, the PHIUS TC stayed within this framework but did look into whether relaxing the limit would be justified, as follows:

An equal allocation of the remaining emission budget to each living person that assumes a linear glide path to zero emissions in 2050 gives a range of 2.2-3.8 tons/person/year for all purposes. By way of contrast, International Energy Agency data show the United States running at about 17 tons/person/year for all purposes (see Table 9).

Table 9. $\mathrm{CO}_{2}$ Fair-Share Numbers

\begin{tabular}{|c|c|c|}
\hline Tons per Person per Year & Today & 2050 \\
\hline $\begin{array}{l}\text { U.S. Emissions, All Purposes, Randers (2012) }\left(2.8^{\circ} \mathrm{C} \text { rise by }\right. \\
\text { 2050) }\end{array}$ & 18 & 9.4 \\
\hline International Energy Agency $2^{\circ} \mathrm{C}$ Scenario, USA & 17 & 3.8 \\
\hline $\begin{array}{l}\text { Building Sector Portion (Assuming 28\%-33\% of Total), } \\
\text { Randers (2012) }\end{array}$ & 5.5 & 2.9 \\
\hline $\begin{array}{c}\text { International Energy Agency, Building Sector, if All Savings } \\
\text { from New Construction }\end{array}$ & 5.2 & 3.2 \\
\hline $\begin{array}{c}\text { Equal Share of Remainder of IPCC Budget } 800 \mathrm{Gt} \text {, High } \\
\text { Estimate, Linear Glide Path to Zero in } 2050 \text {, No Budget for } \\
\text { the Unborn }\end{array}$ & 3.8 & 0 \\
\hline Ditto, Low Estimate. & 2.2 & 0 \\
\hline Building Sector Share, High & 1.1 & 0 \\
\hline Building Sector Share, Low & 0.7 & \\
\hline Equivalent of $120 \mathrm{kWh} / \mathrm{m}^{2}$ Source Energy Limit & 1.0 & \\
\hline
\end{tabular}

Giving the building sector its typical $28 \%-33 \%$ share of the total 2.2 - to 3.8 -ton/person/year leaves $0.7-1.1$ ton/person/year for the building sector. That is approximately where the current limit is in PHI's standard; e.g., $120 \mathrm{kWh} / \mathrm{m}^{2} /$ year converts to 1 ton/person/year at a standard occupancy of $35 \mathrm{~m}^{2} /$ person. The bottom line is that the current source energy criterion cannot be justifiably relaxed.

This source energy standard is aggressive from the International Energy Agency's point of view. Its $2^{\circ} \mathrm{C}$ scenarios do not count on much reduction from the building sector in the developed world because the building stock has low turnover. For the United States, the agency pictures the main opportunity as decarbonization of the electricity grid by large-scale deployment of renewables.

The TC agreed on the following protocol relating to source energy calculation:

The source energy factor for grid electricity mix is 3.16 (consistent with the IECC). The U.S. electricity grid has source energy factors of 2.374-3.549 depending on the major interconnect region; the national average is 3.138 (Deru and Torcellini 2007, Table B-2). The national average can be used for simplicity and for a level playing field.

Arguments have been brought forward to calculate the source energy factor for projects locally. That approach was rejected. If that path had been followed in some areas such as the Pacific Northwest (where abundant hydro energy keeps the source energy factor low), it would be too easy-cost-effective energy savings would be left on the table. In other areas where the grid is 
all coal-based and that have a very high source energy factor the criterion could not be met without adding solar thermal systems. Also, accounting for the effect of a utility's imports from or exports to other utilities with different source factors would be complicated. Only at the scale of the major interconnected regions or larger does that problem go away.

For residential projects a per-person budget based on a fair share of the atmosphere consideration is appropriate. Occupancy is therefore taken to be the number of bedrooms plus one per dwelling unit - as in RESNET. The limit for nonresidential projects such as schools and offices would stay at $120 \mathrm{kWh} / \mathrm{m}^{2} /$ year $\left(38.1 \mathrm{kBtu} / \mathrm{ft}^{2} /\right.$ year $)$. Additional allowance can be determined case by case for process loads in commercial buildings.

For residential projects the defaults for lighting and plug loads would use $80 \%$ of RESNET levels. Specifically, these levels refer to clause 303.4.1.7, subclauses .1, .2.2, .2.3, and .2.4 of the Mortgage Industry National Home Energy Rating Systems Standards, January 1, 2013 (RESNET 2013). An example is shown in Table 10. For this calculation, the conditioned floor area is the exterior-dimension floor area of the conditioned spaces per RESNET rules. RESNET lighting and plug load assumptions are about six times higher than the defaults assumed under the PHI certification protocol but lower than assumed for the BA benchmark home.

Table 10. Lighting and Plug Loads Example Calculation, Standard-Adaptation Study Building

\begin{tabular}{|c|c|c|c|}
\hline & & $\begin{array}{c}\text { Mortgage Industry } \\
\text { National Home Energy } \\
\text { Rating Systems Standards, } \\
\text { January 1, 2013 Clause } \\
\end{array}$ & $80 \%$ \\
\hline Conditioned Floor Area $\left(\mathrm{ft}^{2}\right)$ & 2,080 & & \\
\hline Number of Bedrooms & 3 & & \\
\hline $\begin{array}{l}\text { Televisions and Miscellaneous } \\
\text { Electricity Loads (kWh/yr) }\end{array}$ & 2,513 & 303.4.1.7.1 & 2,010 \\
\hline $\begin{array}{l}\text { High-Efficiency Lighting in } \\
\text { Qualifying Interior Fixtures (\%) }\end{array}$ & 100 & & \\
\hline Interior Lighting (kWh/yr) & 882 & 303.4.1.7.2.2 & 706 \\
\hline $\begin{array}{l}\text { High-Efficiency Lighting in } \\
\text { Qualifying Exterior Fixtures (\%) }\end{array}$ & 100 & & \\
\hline Exterior Lighting (kWh/yr) & 51 & 303.4.1.7.2.3 & 41 \\
\hline $\begin{array}{c}\text { High-Efficiency Lighting in } \\
\text { Qualifying Garage Fixtures (\%) }\end{array}$ & 100 & & \\
\hline Garage Lighting (kWh/yr) & 25 & 303.4.1.7.2.4 & 21 \\
\hline Lighting Total & 958 & & \\
\hline
\end{tabular}

RESNET defaults for energy use by "televisions and miscellaneous electric loads" are substantially higher than the current equivalent baseline defaults for "consumer electronics and small appliances" currently assumed in the PHPP. The same goes for lighting; BA formulas give higher numbers yet. The formulas work a bit differently in that the baseline formulas are strictly per person. RESNET uses a combination of per-person and per-square foot terms.

The low PHPP defaults are grossly unrealistic; this discrepancy must be fixed. One objection to the proposal that set the defaults at higher levels has been that lower default assumptions 
encourage lower usage. But setting a design standard at low levels does not mean that it has any power over the occupants. It would be different in an outcome-based program; however, in a performance standard the effect is reversed because it gives the designers the false impression that they have considerable latitude with source energy.

Another objection has been that the resulting higher internal heat gains weaken the incentive to invest in the shell to reduce heating demand. In heating-dominated climates, that is indeed the case. But credible values for the current reality and assumptions that are as accurate as possible should be used. Unrealistic assumptions can lead to significant errors in the predicted performance of annual demands and peak loads. Measured results that are currently at hand from earlier projects show this discrepancy and weaken the credibility of the program and the claimed accuracy of the model. For example, in a house built in 2009 in Salem, Oregon, the overall measured consumption was higher than modeled when the European defaults are assumed (see Table 10 and Figure 11). The right-hand column in Figure 11 indicates the certification limits. Higher plug loads and associated internal gains than those assumed in the model caused the discrepancy and also led to a significant unanticipated cooling demand in this Pacific Northwest climate.

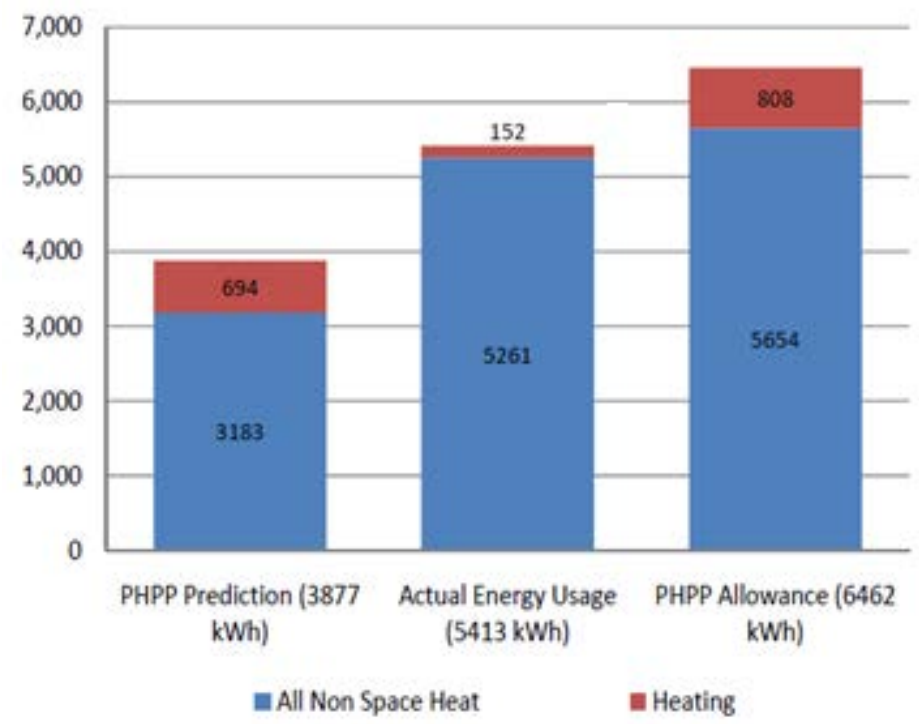

Figure 11. Measured performance data for the passive home in Salem, Oregon, first-year billing analysis

Source: Ecotope (2010), used with permission

PHIUS certification staff experimented with allowing detailed lighting and plug load itemization for residential projects but advises that this be discontinued. Such itemization is difficult to verify and allows too much manipulation by the planner that in the end are the homeowners' choices (for nonresidential buildings, lighting and miscellaneous loads are more plausibly under the designers' control). 
Such an increase in residential lighting and plug load defaults is a large change that makes it considerably harder to meet the source energy target. Straightforward conversion of the 120 $\mathrm{kWh} / \mathrm{m}^{2} /$ year limit times $35 \mathrm{~m}^{2} /$ person standard occupancy would give a limit of 4,200 $\mathrm{kWh} /$ person/year. A review of previously certified projects showed a median source energy design for 4,100 kWh/person/year; however, with lighting and plug load defaults adjusted to RESNET levels the median would have been almost $6,600 \mathrm{kWh} /$ person/year. (Wright and Klingenberg 2013) Therefore, as a shock absorber, the source energy limit should be temporarily relieved to $6,200 \mathrm{kWh} /$ person/year and return to 4,200 by a date to be determined.

Also, in the current passive building energy planning software/methodology, the only renewable energy that counts toward reducing source energy is solar thermal. The reasoning has been that the energy produced by such a system is primarily used on site and not exported in any way. The TC agreed to put other renewable generation on the same footing if it is used as it is produced. Therefore, an estimate of coincident production and use of energy from renewable energy systems (such as PV) may be included in the calculation similarly to the way solar thermal systems are currently treated; that is, the limit would apply to source energy consumption net of that generation. Dynamic simulations with hourly time resolution are acceptable at this time. For PV specifically, an example utilization curve is shown in Figure 12.

$\begin{array}{ll}\text { PV/Total } & \text { Live utilization } \\ 0 & 1 \\ 0.09 & 1 \\ 0.19 & 0.96 \\ 0.38 & 0.74 \\ 0.95 & 0.39 \\ 1.5 & 0.27\end{array}$

Chicago climate Array $\mathrm{S}$ facing at latitude tilt

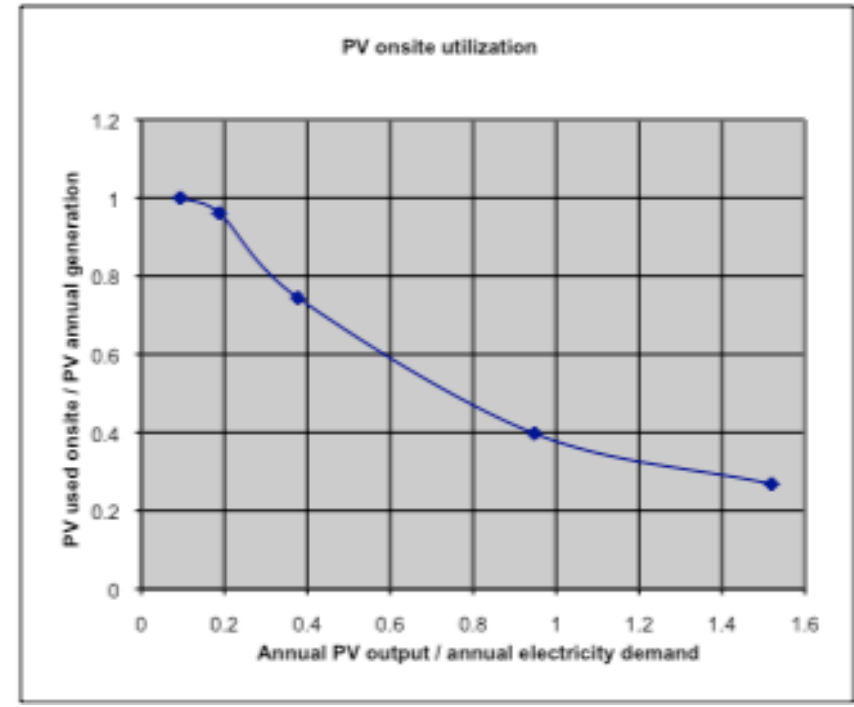

Figure 12. Example estimate of coincident production and use ("live utilization") of PV electricity

\subsection{Occupant Behavior Summary}

In the space-conditioning studies discussed in Section 2, occupant behavior is standardized as in regular project planning. Some of the design constraints in the optimization studies assume people can:

- Tolerate $68^{\circ} \mathrm{F}$ in winter and $77^{\circ} \mathrm{F}$ in summer.

- Operate windows for natural ventilation cooling.

- Put up solar screens seasonally.

- Use lighting and plug loads at levels that equal $80 \%$ of RESNET (less than BA). 
- Use hot water per BA assumptions (approximately 50\% higher use than PHPP).

- Have exhaust range hoods and dryers per BA House Simulation Protocols.

\subsection{Airtightness}

The airtightness requirement follows from the consideration of building durability and mold risk. In the context of building design, an airtightness criterion incents investment in reducing energy losses via envelope leakage and in greater durability of the envelope components.

The air-leakage study that was conducted by PHIUS TC members presents the scientific argument about the appropriate level of airtightness to set as a standard. The airtightness study is beyond the scope of this report, which focuses on space conditioning.

\subsection{Other Notable Amendments}

A square-foot-based energy metric has to be based on a specific reference floor area, which needs to be carefully defined because its rules may influence the design. A reference area should be chosen that is consistent with the real estate or construction industry for a meaningful comparison of energy metric results between diverse building types.

The TC agreed on a simplified reference floor area definition (conditioned floor area by internal dimensions or iCFA): the floor area is measured on the interior dimensions of the passive building thermal envelope, drywall-to-drywall, where ceilings are at least 7 feet high. This definition specifically includes stairs, interior partitions, baseboards, and cabinets. It specifically excludes open-to-below spaces. This definition is a compromise between the exterior-dimension reference floor area typically used for energy use intensity metrics in the United States and the effort to encourage the efficient use of high-quality spaces inside the thermal envelope. The TC agreed that exterior walls should not be included. 


\section{Methodology}

\subsection{Economic Optimization Studies-Overview}

A study building was calculated for approximately 100 locations. BEopt was used to compute the series of optimal upgrade packages from code minimum to maximum savings. The cost optimization was done under constraints, notably:

- Assumed a consistent airtightness level

- Assumed window upgrades for $60^{\circ} \mathrm{F}$ minimum interior surface temperature, climatespecific $^{1}$

- Educated occupants as noted in Section 1.9.

A judgment call was made about the point of deepest energy savings that are cost-competitively feasible - location by location - to ensure the lowest feasible peak load conditions. Then the heating demand, cooling demand, peak heating load, and peak cooling load at that point were noted and statistical models were fitted to the demands and peak loads so that target values could be generated for any location from site parameters such as degree-days and design temperatures.

For Phase 1, economic studies were conducted using BEopt version 2.2.0.1. As described by Christensen et al. (2005, 2006), its basic purpose is to identify optimal building designs to achieve zero energy. That optimal path appears as a U- or "swoosh"-shaped curve on a plot of annualized energy-related costs (mortgage + utilities) versus energy savings. The conceptual plot is shown in Figure 13.

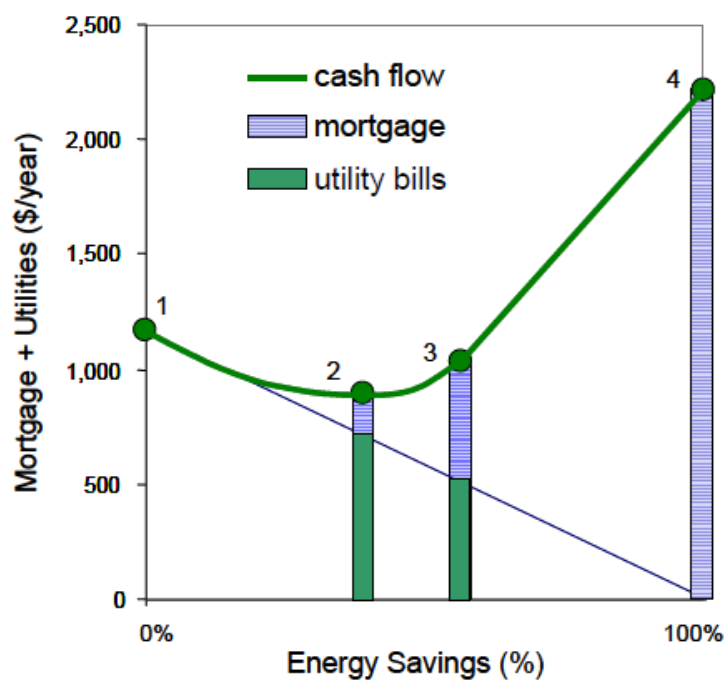

Figure 13. Conceptual plot of the path to zero energy

At the left side of the figure, the reference building has high utility bills but no added finance cost for energy-saving or energy-generating upgrades. On the right side, the zero upgraded building design has no energy bill but a higher mortgage payment. Near the middle is a cost-

\footnotetext{
${ }^{1}$ Calculated assuming interior air temperature of $68^{\circ} \mathrm{F}$, air film resistance of $0.74 \mathrm{~h} / \mathrm{ft}^{2} /{ }^{\circ} \mathrm{F} / \mathrm{Btu}$, and outside temperature at the 12-hour mean minimum for the climate location.
} 
optimal set of upgrades (point 2). At point 3, generating energy with PV becomes more costeffective than conservation. As described by Christensen et al. (2005):

"The optimal path is defined as the lower bound of results from all possible building designs. ... At each step along the path, BEopt runs individual simulations for all user-selected options and searches for the most cost-effective combination of options."

BEopt brings together a state-of-the-art dynamic simulation engine (EnergyPlus), a full-featured life cycle cost calculation module, an optimization algorithm, and a cost database. Although the National Renewable Energy Laboratory's construction cost database is not intended for projectspecific analysis, it is largely appropriate for relative comparison to a benchmark; some cost overrides were done on a few key measures.

The basic procedure is to:

1. Set up a model of a canonical/touchstone building of a fixed size and shape.

2. Give the optimizer a number of parameters to adjust (i.e., add energy-saving measures)

3. Run an optimization.

In optimization mode, BEopt determines a life cycle cost-optimal configuration for a series of progressively deeper energy savings (site or source), picks the lowest hanging fruit first, then the next lowest, and so on. The criteria for the standard are set by looking at the annual demands and peak loads in the study building for a point "near" the minimum cost and setting the criteria at those levels for that climate. The exercise is then repeated for other climate locations.

The approach is similar to that of Kruger (2012). The main difference from his work is that this study dispenses with the calibration to German cost (substituting North American expert judgment, which Kruger implied would have been preferable anyway), constrains the optimizer differently, and keeps the heating and cooling demands separate when setting the criteria and limiting peak loads.

To support interpolation or the fitting of continuous-function rules for the criteria, the team determined that at least 100 locations would be needed (a 5-factor curve fit with 10 two-way interactions and 5 quadratic terms has 20 adjustable parameters). Economic analyses were run on the 111 locations for which WUFI data are available (which support dynamic simulations for comfort verification and hygrothermal checks). Figure 14 shows a map of these locations.

\subsection{The Study Building and Other Constant Factors}

A single-family detached house was chosen for the studies because it is the predominant housing type in the United States. The performance criteria are based on this average-size single-family home (the current standard is similarly based on a single-family townhouse end unit) (Schneiders et al. 2012). 


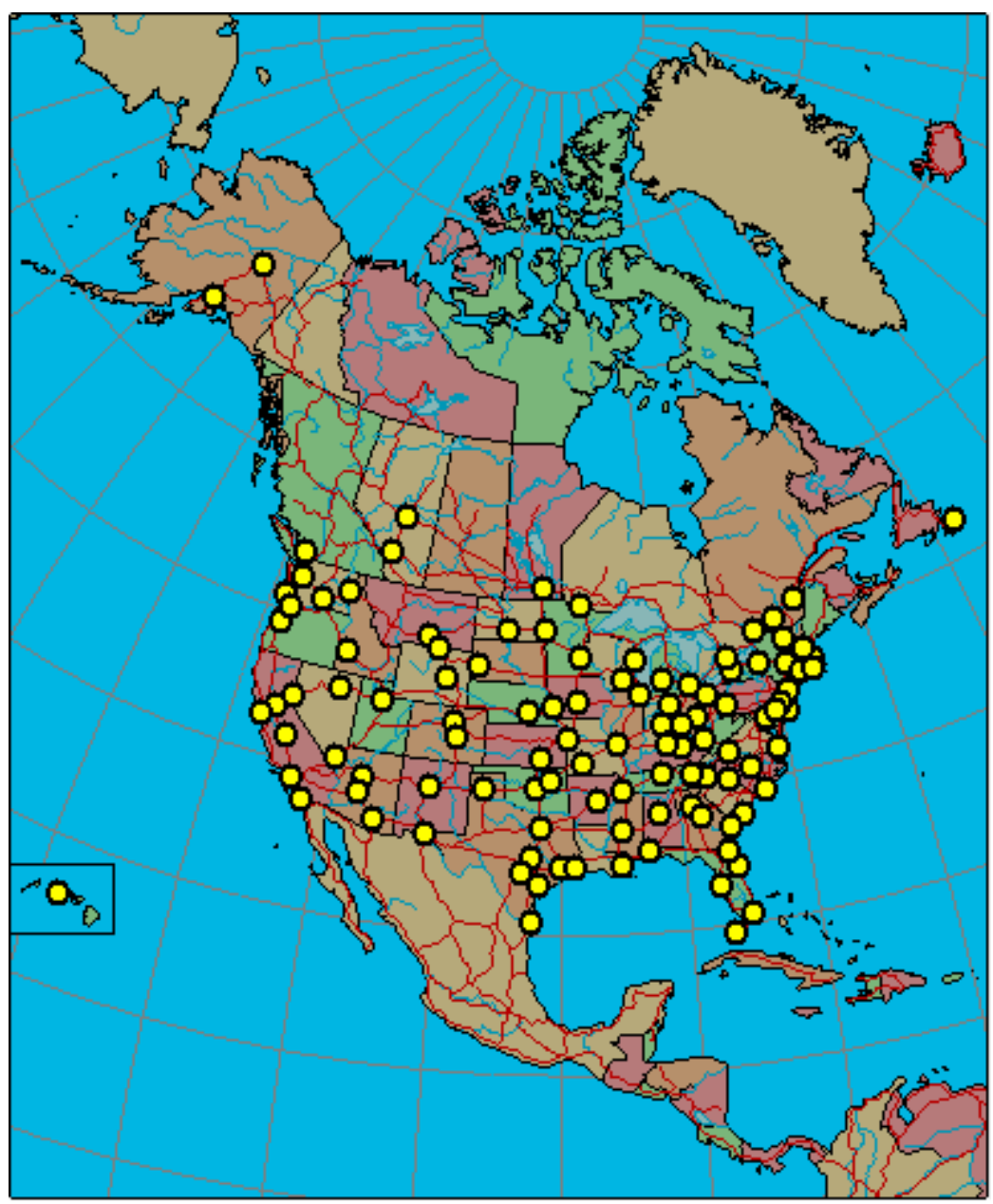

Figure 14. Climate locations for Phase 1 economic analysis

Key parameters of the study building were:

- 40 feet long by 26 wide by 19 high exterior dimensions, two stories, three bedrooms, two baths

- Finished floor area $2,080 \mathrm{ft}^{2}$, notional treated floor area $1,560 \mathrm{ft}^{2}$

- Oriented short side south with neighbors at 20 feet east and west

- Vented attic with cellulose insulation

- Exterior-foam wall assembly

- Slab-on-grade foundation

- Window U-values constrained for comfort, location by location

- Window area $15 \%$ of wall area (up to $40 \%$ concentration on south or north)

- Airtight, ducts inside

- All-electric. 
The TC also approved a number of other calculation protocol details (see Appendix A). Some discussion was required to clarify which parameters should be available for the optimizer to vary, which should (from a passive building characteristic point of view) be reset to different values than the B10 benchmark and then held fixed, and which should be left at benchmark values. Figure 15 shows the BEopt visualization of the study building.

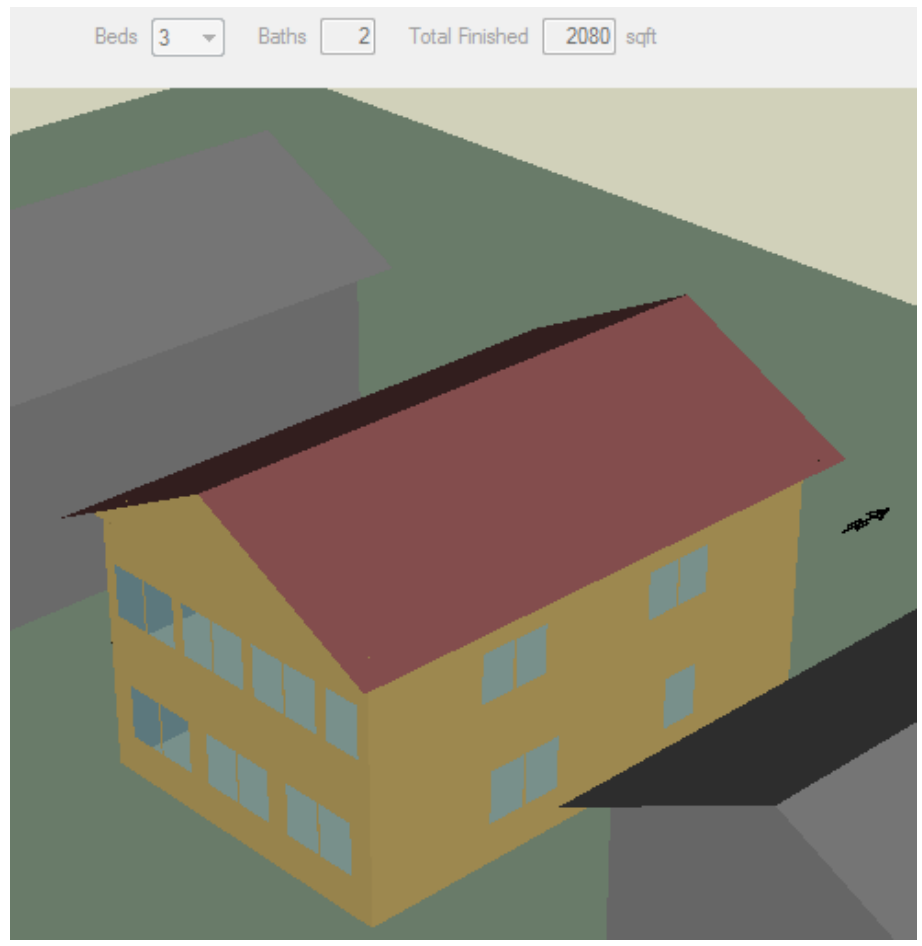

Figure 15. BEopt visualization of the study building

A report format was developed that consists of three charts and a data table for each location. Examples are shown below for the case of Chicago, Illinois (along with a screenshot of the BEopt output window in Figure 16). On each chart the optimal curve of annualized cost versus percentage energy savings (site) is plotted in green against the left axis. Indicator traces at the bottom blip upward at the PV and solar hot water start points.

Figure 17 also shows the incremental capital cost per gross square foot of floor area in red against the right axis. An alternative "conservation-only" version of the optimal curve is also plotted in blue, which has the renewables contributions edited out of the sequence (the cost and energy savings increments at the PV start and solar hot water start steps are subtracted from the succeeding points). ${ }^{2}$

Figure 18 illustrates annual heating and cooling demands per square foot of notional treated floor area. Figure 19 illustrates the heating and cooling peak loads or system capacities that BEopt determines according to the Air Conditioning Contractors of America Manual J calculation, again per square foot of treated floor area. The dark blue line shows the source energy per person in $\mathrm{MWh} /$ year.

\footnotetext{
${ }^{2}$ This is not a perfect adjustment-if another option changes at the same step as PV start or solar hot water start, its cost and energy savings increments are subtracted as well. This was not a common occurrence.
} 
Table 11 lists all the graphed data and Table 12 shows a subset of the option configuration for each optimal point. User-defined options are indicated by the suffix "gw."

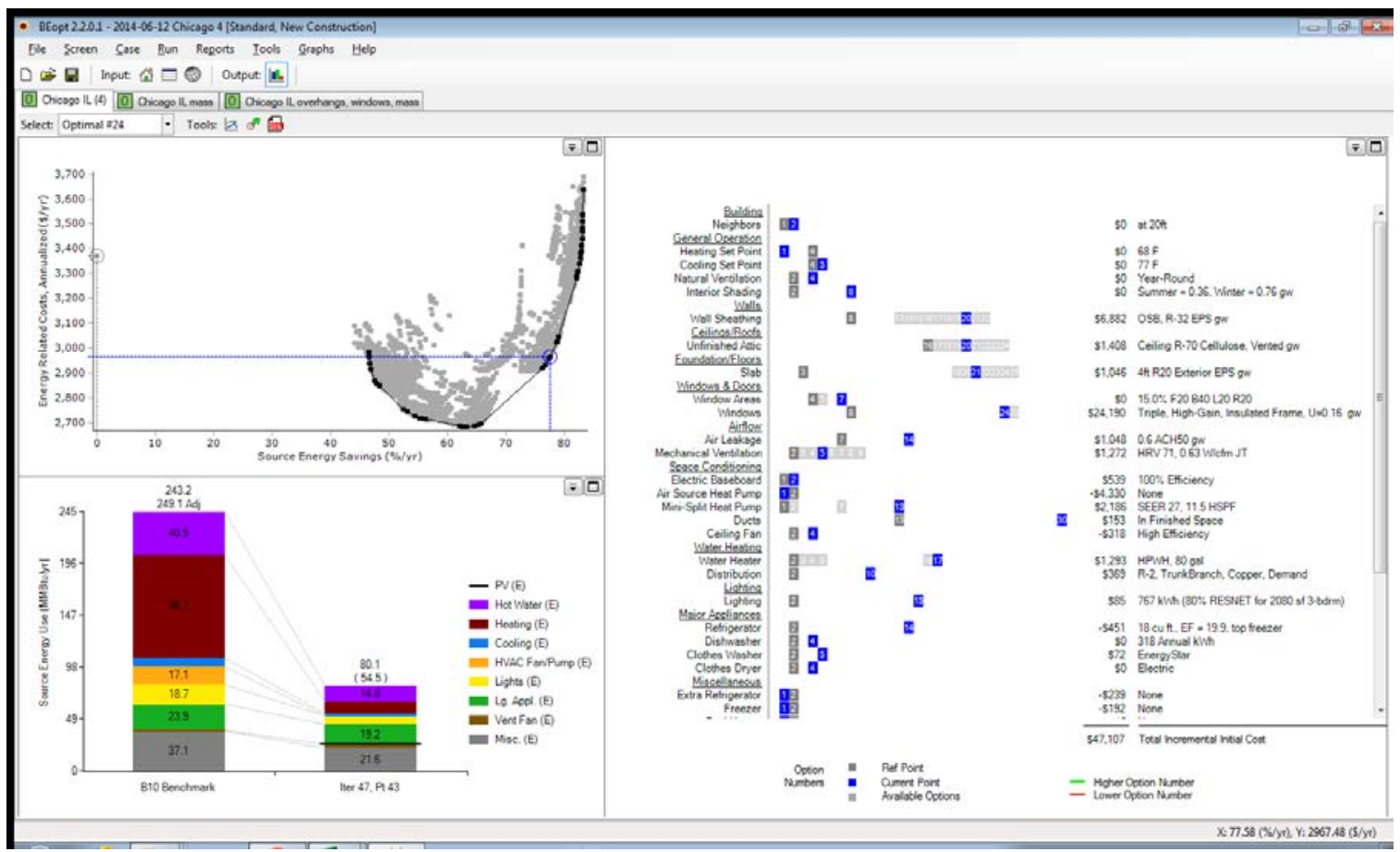

Figure 16. BEopt output screen, Chicago Illinois, at chosen cost-competitive point

Case: Chicago IL (4)

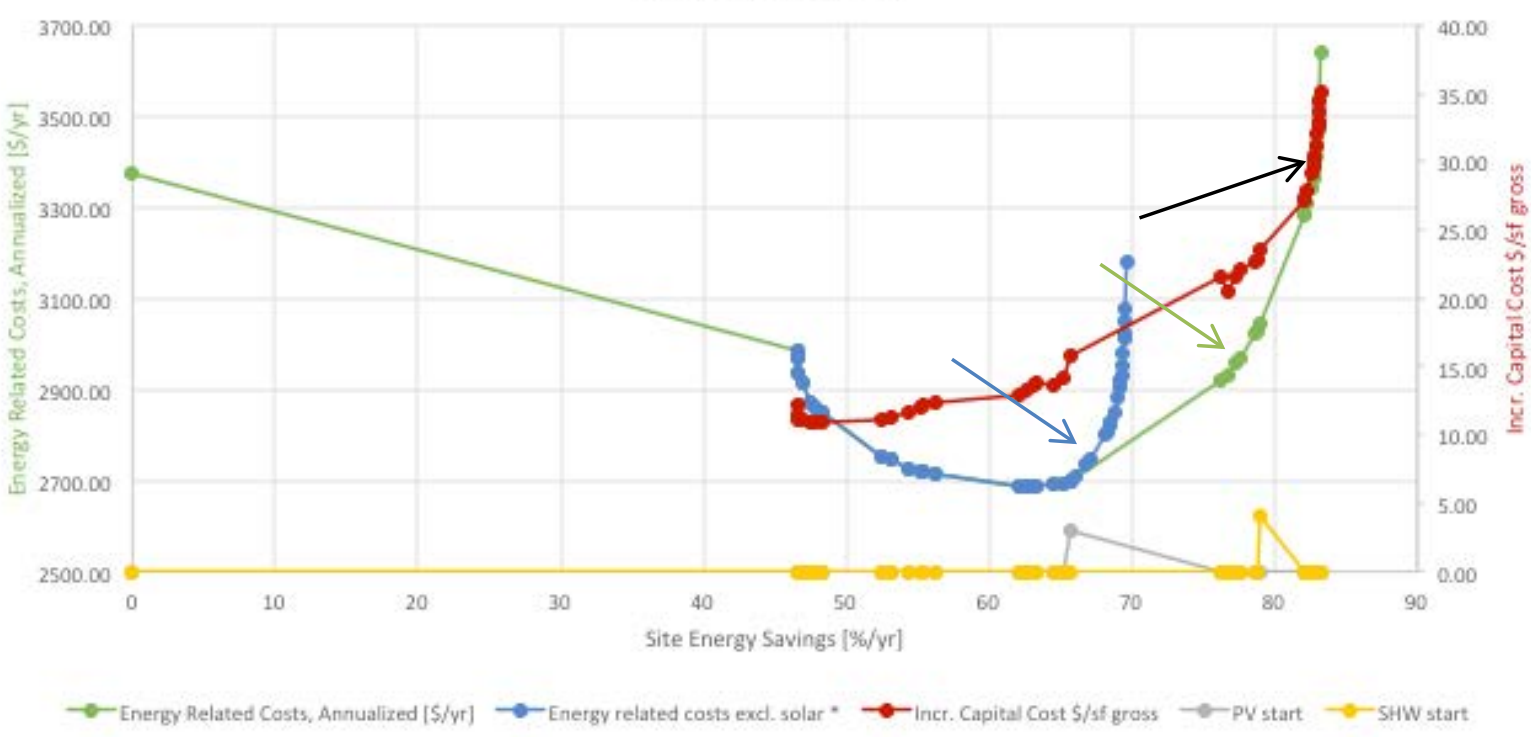

Figure 17. Economic analysis report example, Chicago Illinois, annualized costs and first-cost premium 
Case: Chicago IL (4)

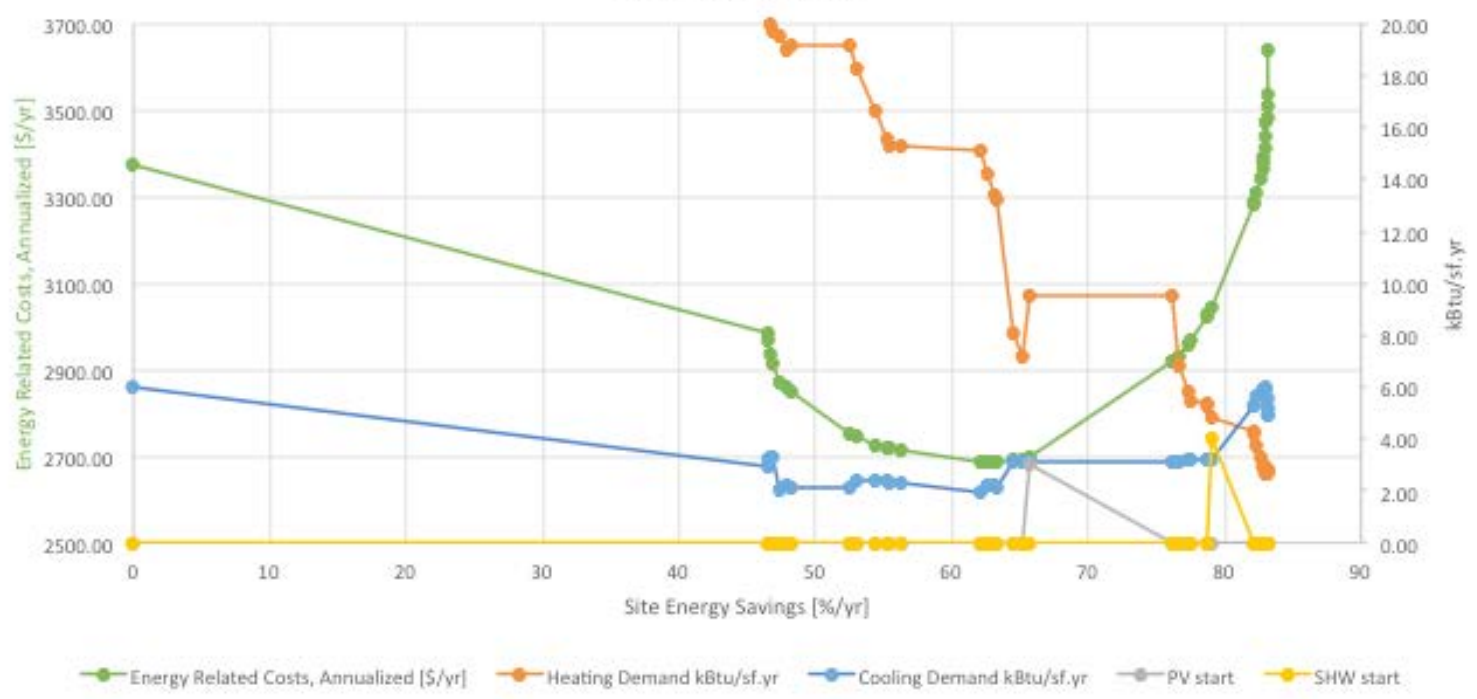

Figure 18. Economic analysis report example, Chicago Illinois, heating/cooling demand chart

A number for comparison here is the current certification limit of $4.75 \mathrm{kBtu} / \mathrm{ft}^{2} /$ year. Compared to PHPP calculations, the miscellaneous electricity load and lighting and internal heat gain increase incorporated here reduces modeled annual heating demand by about $1.5-2 \mathrm{kBtu} / \mathrm{ft}^{2} /$ year and increases cooling demand. That is, the same building would have modeled with higher annual heating demand under PHPP assumptions.

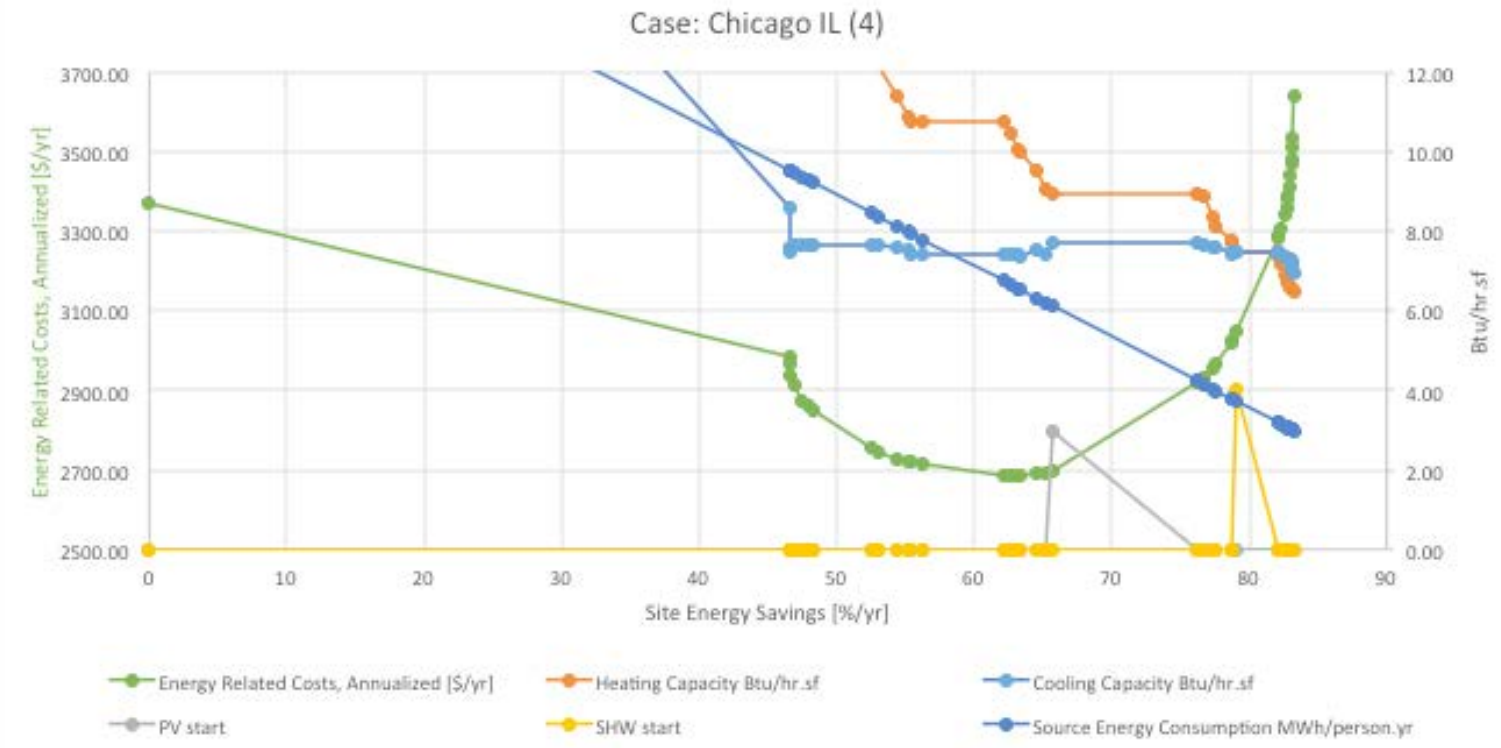

Figure 19. Economic analysis report example, Chicago Illinois, peak load chart (per Manual J)

Table 11 picks out some key points. Optimal point 14 was the minimum cost point. Optimal point 19 was the PV start point where BEopt determined it makes more sense to add PV instead of conserving more energy. 
Table 11. Economic Analysis Report, Example Table for Chicago, Illinois

\begin{tabular}{|c|c|c|c|c|c|c|c|c|c|c|c|c|c|}
\hline & 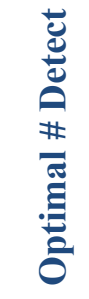 & $\stackrel{\overrightarrow{0}}{0}$ & 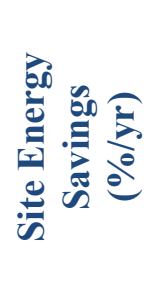 & 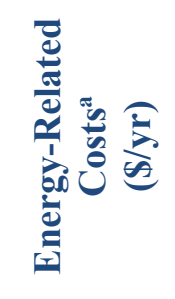 & 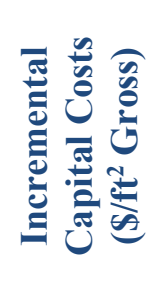 & 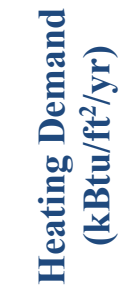 & 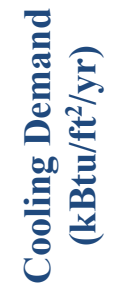 & 绨 & 竞 & 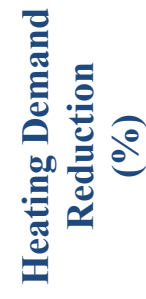 & 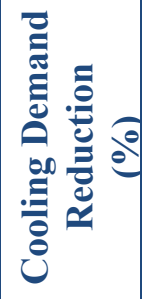 & 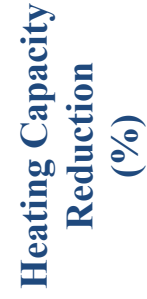 & 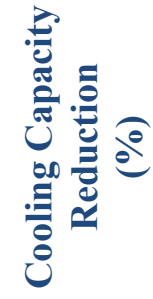 \\
\hline & & B10 Benchmark & 0 & $3,372.44$ & 0 & 49.17 & 6.01 & 42.51 & 26.28 & & & & \\
\hline 1059 & 0 & Start & 46.55 & $2,984.71$ & 11.13 & 20.10 & 2.94 & 13.42 & 8.58 & 59 & 51 & 68 & 67 \\
\hline 1060 & 1 & Iter 14 , Point 18 & 46.60 & $2,966.89$ & 12.21 & 20.07 & 3.21 & 12.60 & 7.49 & 59 & 46 & 70 & 72 \\
\hline 1061 & 2 & Iter 14 , Point 19 & 46.68 & $2,937.31$ & 11.48 & 19.98 & 3.27 & 12.60 & 7.57 & 59 & 46 & 70 & 71 \\
\hline 1072 & 13 & Iter 26 , Point 28 & 62.08 & $2,687.04$ & 12.93 & 15.12 & 1.93 & 10.74 & 7.44 & 69 & 68 & 75 & 72 \\
\hline 1073 & $14^{b}$ & Iter 27 , Point 28 & 62.60 & $2,684.90$ & 13.25 & 14.23 & 2.18 & 10.47 & 7.44 & 71 & 64 & 75 & 72 \\
\hline 1074 & 15 & Iter 28 , Point 30 & 63.21 & $2,685.06$ & 13.69 & 13.44 & 2.18 & 10.08 & 7.40 & 73 & 64 & 76 & 72 \\
\hline 1075 & 16 & Iter 29 , Point 27 & 63.34 & $2,685.19$ & 13.79 & 13.25 & 2.13 & 9.97 & 7.34 & 73 & 65 & 77 & 72 \\
\hline 1076 & 17 & Iter 39 , Point 31 & 64.56 & $2,690.07$ & 13.66 & 8.07 & 3.14 & 9.56 & 7.53 & 84 & 48 & 78 & 71 \\
\hline 1077 & 18 & Iter 41, Point 38 & 65.19 & $2,693.37$ & 14.21 & 7.21 & 3.14 & 9.06 & 7.42 & 85 & 48 & 79 & 72 \\
\hline 1078 & $19^{c}$ & Iter 53, Point 30 & 65.70 & $2,697.59$ & 15.82 & 9.52 & 3.14 & 8.96 & 7.69 & 81 & 48 & 79 & 71 \\
\hline 1079 & 20 & Iter 52, Point 30 & 76.23 & $2,920.46$ & 21.50 & 9.52 & 3.14 & 8.96 & 7.69 & 81 & 48 & 79 & 71 \\
\hline 1080 & 21 & Iter 47 , Point 42 & 76.67 & $2,932.85$ & 20.51 & 6.79 & 3.14 & 8.88 & 7.65 & 86 & 48 & 79 & 71 \\
\hline 1081 & 22 & Iter 35 , Point 33 & 77.34 & $2,957.68$ & 21.65 & 5.85 & 3.20 & 8.33 & 7.60 & 88 & 47 & 80 & 71 \\
\hline 1082 & 23 & Iter 47 , Point 43 & 77.59 & $2,967.48$ & 22.10 & 5.51 & 3.20 & 8.13 & 7.58 & 89 & 47 & 81 & 71 \\
\hline 1083 & 24 & Iter 52, Point 35 & 78.69 & $3,022.22$ & 22.70 & 5.40 & 3.20 & 7.77 & 7.49 & 89 & 47 & 82 & 71 \\
\hline 1084 & 25 & Iter 59, Point 35 & 78.76 & $3,027.53$ & 22.90 & 5.28 & 3.20 & 7.69 & 7.44 & 89 & 47 & 82 & 72 \\
\hline 1085 & $26^{\mathrm{d}}$ & Iter 59 , Point 45 & 79.03 & $3,045.99$ & 23.58 & 4.88 & 3.20 & 7.46 & 7.46 & 90 & 47 & 82 & 72 \\
\hline 1086 & 27 & Iter 61 , Point 14 & 82.09 & $3,283.28$ & 27.13 & 4.32 & 5.33 & 7.46 & 7.46 & 91 & 11 & 82 & 72 \\
\hline
\end{tabular}

${ }^{a}$ Annualized

${ }^{\mathrm{b}}$ Minimum cost

${ }^{c}$ PV start

d Solar hot water start 
Table 12. Option Configuration (subset) at the Optimal Points Listed in Table 11

\begin{tabular}{|c|c|c|c|c|c|}
\hline Wood Stud & Wall Sheathing & $\begin{array}{c}\text { Exterior } \\
\text { Finish }\end{array}$ & Unfinished Attic & $\begin{array}{l}\text { Radiant } \\
\text { Barrier }\end{array}$ & Slab \\
\hline R-13 Fiberglass Batt, Gr-1, $2 \times 4,16$. in. o.c. & $\mathrm{OSB}^{\mathrm{a}}{ }^{\mathrm{R}}-5 \mathrm{XPS}^{\mathrm{b}}$ & Vinyl, light & R-38 cellulose, vented & None & 2-ft R-10 perimeter, R-5 gap XPS \\
\hline R-13 Fiberglass Batt, Gr-1, $2 \times 4$, 16. in. o.c. & OSB, R-5 XPS & Vinyl, light & R-38 cellulose, vented & None & 2-ft R-10 perimeter, R-5 gap XPS \\
\hline R-13 Fiberglass Batt, Gr-1, $2 \times 4,16$. in. o.c. & OSB, R-8 EPS, ${ }^{\mathrm{c}} \mathrm{gw}$ & Vinyl, light & R-38 cellulose, vented & None & 2-ft R-10 perimeter, R-5 gap XPS \\
\hline R-13 Fiberglass Batt, Gr-1, $2 \times 4$, 16. in. o.c. & OSB, R-8 EPS, gw & Vinyl, light & R-38 cellulose, vented & None & 2-ft R-10 perimeter, R-5 gap XPS \\
\hline R-13 Fiberglass Batt, Gr-1, $2 \times 4,16$. in. o.c. & OSB, R-16 EPS, gw & Vinyl, light & R-44 cellulose, vented & None & 4-ft R-8 exterior EPS gw \\
\hline R-13 Fiberglass Batt, Gr-1, $2 \times 4,16$. in. o.c. & OSB, R-16 EPS, gw & Vinyl, light & R-44 cellulose, vented & None & 4-ft R-20 exterior EPS gw \\
\hline R-13 Fiberglass Batt, Gr-1, $2 \times 4,16$. in. o.c. & OSB, R-20 EPS, gw & Vinyl, light & R-44 cellulose, vented & None & 4-ft R-20 exterior EPS gw \\
\hline R-13 Fiberglass Batt, Gr-1, $2 \times 4,16$. in. o.c. & OSB, R-20 EPS, gw & Vinyl, light & R-49 cellulose, vented & None & 4-ft R-20 exterior EPS gw \\
\hline R-13 Fiberglass Batt, Gr-1, $2 \times 4,16$. in. o.c. & OSB, R-16 EPS, gw & Vinyl, light & R-44 cellulose, vented & None & 4-ft R-20 exterior EPS gw \\
\hline R-13 Fiberglass Batt, Gr-1, $2 \times 4$, 16. in. o.c. & OSB, R-20 EPS, gw & Vinyl, light & R-49 cellulose, vented & None & 4-ft R-20 exterior EPS gw \\
\hline R-13 Fiberglass Batt, Gr-1, $2 \times 4,16$. in. o.c. & OSB, R-32 EPS, gw & Vinyl, light & R-70 cellulose, vented, gw & None & 4-ft R-20 exterior EPS gw \\
\hline R-13 Fiberglass Batt, Gr-1, $2 \times 4$, 16. in. o.c. & OSB, R-32 EPS, gw & Vinyl, light & R-70 cellulose, vented, gw & None & 4-ft R-20 exterior EPS gw \\
\hline R-13 Fiberglass Batt, Gr-1, $2 \times 4,16$. in. o.c. & OSB, R-20 EPS, gw & Vinyl, light & $\mathrm{R}-70$ cellulose, vented, gw & None & 4-ft R-20 exterior EPS gw \\
\hline R-13 Fiberglass Batt, Gr-1, $2 \times 4,16$. in. o.c. & OSB, R-28 EPS, gw & Vinyl, light & R-70 cellulose, vented, gw & None & 4-ft R-20 exterior EPS gw \\
\hline R-13 Fiberglass Batt, Gr-1, $2 \times 4,16$. in. o.c. & OSB, R-32 EPS, gw & Vinyl, light & R-70 cellulose, vented, gw & None & 4-ft R-20 exterior EPS gw \\
\hline R-13 Fiberglass Batt, Gr-1, $2 \times 4,16$. in. o.c. & OSB, R-32 EPS, gw & Vinyl, light & R-70 cellulose, vented, gw & None & 4-ft R-20 exterior EPS gw \\
\hline R-13 Fiberglass Batt, Gr-1, $2 \times 4,16$. in. o.c. & OSB, R-32 EPS, gw & Vinyl, light & $\mathrm{R}-80$ cellulose, vented, gw & None & 4-ft R-20 exterior EPS gw \\
\hline R-13 Fiberglass Batt, Gr-1, $2 \times 4,16$. in. o.c. & OSB, R-40 EPS, gw & Vinyl, light & $\mathrm{R}-70$ cellulose, vented, gw & None & 4-ft R-20 exterior EPS gw \\
\hline R-13 Fiberglass Batt, Gr-1, $2 \times 4,16$. in. o.c. & OSB, R-40 EPS, gw & Vinyl, light & $\mathrm{R}-70$ cellulose, vented, gw & None & 4-ft R-20 exterior EPS gw \\
\hline
\end{tabular}

a Oriented strand board

${ }^{\mathrm{b}}$ Extruded polystyrene

${ }^{\mathrm{c}}$ Expanded polystyrene 
Nine cases were presented for TC preliminary review. Committee members raised concerns about the interaction between the space-conditioning criteria and the source energy limit. That is, under the PHI protocol the space-conditioning criteria were usually the limiting factors; the source energy target was relatively easy to meet. But with higher lighting and plug load defaults and potentially higher space-conditioning thresholds the source energy limit could become the limiting factor.

Additional measures will need to be taken if source energy becomes harder to meet. The designer would be free to choose passive or active approaches. Therefore, the calculation protocol was modified (and started over) to include "full-sized" options for the on-site renewables in BEopt that count against the source energy limit; i.e., solar hot water and PV. The PV array is limited to $2 \mathrm{~kW}$ - small enough that most of its output would be used live on site and therefore count as reducing source energy (under the TC's previous resolution). In earlier rounds only a small 200or 500-W system was used to "detect" the PV start point for comparison; in the first round the optimizer was given passive parameters only. In the final round the optimizer had all three parameter types - passive, efficient equipment, and renewables. That round gives a complete view of the economics and of how passive measures fare in different climates.

\subsection{Standard-Setting Heuristic}

The PV start point would be a defensible level at which to set the criteria. But a more aggressive point may be appropriate on the cost-optimal curve - one that is still cost-competitive but has lower annual dollar savings.

The team found two motivations for pushing past the PV start point:

The first could be called the "nonenergy benefits argument." The higher hanging measures reduce the peak loads, deliver high levels of thermal comfort, and provide many resilience benefits.

The rationale is that passive measures are better for the building owners and occupants than renewable generation alone. They increase the building's resilience to utility outages by minimizing heat losses and thus allow interior temperature "coasting" during outages. Therefore, passive building is a strategy for adapting to - not just for mitigating - climate change (and the changes are already occurring).

The tradeoff is that the harder the space-conditioning criteria are pushed the greater the nonenergy benefits but the lower the cost-competitiveness. The source energy limit is independent from that tradeoff and ensures that environmental challenges are met in either case (approximately a $60 \%$ chance of $2^{\circ} \mathrm{C}$ warming or less).

The peak loads could be considered a proxy for such nonenergy benefits. An optimization process in BEopt for peak load reductions on the X-axis could be envisioned. But that method could sacrifice site energy savings to peak load reduction. The TC members agreed that the energy savings should take priority. BEopt does that and therefore was used as-is; however, net energy savings is not the sole consideration. The TC as a whole decided to forgo some annual dollar savings if more peak load reductions could be realized.

The second rationale to push beyond the cost-optimal point could be called the "risk argument." Although the TC decided that the economic analysis should be the driving factor and pointedly 
chose to assess it in a conventional way with conventional assumptions about the future, the method has known blind spots and the assumptions might not be right:

- A 30-year time horizon could be too short. Most buildings, especially those with passive measures such as insulation, last much longer and will continue to deliver savings with little or no maintenance.

- Outage risk and other secondary risks are not considered and should be. Electricity grid outages have increased in scale and frequency since 1995 (Amin 2011).

- Inflation and fuel escalation rate statistics are inaccurate or will change in the future; fuel price spikes accelerate payback quickly.

- BEopt assumes net metering at retail electricity price. If only wholesale price is offered, PV will become less attractive. This is the case in Illinois. The utility currently only pays wholesale and that only up to zeroing out the account at the end of each year.

Any or all of those considerations are valid reasons to push beyond the conventional economic optimum for more conservation and passive measures. Pushing past the cost optimum is arguably a conservative approach given the uncertainty of the future developments and possible climate risks.

There is an opportunity for passive building design (or top level high-performance building design) to achieve a much greater total impact through wider adoption. The best results will be achieved in a "window of operation" between two limits. On the one hand, aggressive performance standards can be set to deliver the benefits of passive building construction; on the other hand, they should not be set so aggressively that they yield diminishing returns and long paybacks that discourage mainstream adoption. This project aimed to set standards that hit this sweet spot.

The TC agreed on the following heuristics for setting the criteria:

- Note the PV start point.

- Note and pass just over the "knee" of conservation-only cost curve to the point at which conservation heads into diminishing returns. If that zone straddles an upgrade from exhaust ventilation only to HRVs, prefer the point with the HRV (HRVs reduce peak loads and ensure that fresh air is distributed evenly).

Exception: if source energy is far over the limit at PV start, pick PV start (do not invest more in passive measures if challenged on source energy limit; rather, save some money for on-site renewables or novel measures).

Comparison to cost parity with the benchmark was considered but was problematic for a couple of reasons:

- The unintended consequences of changing to an all-electric building and state-by-state electricity prices. In places with expensive energy, everything was affordable in a sense; even measures that were deep into diminishing returns still showed cash flow. In places with cheap energy, distressingly little was affordable. In these analyses the energy prices vary regionally but the construction costs do not; they are probably somewhat correlated, 
which would tend to level the results. Keying in on the diminishing returns behavior appeared to be a more robust procedure that is less sensitive to energy price variations.

- Eliminating the statistical fractions of extra miscellaneous loads from the study house provides an approximate $\$ 400$ /year cash flow boost, which is arguably "fake." That is, the annualized costs for the benchmark are overinflated, which gives the appearance that one could buy a lot of upgrades and still be ahead some dollars per year. This was particularly dramatic in the case of Alaska - the mini-split heat pump had a low coefficient of performance and bought huge amounts of expensive electricity.

In the Chicago example, applying the above heuristic gravitated to optimal point 23 or 24 . This straddles an upgrade from the $71 \%$ efficient HRV to the $88 \%$.

In Figure 19, the blue arrow indicates where optimal point \#23 is on the blue curve; the green arrow indicates it on the green curve, as do the crosshairs in the upper left pane of Figure 18. The black arrow indicates about where a design for $4.75 \mathrm{kBtu} / \mathrm{ft}^{2} /$ year annual heating demand would fall per PHPP calculation. (A $10 \mathrm{~W} / \mathrm{m}^{2}$ peak load design by PHPP would be at or slightly above the last point at the top of the chart.)

Each location case was reviewed and a knee-of-the-curve point was picked. In many cases it was difficult to decide between two adjacent points where a large step occurred (such as an HRV upgrade, solar hot water start, or multiple upgrades in one step). In such cases both options were recorded.

Also, feedback was solicited from builders of high-performance homes. They were asked what they could practically best implement in their markets and which study configuration most closely resembled that practice. Input from six locations was received and incorporated and generally confirmed that the heuristic was reasonable.

For summary, illustration, and comparison, the zone-by-zone median values that were picked for the space-conditioning criteria according to the above heuristic are shown in Table 13. The corresponding values from picking the PV start points are shown in Table 14.

The TC does not think this type of tabular approach is granular enough for program use. Rather, the curve-fit formulas should be incorporated into the energy modeling software and the criteria set in a continuous way.

Table 15 shows the percentage reductions in the heating and cooling loads from the BA benchmark. Again these are median values over all the chosen cost-competitive points, zone by zone. The table illustrates that generally the improvements are quite consistent with the "firstgeneration" notion about how low to go, especially considering that the benchmark itself improved somewhat between 1980 and 2009.

A comparison of the first two columns in Table 16 suggests that much of the cooling demand savings can be attributed to moving the ducts inside. An average sense can also be gleaned of how much more aggressive the "knee-of-the-curve" heuristic was compared to mechanically picking the PV start points. A comparison of the last two columns in Table 13 suggests that the heuristic was overall more aggressive with peak loads and heating demand but less aggressive with cooling demand. 
Table 13. Zone Median Space-Conditioning Targets by Diminishing Returns Heuristic

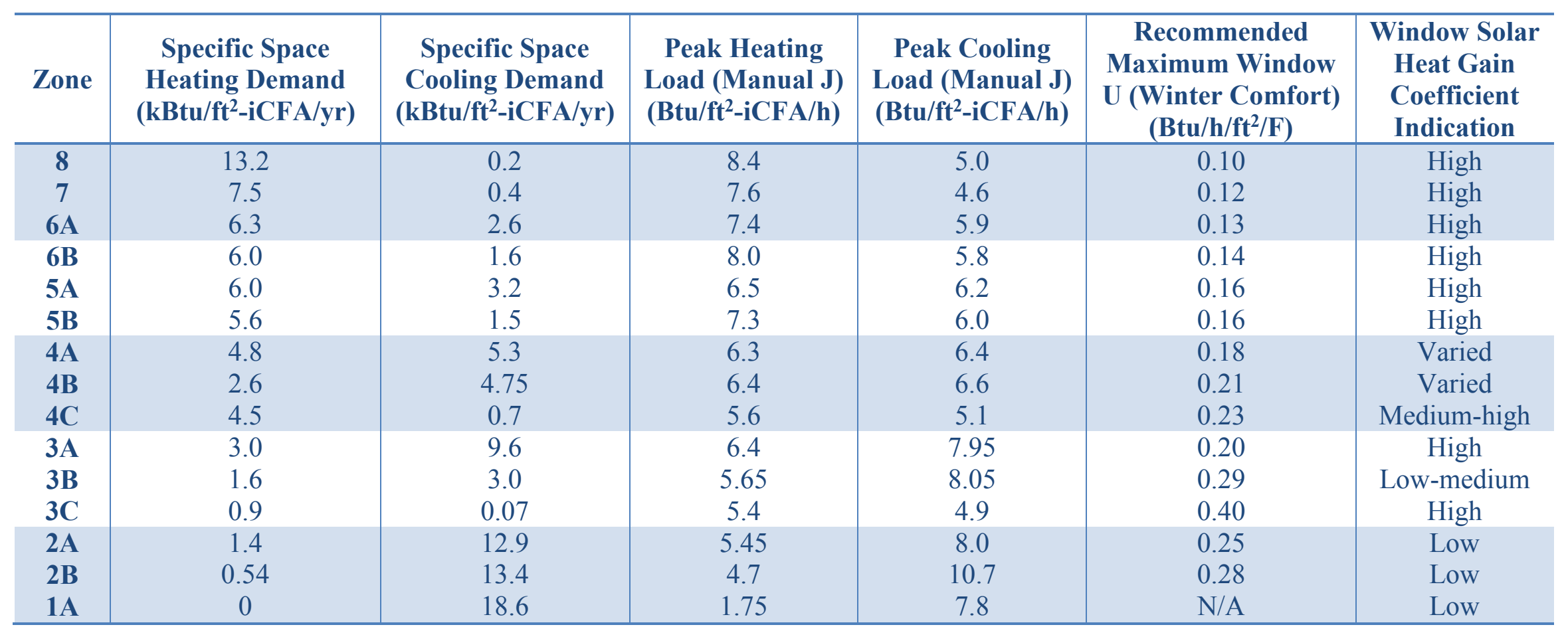


Table 14. Zone Median Space-Conditioning Targets by PV Start Rule

\begin{tabular}{|c|c|c|c|c|c|}
\hline Zone & $\begin{array}{c}\text { Specific Space- } \\
\text { Heating Demand } \\
\text { (kBtu/ft' }- \text { iCFA/yr) }\end{array}$ & $\begin{array}{c}\text { Specific Space- } \\
\text { Cooling Demand } \\
\left(\text { kBtu/ft' }{ }^{2} \text {-iCFA/yr) }\right.\end{array}$ & $\begin{array}{c}\text { Peak Heating } \\
\text { Load (Manual J) } \\
\left(\text { Btu/ft' }{ }^{2} \text {-iCFA/h) }\right.\end{array}$ & $\begin{array}{c}\text { Peak Cooling } \\
\text { Load (Manual J) } \\
\left(\text { Btu/ft' }{ }^{2} \text {-iCFA/h) }\right.\end{array}$ & $\begin{array}{c}\text { Recommended } \\
\text { Maximum Window U } \\
\text { (Winter Comfort) } \\
(\text { Btu/h/ft't } / \mathbf{F})\end{array}$ \\
\hline 8 & 13.2 & 0.2 & 8.4 & 5.0 & 0.10 \\
\hline 7 & 7.9 & 0.4 & 7.6 & 4.7 & 0.12 \\
\hline 6A & 7.6 & 2.0 & 7.5 & 5.9 & 0.13 \\
\hline 6B & 8.6 & 0.8 & 8.6 & 5.9 & 0.14 \\
\hline $5 A$ & 8.5 & 2.9 & 7.4 & 6.2 & 0.16 \\
\hline $5 B$ & 6.5 & 0.8 & 7.5 & 5.9 & 0.16 \\
\hline $4 \mathrm{~A}$ & 6.4 & 4.9 & 6.9 & 6.4 & 0.18 \\
\hline 4B & 4.6 & 2.9 & 6.7 & 6.4 & 0.21 \\
\hline $4 \mathrm{C}$ & 6.7 & 0.4 & 6.1 & 5.2 & 0.23 \\
\hline 3A & 4.2 & 8.9 & 7.1 & 8.3 & 0.20 \\
\hline 3B & 3.2 & 3.4 & 6.2 & 8.5 & 0.29 \\
\hline $3 \mathrm{C}$ & 3.1 & 0.15 & 6.05 & 4.9 & 0.40 \\
\hline 2A & 2.2 & 13.0 & 6.4 & 8.6 & 0.25 \\
\hline $2 B$ & 1.6 & 12.5 & 5.6 & 11.7 & 0.28 \\
\hline $1 \mathrm{~A}$ & 0 & 21.0 & 2.2 & 9.1 & N/A \\
\hline
\end{tabular}


Table 15. Zone-by-Zone All-Points Median Percentage Reductions From Benchmark (Pre-Recalculation Data)

\begin{tabular}{c|c|c|c|c}
\hline Zone & $\begin{array}{c}\text { Specific Space- } \\
\text { Heating Demand }\end{array}$ & $\begin{array}{c}\text { Specific Space- } \\
\text { Cooling Demand }\end{array}$ & $\begin{array}{c}\text { Peak Heating Load } \\
\text { (Manual J) }\end{array}$ & $\begin{array}{c}\text { Peak Cooling Load } \\
\text { (Manual J) }\end{array}$ \\
\hline $\mathbf{8}$ & 90 & 86 & 87 & 63 \\
$\mathbf{7}$ & 92 & 64 & 84 & 66 \\
6A & 91 & 47 & 84 & 70 \\
6B & 86 & 53 & 80 & 66 \\
5A & 88 & 44 & 81 & 71 \\
5B & 83 & 66 & 75 & 66 \\
4A & 85 & 42 & 78 & 73 \\
4B & 89 & 46 & 77 & 68 \\
4C & 83 & 55 & 74 & 62 \\
3A & 84 & 39 & 72 & 67 \\
3B & 82 & 55 & 68 & 63 \\
3C & 94 & 92 & 65 & 55 \\
2A & 80 & 46 & 69 & 69 \\
2B & 91 & 50 & 68 & 63 \\
1A & 96 & 42 & 69 & 69 \\
\hline
\end{tabular}

Table 16. All-Points Median Percentage Reductions From Benchmark

\begin{tabular}{c|c|c|c}
\hline & $\begin{array}{c}\text { Proposed Standards } \\
\text { (With Duct Loss in } \\
\text { Benchmark) }\end{array}$ & $\begin{array}{c}\text { Proposed Standards } \\
\text { (Excluding Duct Loss) }\end{array}$ & $\begin{array}{c}\text { PV Start Points } \\
\text { (Excluding Duct Loss) }\end{array}$ \\
\hline Heating Demand & $\sim 86$ & 77 & 68 \\
\hline Cooling Demand & $\sim 46$ & 29 & 35 \\
\hline Heating Capacity & 77 & 77 & 74 \\
Cooling Capacity & 69 & 69 & 67 \\
\hline
\end{tabular}

\subsection{Statistical Smoothing}

To simplify the results into rules that can be incorporated into energy modeling software and applied in energy policy, the team fitted the resulting space conditioning data to statistical models in terms of the following independent variables:

- HDD65 - the heating degree-days, base $65 \mathrm{~F}$.

- $C D D 65$ - the cooling degree-days, base $65 \mathrm{~F}$.

- $T_{D H}$ - the heating design dry bulb temperature $99.6 \%$, in degrees $\mathrm{F}$.

- $T_{D C}$ - the cooling design dry bulb temperature $0.4 \%$, in degrees $\mathrm{F}$.

- $D D H R$ - the dehumidification design humidity ratio $0.4 \%$, in grains $/ \mathrm{lb}$.

- $I G$ - the annual global solar radiation, in $\mathrm{kWh} / \mathrm{m} 2 . \mathrm{yr}$.

- $\quad P$ - the electricity price, marginal, state average (city-by-city for Canada), in $\$ / \mathrm{kWh}$ 
Electricity price data came from BEopt for U.S. locations and from utility websites for Canadian cities. Annual global solar radiation is from PHPP/WUFI-Passive static-calculation-formatted climate data files generated with Meteonorm. All the other data are from the ASHRAE Fundamentals 2013 data CD.

Statistical analysis was performed using JMP 11.2.0 (statistics software from SAS Institute, Inc.). A two-step analysis was done for each of the four responses (annual heating demand, annual cooling demand, peak heating load, and peak cooling load):

1. A screening fit was done to a model with main effects, two-way and three-way interaction terms, and quadratic terms.

2. The effects were rank ordered consistent with the Pareto principle and a simplified model was fitted using only the strongest terms. The goals for the simplified models are that (a) the remaining effects should be statistically significant and (b) the model should be understandable.

Appendix D shows an example of the screening fit for the peak cooling load. The simplified formulas "smooth" over "scatter" caused by the "lumpiness" of the option upgrades in BEopt and possible inconsistency in choosing the cost-competitive points. Of course there is residual lack-of-fit; the independent variables are not perfect predictors but the R-squared numbers are reasonable.

Figure 20 through Figure 23 and Equations 2 through 5 show the final fits for all four spaceconditioning criteria, that is, for the specific space heating and cooling demands SSHD and $S S C D$, and the peak heating and cooling loads per manual $\mathrm{J}$ calculation. The formulas shown are per square foot of iCFA. Data generated by the formulas are shown in Appendix C for all the study locations.

In the terminology of the statistics software, actual means the values from BEopt at the humanchosen cost-competitive points and predicted means the value calculated from the simplified statistical model.

In Figure 20, the slopes of the lines in the prediction profiler indicate that HDD is the strongest effect for annual heat demand. The formula for the annual heating demand target, Equation 2, can be explained as follows: Start with $4.92 \mathrm{kBtu} / \mathrm{ft}^{2} / \mathrm{yr}$. For every 1,341 HDDs at the project location, add $1 \mathrm{kBtu} / \mathrm{ft}^{2} / \mathrm{yr}$. But there are two take-backs. The greater the solar resource, the greater the reduction in annual heating demand. For every $482 \mathrm{kWh} / \mathrm{m}^{2} /$ year of global radiation, take back $1 \mathrm{kBtu} / \mathrm{ft}^{2} /$ year. Also, the higher the electricity price, the more upgrades you can afford, so for every $\$ 0.155 / \mathrm{kWh}$ you pay for electricity, take back $1 \mathrm{kBtu} / \mathrm{ft}^{2} /$ year. 


\section{Annual heating demand}

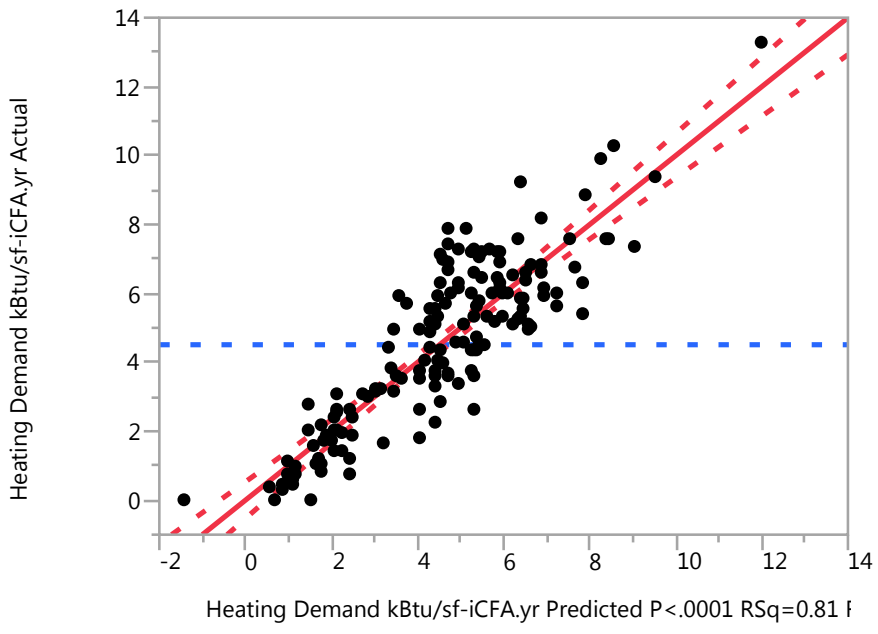

$$
\operatorname{SSHD}\left[\frac{\mathrm{kBtu}}{\mathrm{ft}^{2}-\mathrm{iCFA} \cdot \mathrm{yr}}\right]=4.92+\frac{H D D 65}{1341}-\frac{I G}{482}-\frac{P}{0.155}
$$

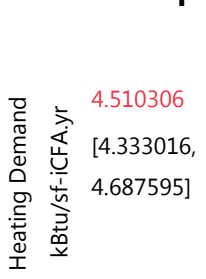

Prediction profiler
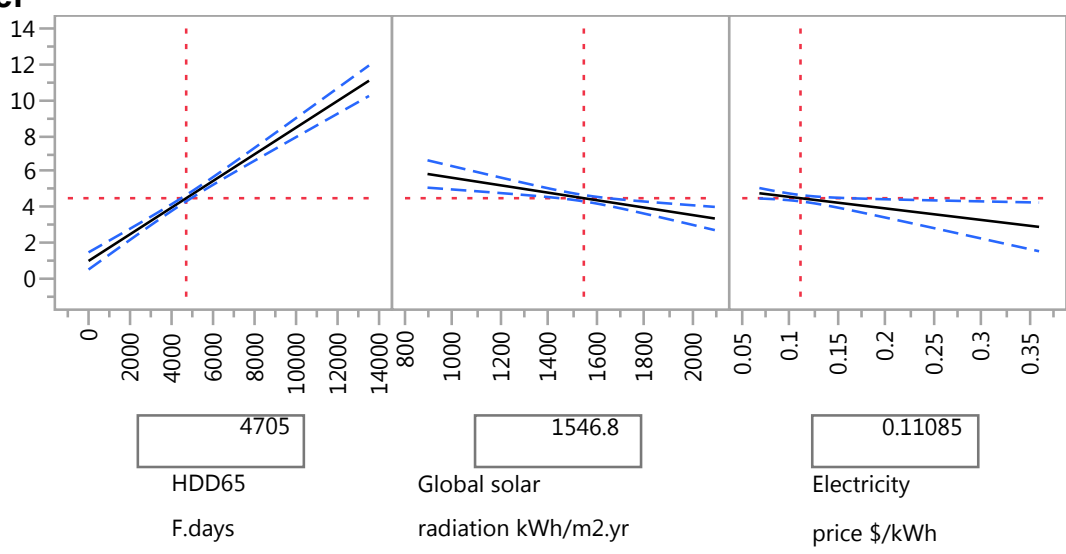

Figure 20. Formula for annual heating demand criterion 


\section{Annual cooling demand}

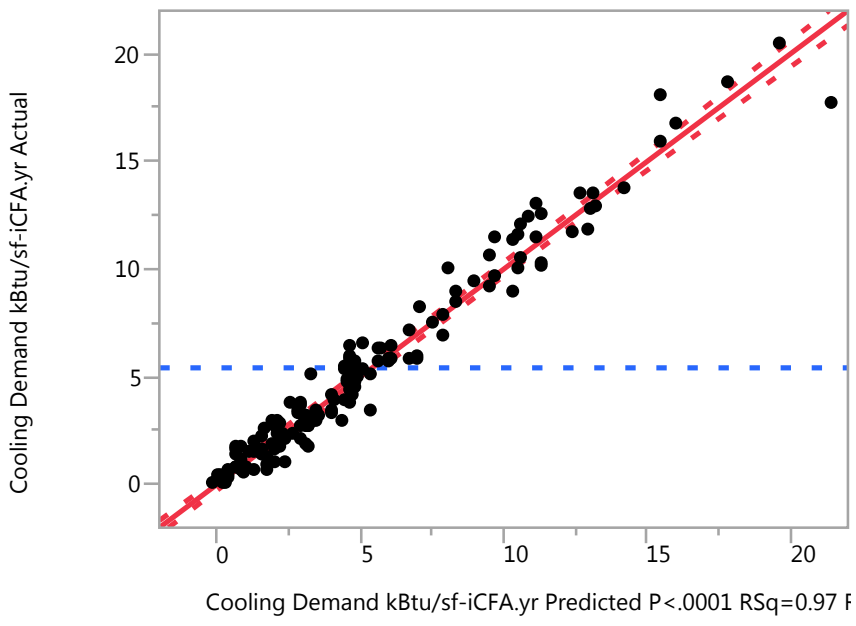

$$
\begin{gathered}
S S C D\left[\frac{\mathrm{kBtu}}{\mathrm{ft}^{2}-\mathrm{iCFA} \cdot \mathrm{yr}}\right]=-5.29+\frac{C D D 65}{292}+\frac{D D H R}{21.6} \\
+\frac{(C D D 65-1375.7) \cdot(D D H R-120.04)}{34812}
\end{gathered}
$$

\section{Prediction profiler ${ }^{3}$}

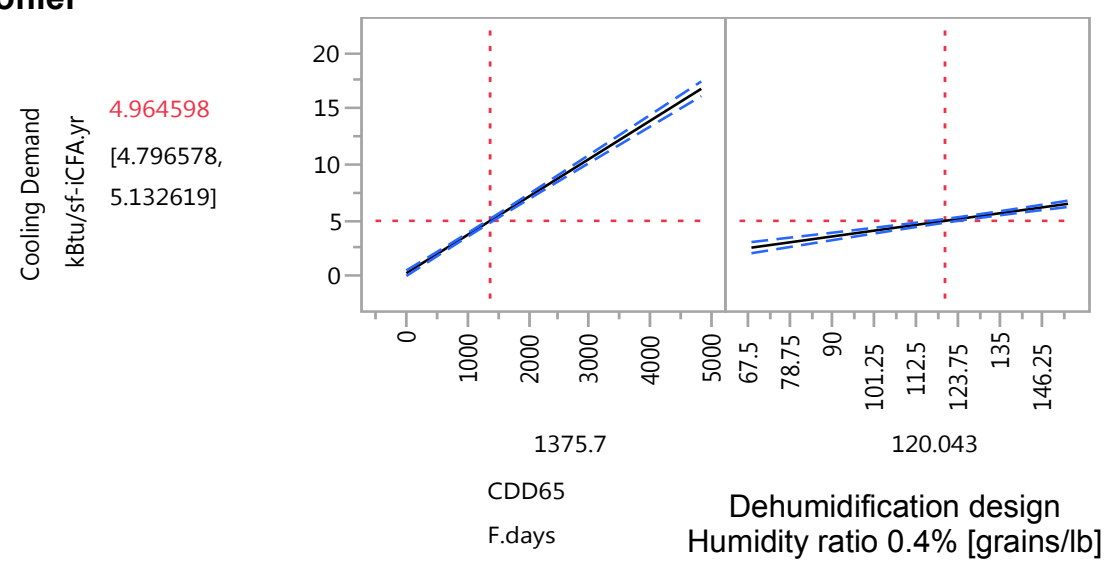

Figure 21. Formula for annual cooling demand criterion

Annual cooling demand, Equation 3 in Figure 21, was mostly about CDDs, but the humidity was also worth including as an additive term and as a synergistic interaction.

In the coldest climates the cooling demand formula could generate negative values; likewise, in the warmest climates the heating demand formula might generate a negative value. So the

\footnotetext{
${ }^{3}$ In JMP the profiler is an interactive chart. The numbers between the axes and their labels are the current factor settings and the value of the response at those settings (red text). The response values in square brackets are one standard error above and below.
} 
formulas should be implemented with an override to zero. That limit might still be too tight; therefore, the TC proposes to set the annual demand limits no lower than $1 \mathrm{kBtu} / \mathrm{ft}^{2} / \mathrm{yr}$.

\section{Heating capacity}

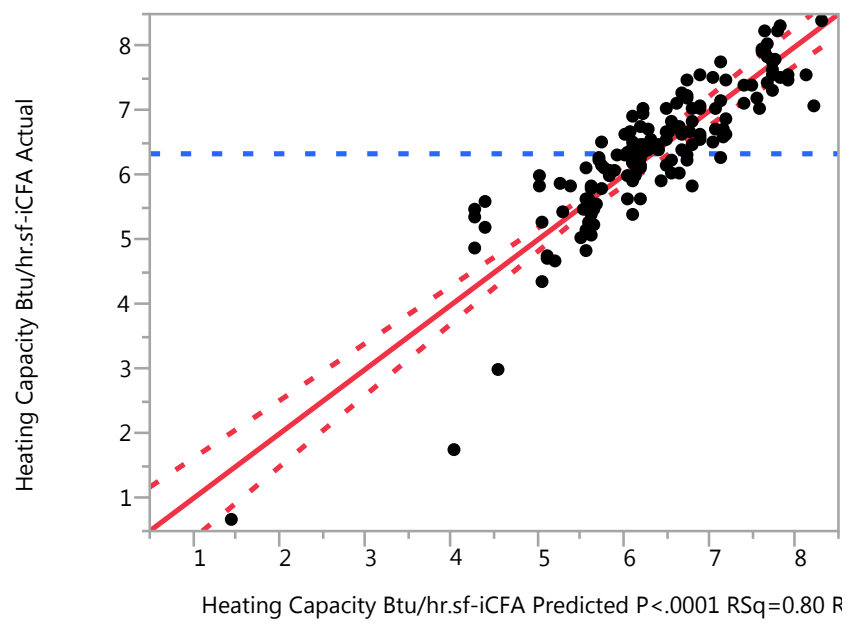

Peak heating load (Manual J) $\left[\frac{\mathrm{Btu}}{\mathrm{h} \cdot \mathrm{ft}^{2}-\mathrm{iCFA}}\right]=9.0-\frac{T_{D H}}{13.37}-\frac{H D D 65}{5232}-\frac{P}{0.125}$

\section{Prediction profiler}
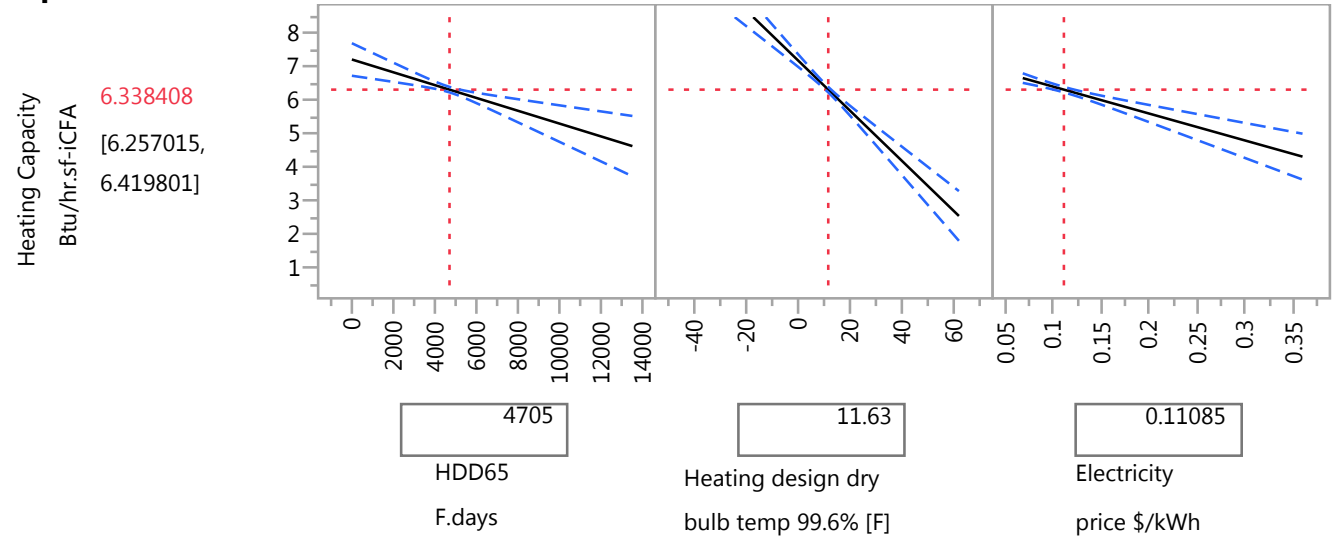

Figure 22. Formula for peak heating load criterion

The peak heating load, Equation 4 in Figure 22, is mainly controlled by the heating design temperature, which makes sense. But there is a take-back from HDDs: the limit is tightened the higher the degree-days because upgrades that pay in reducing annual heating demand also work for reducing peak heat load. Again there is a tightening with increasing electricity price. 


\section{Cooling capacity}

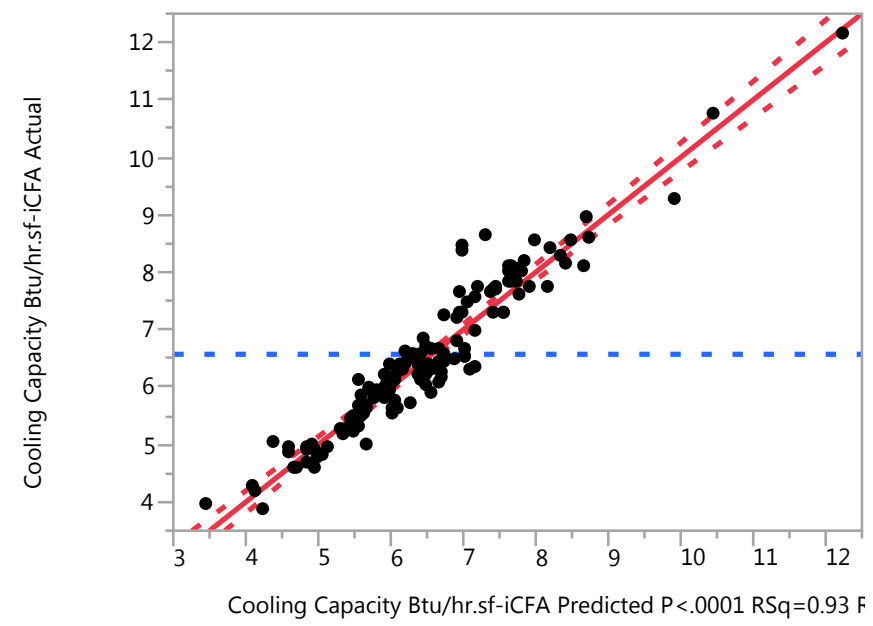

$$
\begin{gathered}
\text { Peak cooling load (Manual J) }\left[\frac{\mathrm{Btu}}{\mathrm{h} \cdot \mathrm{ft}^{2}-\mathrm{iCFA}}\right]=-8.12+\frac{T_{D C}}{7.32}+\frac{C D D 65}{2562}+\frac{D D H R}{86.3} \\
+\frac{(C D D 65-1376) \cdot\left(T_{D C}-92.4\right)}{27432}
\end{gathered}
$$

\section{Prediction profiler}
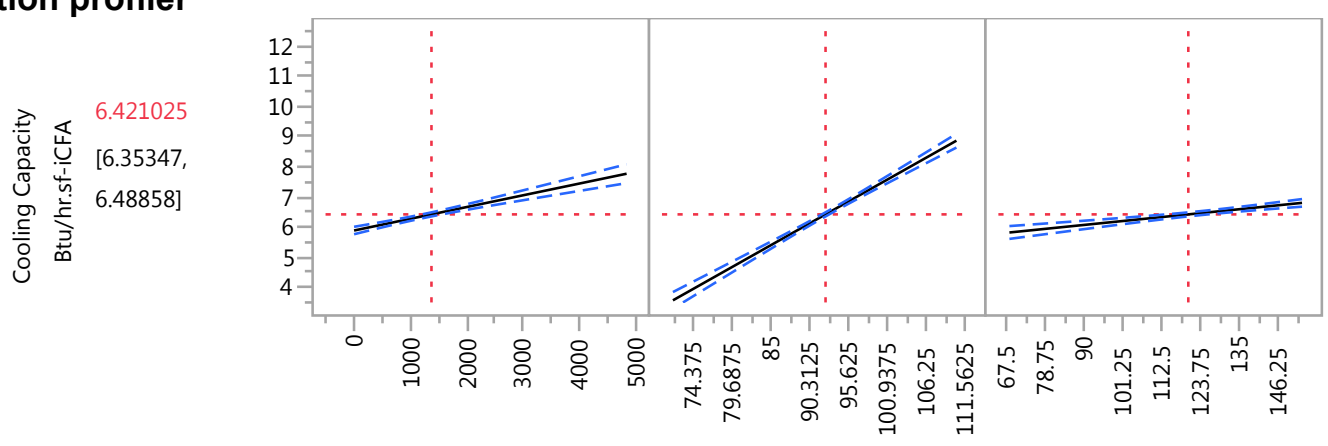

$$
\begin{array}{lrc}
\multicolumn{1}{c}{1375.7} & 92.387 & 120.043 \\
\text { CDD65 } & \text { Cooling design dry } & \begin{array}{c}
\text { Dehumidification design } \\
\text { F.days }
\end{array} \\
\text { bulb temp 0.4\% [F] } & \text { Humidity ratio 0.4\% [grains/lb] }
\end{array}
$$

Figure 23. Formula for peak cooling load criterion

Peak cooling load, Equation 5 in Figure 23, was the only metric that showed a strong interaction (the value of one factor changes the sensitivity to another). The strongest effect was cooling design temperature, but both an additional and a multiplicative allowance were needed with increasing CDDs. Some additional relief was needed the higher the dehumidification design humidity ratio. 
As mentioned earlier, outside the central European context $10 \mathrm{~W} / \mathrm{m}^{2}$ peak load does not always - and in North American climates rarely-represent a cost-competitive investment in passive measures.

In contrast, every point on the scatterplots created for this study represents a cost-competitive configuration as determined by BEopt analysis using U.S. construction and energy cost data; judgment is applied point by point. Thus, the annual demands and peak loads vary with climate and the heating targets vary with energy price. (The energy price effect was not statistically significant for cooling.)

\subsection{Thermal Comfort Check}

Given that the new criteria tolerate higher peak loads in some cases, the TC was concerned about how quickly the comfort benefits of passive measures might decline as the peak load exceeds the low-energy building or supply air heating sufficient level of $10 \mathrm{~W} / \mathrm{m}^{2}$. Phase 2 of the plan was to address this with thermal comfort verification checks. The idea was to first compare experimental data on temperature variation in a passive building versus a detuned version using a three-zone WUFI Passive dynamic model (warmest room, coldest room, rest of building) to see if that method could "pick up the signal" of increasing heat distribution difficulty with increased peak load. Then, for a limited subset of the study cases near the cost-optimal points, a similar three-zone model of the study building would be constructed in WUFI Passive and human comfort metrics would be checked; e.g., for two space-conditioning distribution configurations: point source and ducted.

Unfortunately those comfort checks have not yet been successfully completed and those data are still missing. The experimental data were not directly comparable between the passive and the lower performing buildings. Also, discrepancies between the models were observed between the results in the dynamic model in WUFI Passive and the single-zone BEopt model, even though (1) the geometry, assemblies, windows, and shading schedule all match; and (2) the internal gains, natural ventilation, attic climate, and ground temperatures are all driven by external hourly data files from EnergyPlus. More investigation into the causes of the differences in results in the models is necessary before the thermal comfort check can be performed with accuracy. Resolving this issue and studying how well peak loads can function as indicators for comfort are tasks for future work.

For the study at hand the lack of comfort checks is not a great concern because window U-value constraints were imposed to keep the window surface temperatures warmer than $60^{\circ} \mathrm{F}$ at the 12 hour mean minimum temperature (usually close to the $99.6 \%$ design temperature). Figure 24 shows example hourly output for Chicago using a WUFI Passive dynamic model. The window temperatures mostly exceed $60^{\circ} \mathrm{F}$. The only irregularity was observed during an early spring heat wave that occurred outside the time window when the cooling system was enabled per the BA House Simulation Protocols, so the inside became uncomfortably hot. In such a case that location might be rerun with an extended cooling season. 


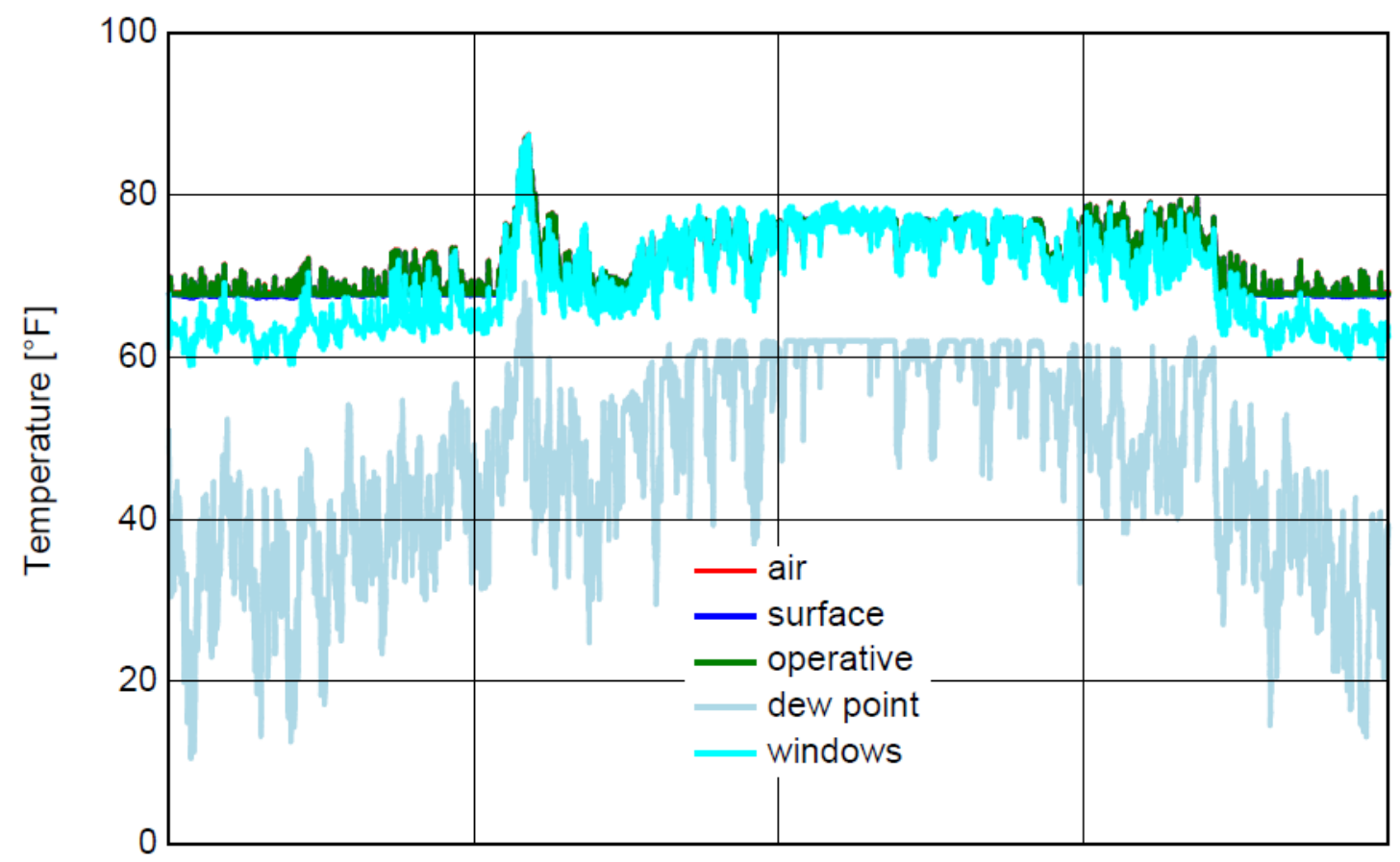

Figure 24. Interior conditions, hourly for the year, Chicago

\subsection{Peak Load Crossover}

Phase 3 of the test plan was concerned with peak load crossover calculations. At least three methods can be used to calculate peak loads:

- WUFI Passive (static mode such as PHPP)

- BEopt/Manual J (also a static calculation)

- WUFI Passive dynamic mode (reports the peak hour of the entire simulation).

BEopt outputs autosized heating capacity numbers per Manual J. Unlike WUFI Passive, Manual $\mathrm{J}$ gives no credit for the moderating effect of a long-time-constant building or the previous day's solar gains.

Best practice would be to run a dynamic model, look at the duration curve, and pick the $0.4 \%$ or $1 \%$ level. The TC suggests the two following compliance paths. Either:

Calculate peak loads per Manual J and use the Manual J-based targets as presented earlier

Or

Calculate with the static method according to Manual $\mathrm{J}$ and multiply the target value from the formulas by 0.6 for heating and 0.7 for cooling to convert to WUFI Passive/PHPP static mode calculation values. (These conversion factors are based on limited crossover calculations in zone 4A.) 


\section{Conclusions}

The aim of the study was to validate that performance-based climate-specific passive building standards are good tools to guide designs for cost-competiveness, best performance, and best thermal comfort before renewable production becomes the more economic choice on the path to zero energy buildings.

Two objectives were defined:

- Generate heating, cooling, and peak load criteria that would indicate sweet spots by climate.

- Develop simplified formulas to easily calculate criteria based on local climate data for inclusion in a design/modeling and verification tool.

The characteristics and energy reduction goals of two high-performance building programs were reviewed and synthesized: (1) the peak load criterion and the limit on annual source energy demand of the Passive House standard and (2) the approach of ZERH and BEopt of cost optimizing conservation versus generation measures.

BEopt was used to generate new climate-specific passive building standards for a study building in more than 100 climates. Assumptions were made according to best passive building practices - such as assumptions about airtightness levels and comfort requirements. The optimizer was appropriately constrained. Cost-optimal sets of measures were identified for each climate location. Annual heating and cooling demands and a peak heating and cooling load were identified as indexes at energy-saving levels that slightly exceeded the optimum calculated in BEopt.

By going beyond strict cost-optimality, the new standards "hedge against risk" or account for the fact that BEopt life cycle calculation cannot account for the environmental and attendant economic challenges in the future. Resilience and energy independence and their benefits are not valued in the model. Attempting to accurately quantify such values was beyond the scope of this study and the decision was made to set standards conservatively.

The proposed new standard therefore retains all defining characteristics of a passive building as defined by the first generation of pioneers - most notably it retains very low peak loads. The standard incents the optimization of conservation and generation according to ZERH and BEopt but includes a criteria hierarchy that promotes passive measures and low-grade energy resources before efficient equipment and renewable energy production are employed.

A set of simplified formulas was created to generate criteria based on local climate data. An agreement with the Fraunhofer Institute for Building Physics was reached to integrate the formula into the WUFI Passive design and verification tool. Fraunhofer also agreed to make a free limited version of WUFI Passive available to anyone who wishes to design and verify to the new climate-specific passive building standards.

A uniform source energy limit is deemed appropriate - everyone contributes to achieving the necessary carbon reductions for the planet. But the space-conditioning criteria are to benefit the building owners and occupants and are recalibrated for economic feasibility, which should 
encourage more passive building or top-level high-performance projects. Under the both-and system (limits on peak loads and annual demands as opposed to peak loads or annual demands), more projects will likely be challenged on peak loads and source energy instead of annual heating demand. This system will favor higher occupancy and more materials-efficient forms of housing.

This new system cannot guarantee cost-optimality or cost-competitiveness for any particular real project. However, this system will get significantly closer to these goals than would applying the European one-metric-fits-all climates approach; the new system is more nuanced and should keep project teams from pushing designs far into diminishing returns or leaving too many feasible energy savings on the table.

This study and the resulting new standard may be useful to policymakers. Energy consumption and the consequences of related carbon emissions are becoming public safety issues and so energy consumption may be regulated in the future. The shift to performance-based absolute energy metrics and energy use indices is necessary for building codes to require specific energy use in buildings and to then verify compliance. Such indexes must be validated by climate to incent cost optimal and appropriate design decisions. As outlined in Section 1.3, applying nonvalidated energy metrics can result in significant design mistakes and diminishing returns. The newly proposed climate-specific passive-building standard is validated in theory and calibrated appropriately to meet global energy and carbon reduction goals.

\subsection{Recommendations and Future Work}

The standard described here keys on low peak load, which serves as a proxy for two kinds of benefits - comfort with almost no mechanical assistance in normal operation and resilience to outages. Looking further to the future, metrics might be developed that measure those benefits more directly and set criteria for peak loads only instead of for annual and peak loads combined. This would simplify the criteria significantly.

Many experts agree on the overarching goal of zero energy and zero carbon buildings or even positive energy buildings by 2030. This study supports the idea of developing an additional certification (as an add-on) for achieving source zero energy performance by adding a renewable energy system after all other criteria have been met.

The top priorities for future work at this point are:

- Calculate peak load crossover. More data points need to be collected to compare the methods noted in Section 2.6 across a range of climates. The details about arriving at the moderated design temperatures that are used in the current calculation protocols for climate data need further analysis.

- Verify thermal comfort and check the temperature differential between zones. As noted in Section 2.5, a better way of calculating this benefit or lack thereof needs to be devised. In fact, two ways are probably needed - one for normal operation under consideration of the specific space-conditioning and air-distribution system and another for a utility outage scenario. Also, this study looked at constraining window U-value for winter comfort only. 
- Establish a ground contact calculation protocol (very different between EnergyPlus dynamic and PHPP/WUFI Passive). For an uninsulated slab, the PHPP/WUFI Passive calculation would typically reduce the HDDs applied to the bottom of the building by at most half. Because the only other insulation on the uninsulated slab is the R-1 air film, this method effectively assumes little more than a doubling of the floor R-value to about 2. However, EnergyPlus attributes much more effective resistance to the soil. A static 2-d THERM model of a 20 -foot wide building supported the idea that $1.5-\mathrm{W} / \mathrm{mK}$ soil can effectively amount to about R-17. The initial WUFI Passive static-mode crossover model of the study building in Chicago matched BEopt for annual heating demand with R-17 added under the floor but had much higher annual heating demand without it. The EnergyPlus method seems to predict much less heat loss to the ground than International Organization for Standardization 13370-based static calculations. If so and if EnergyPlus is right, designers who use PHPP/WUFI Passive design tools are overinsulating their floors. This discrepancy needs to be confirmed and corrected.

- Establish climate-dependent normalized PV utilization curves. One per climate zone will suffice.

- Conduct studies on possibly relaxing the airtightness criteria by climate. Again the airtightness requirement is driven mainly by moisture risk (energy savings are also important). Thus the danger threshold from a building science perspective would be climate dependent. Consider revisiting the blower-door test protocol. Perhaps the test should be conducted in two ways: (1) for energy modeling purposes, being realistic about leakage in normal operation; and (2) for durability, focusing on leakage through the assemblies. Less-threatening elements such as door thresholds and vent dampers would be taped off.

In summary, the proposed climate-specific passive-building standard has the same high-level organization as before. Changes are proposed for all three criteria.

The airtightness requirement was reconsidered on the basis of avoiding moisture and mold risk; dynamic hygrothermal simulations were used that will be published elsewhere. The proposed change is from a limit of $0.6 \mathrm{ACH} 50$ to $0.05 \mathrm{CFM} 50$ or $0.08 \mathrm{CFM} 75 / \mathrm{ft}^{2}$ of gross envelope area. This allows the airtightness requirement to scale appropriately based on building size. Before, a larger building that met the $0.6 \mathrm{ACH} 50$ requirement could be up to seven times leakier in terms of air leakage per unit area through the walls than a small single-family home that tested the same by volume air change rate. The moisture risk correlates with the leakage rate per unit area of surface rather than the volume rate. This change of scaling aligns with commercial building code and U.S. Army Corps of Engineers practice.

The source energy limit was reconsidered on the basis of the global $\mathrm{CO}_{2}$ emission budget. The following changes are proposed to make the scoring more equitable and the calculation more accurate:

- Change to a per-person limit rather than a limit per square foot of floor area - at least for residential projects. This follows the fair share principle. 
- Use the source energy factor for grid electricity of 3.16, which is in line with the U.S. national average according to the National Renewable Energy Laboratory's data and consistent with the value used in the IECC.

- Increase the lighting and miscellaneous plug load defaults to $80 \%$ of the RESNET defaults to better reflect U.S. usage and make the internal heat gain calculations consistent with those assumptions.

- To absorb the shock of the large increase in lighting and plug load defaults, temporarily relieve the source energy limit to $6,200 \mathrm{kWh} /$ person/year and tighten it to 4,200 again within a few years.

- Apply the limit to the source energy calculated net of the estimated fraction of on-site PV or other renewable electricity generation that is used on site as it is produced. This puts PV on a similar footing with how solar hot water is currently treated. (For the study building, most of the output of a 2-kW PV array would count depending on the climate.)

The space-conditioning criteria were reconsidered on the basis of economic feasibility. The proposed changes would:

- Shift to mandatory climate-specific thresholds for specific annual heating and cooling demands and peak heating and cooling loads, which are set at a cost-optimal sweet spot that slightly exceeds BEopt's cost optimum for a project's actual climate for increased resilience benefits. This ensures that efficiency measures will have reasonable payback relative to operational energy savings. The peak load thresholds could be adjusted to ensure hourly comfort or ensure the ability of the home to thermally coast through power outages.

- Establish the iCFA as an inclusive simplified interior-dimension floor area.

- The proposed standard presents three optimizing steps to zero source energy. The designer's attention is directed first to reducing heating and cooling energy use by passive means (including some mechanical devices). Furthermore, the designer is guided in employing such passive means in a cost-competitive manner by: (1) meeting the pass/fail energy metrics set by climate as presented in this report; (2) reducing total energy demand by using efficient equipment (and some renewables) and is guided in doing so by meeting the source energy criterion, which ensures that the fair-share global carbon limit is met; and (3) achieve zero source energy with more renewable energ generation, which can be reached at construction or postponed until 2030. 


\section{References}

Amin, S.M. (2011). “U.S. Grid Gets Less Reliable.” IEEE Spectrum, p. 80, January 2011.

ASE (2013). The History of Energy Efficiency. Commission on National Energy Efficiency Policy of the Alliance to Save Energy, January

2013. https://www.ase.org/sites/ase.org/files/resources/Media\%20browser/ee commission_histor y report 2-1-13.pdf.

ASHRAE (2013). ASHRAE Handbook, Fundamentals. Atlanta, GA: American Society of Heating, Refrigerating and Air-Conditioning Engineers, Inc.

Biello, D. (2010). "Where did the Carter White House's Solar Panels Go?," Scientific American, August 6, 2010. http://www.scientificamerican.com/article/carter-white-house-solar-panel-array/

Chiras, D. (2005). "Sun-Wise Design: Avoiding Passive Solar Design Blunders," Home Power 105, pp. 38-44, February-March 2005.

Christensen, C.; Horowitz, S; Givler, T.; Courtney, A; Barker, G. (2005). "BEopt: Software for Identifying Optimal Building Designs on the Path to Zero Net Energy." Conference Paper Golden, CO: National Renewable Energy Laboratory, NREL/CP-550-37733. ISES 2005 Solar World Congress, Orlando, FL, August 2005.

Christensen, C.; Anderson, R.; Horowitz, S.; Courtney, A.; Spencer, J. (2006). "BEopt Software for Building Energy Optimization: Features and Capabilities.” NREL/TP-550-39929, National Renewable Energy Laboratory, August 2006.

Deru, M.; Torcellini, P. (2007). Source Energy and Emission Factors for Energy Use in Buildings. Golden, CO: National Renewable Energy Laboratory, NREL/TP-550-38617.

Dockx, J. (2013). "Brussels Action Plan for Net Zero Energy Buildings” Conference Presentation, Passive House Northwest, Seattle WA, March 2013.

Dumont, R.S.; Besant, R.W.; Jones, G; Kyle, R. (1978) "Passive Solar Heating-Results from Two Saskatchewan Residences." Proceedings of the $4^{\text {th }}$ Annual Conference of the Solar Energy Society of Canada, Inc., London Ontario, August 20-24, 1978. http://www.phius.org/documents/PassiveSolarHeatingResultsRobDumont1978.pdf.

Ecotope (2010). 16 ${ }^{\text {th }} \&$ Nebraska Passive House, first year billing analysis (unpublished).

EIA (2008). Energy Efficiency Trends in Residential and Commercial Buildings. Washington, DC: U.S. Department of Energy. Accessed May 15, 2015: http://apps1.eere.energy.gov/buildings/publications/pdfs/corporate/bt stateindustry.pdf.

EIA (2013). Frequently Asked Questions. Washington, DC: U.S. Energy Information Administration. Accessed May 15, 2015: http://www.eia.gov/tools/faqs/faq.cfm?id=86\&t=1.

EU (2010). "Directive 2010/31/EU of the European Parliament and of the Council of 19 May 2010 on the Energy Performance of Buildings (Recast)." Official Journal of the European 
Union, L 153/13. Accessed May 15, 2015: http://eur-lex.europa.eu/legalcontent/EN/TXT/PDF/?uri=CELEX:32010L0031\&from=EN.

Grove-Smith, J; Pfluger, R. (2013). “Passive House: The All-Climate Optimum!”, Conference presentation, GreenBuild, Philadelphia, PA, Nov 20, 2013.

http://www.usgbc.org/education/sessions/passive-house-all-climate-optimum-4941657

Holladay, M. (2010). "The History of Superinsulated Houses in North America." Conference Presentation, $14^{\text {th }}$ Annual Westford Symposium on Building Science, Westford, MA, August, 2013. http://www.greenbuildingadvisor.com/blogs/dept/musings/history-superinsulated-housesnorth-america

ICC (2012). International Energy Conservation Code. Country Club Hills, IL: International Code Council.

IPCC (2013). Climate Change 2013: The Physical Science Basis, Summary for Policymakers, p. 27. Geneva, Switzerland: Intergovernmental Panel on Climate Change. Accessed May 15, 2015: http://www.ipcc.ch/pdf/assessment-report/ar5/wg1/WG1AR5 SPM_FINAL.pdf.

IPCC (2014). Climate Change 2014 Synthesis Report, Summary for Policymakers, p. 17. Geneva, Switzerland: Intergovernmental Panel on Climate Change. Accessed May 15, 2015: https:/www.ipcc.ch/pdf/assessment-report/ar5/syr/AR5 SYR_FINAL_SPM.pdf

Jacobson, R. (2013). "Passive House Certification in Scandinavia." $8^{\text {th }}$ Annual North American Passive House Conference, Pittsburgh, PA.

Kruger, B. (2012). A Proposed Methodology for Determining Climate-Dependent Passive House Standards for the United States. Master's Thesis, University of Colorado, 2012.

Laustsen, J. (2008). Energy Efficiency Requirements in Building Codes, Energy Efficiency Policies for New Buildings. Washington, DC: International Energy Agency. Accessed May 15, 2015: https://www.iea.org/publications/freepublications/publication/Building_Codes.pdf.

Nisson, N.; Dutt, G. (1985). The Superinsulated Home Book. John Wiley \& Sons.

PHI (2014). “The Passive House_-Definition.” Darmstadt, Germany: Passive House Institute. http://passipedia.org/passipedia_en/basics/the_passive_house_-_definition

Randers, J. (2012). 2052-A Global Forecast for the Next Forty Years. White River Jct., VT: Chelsea Green.

RESNET (2013). Mortgage Industry National Home Energy Rating Systems Standards. Oceanside, CA: Residential Energy Services Network.

Schneiders, J.; Feist, F.; Schulz, T.; Krick, B.; Rongen, L.; Wirtz, R. (2012). Passive Houses for Different Climate Zones. Passive House Institute and University of Innsbruck.

Shurcliff, W. (1982). Saunders Shrewsbury House: 100\% Solar Heating, Fully Automatic, Truly Low Cost. Self-published. 
Shurcliff, W. (1986). “Superinsulated Houses,” Annual Reviews Energy, vol. 11, pp. 1-24. Annual Reviews Inc.

Shurcliff, W. (1988). Superinsulated Houses and Air-to-Air Heat Exchangers. Andover, MA: Brickhouse Publishing Company.

Stecher, D.; Allison, K. (2012). Long-Term Results: New Construction Occupied Test House, Urbana, Illinois. Golden, CO: National Renewable Energy Laboratory. Accessed May 15, 2015: http://www.nrel.gov/docs/fy13osti/53707.pdf.

Stecher, D.; Klingenberg, K. (2008). "Design and Performance of the Smith House, a Passive House." NY-08-027, ASHRAE Conference Proceedings, New York.

Straube, J. (2009). "The Passive House (Passivhaus) Standard-A Comparison to Other Cold Climate Low-Energy Houses.” Westford, MA: Building Science Corporation, BSI-025. Accessed May 15, 2015: http://www.buildingscience.com/documents/insights/bsi-025-thepassivhaus-passive-house-standard.

Train, R.E.; Cahn, R.; MacDonald, G.J.F. (1970). The First Annual Report of the Council on Environmental Quality Together With the President's Message to Congress. Accessed May 15, 2015: http://www.slideshare.net/whitehouse/august-1970-environmental-quality-the-first-annualreport-of.

Wright, G. S.; Klingenberg, K. (2013). "Standard Adaptation: Upcoming Changes to PHIUS+ Certification," conference presentation, $8^{\text {th }}$ Annual North American Passive House Conference, Pittsburgh, PA, October 16, 2013. 


\section{Appendix A: Cost Optimization Calculation Protocol}

Table 17. PHIUS Technical Committee Resolutions

1. Intentionally left blank.

2. Whereas: RESNET defaults for energy use by "televisions and miscellaneous electric loads" are substantially higher than the current equivalent baseline defaults for "consumer electronics and small appliances" in WUFI Passive (the same goes for lighting). The formulas work a bit differently - the baseline formulas are strictly per person, whereas RESNET uses a combination of per-person and per-square foot terms (conditioned floor area, exterior dimensions). While occupants arguably "should be" using a lot less miscellaneous electricity, keeping low defaults is not an effective way of driving occupant behavior because the occupants are not being certified and there are no consequences to them. Rather, the standards influence the designer and unrealistically low defaults actually create a false incentive - they give too much latitude. Even so, it is reasonable to posit that passive building residents are to some degree, on average, more energy-conscious than usual. Also, current RESNET protocol is based on a five year old study which occurred at the peak of miscellaneous energy consumption.

Therefore:

For residential projects, the standard defaults for Miscellaneous Electrical and Lighting Demand will increase to (notionally) 80\% of RESNET levels (RESNET 2013).

3. Commenters opined that in doing economic analysis, climate is not the only thing that varies from place to place. Energy costs do as well. Because it is convenient to do in BEopt, it should be considered as well. Energy costs will be taken as the state average, or the openEI utility-byutility rates TBD, rather than national average.

4. The "optimal curve" data set includes both a reference case and a starting point. The reference case for the economic analysis is to always be the B10 benchmark ( IECC 2009, which is climate-dependent somewhat).

5. The starting point is that the building is constructed airtight (0.6 ACH50), with ducts inside, and is operated as a Passive House in that the occupants are credited with some awareness of how to operate interior blinds and natural ventilation. Also, the thermostat settings will be altered to $68 \mathrm{~F}$ winter $/ 77 \mathrm{~F}$ summer, that is justified because the windows are constrained for comfort. (Also the building is overinsulated and air-sealed.).

6. There will be no subsidizing performance upgrades by cheapening finishes. This strategy, while effective if you can get it on a project, is unfair to include in the studies.

7. To assure credibility, assumptions that may lead to skewed results, financial parameters particularly, should be avoided. Conservative values are assumed for the following parameters: Mortgage 30 years at $5.4 \%$, down payment $20 \%$, inflation $2.4 \%$, real discount rate $1.95 \%$, project time horizon 30 years, real escalation rate for electricity $1.04 \%$, real escalation rate for gas $0.64 \%$ (if needed, see point 13 ).

8. Knobs the optimizer is allowed to turn will include both passive measures and spaceconditioning equipment, to get a true picture on balancing the investment between the two. Update: Also solar hot water (40 or $64 \mathrm{sf}$ ) and the option of a $2 \mathrm{~kW} \mathrm{PV}$ array, to get a better sense of where the source energy is coming out.

9. Window technology is to be constrained by comfort considerations, climate-dependent. The 
solar heat gain coefficient will be the same on all sides of the study building as differential solar heat gain coefficient is considered impractical in the field.

10. Window area is to be fixed at $15 \%$ of wall area, which is equivalent to the BA benchmark.

11. Optimizer to be given some limited ability to choose window distribution: three choices equal N25, E25, S25, W25; northerly N40, E20, S20, W20; southerly N20, E20, S40, W20.

12. Winter shading reduction factor to be $0.8 * 0.95=0.76$. Summer shading reduction factor to be $0.8 *(0.2+0.7) / 2=0.36$.

13. Study building to be all-electric. Aligns with zero-ready.

14. Foundation to be slab on grade. (Basements were experimented with for hot-dry climate in a preliminary study. It made less difference to the upgraded house than to the benchmark and so was dropped.) Ceiling to be vented attic, cellulose.

15. Wall type to be exterior rigid foam. For appearances' sake, notionally EPS instead of polyiso. (stud wall + insulation)

16. Also for appearances sake, the study building is to be $26 \times 40$ feet instead of $26 \times 41$.

17. The statistical fractions of spa heaters, pool pumps etc. are removed from the study building. While they exist in the benchmark, it is simpler for the purposes of this study to zero them out.

Table 18. BEopt input-Options Screen, Example for Chicago

\begin{tabular}{|c|c|c|c|}
\hline Option & $\begin{array}{c}\text { Reference, B10 } \\
\text { Benchmark }\end{array}$ & Optimization Options & $\begin{array}{c}\text { Left at Reference, } \\
\text { Reset From } \\
\text { Reference, or } \\
\text { Knob }\end{array}$ \\
\hline \multicolumn{4}{|l|}{ Building } \\
\hline Orientation & North & North & Reference \\
\hline Neighbors & None & at 20 feet (east and west) & Reset \\
\hline \multicolumn{4}{|l|}{ General Operation } \\
\hline Heating Set Point & $71 \mathrm{~F}$ & $68 \mathrm{~F}$ & Reset \\
\hline Cooling Set Point & $76 \mathrm{~F}$ & $77 \mathrm{~F}$ & Reset \\
\hline Humidity Set Point & $60 \% \mathrm{RH}$ & $60 \% \mathrm{RH}$ & Reference \\
\hline Natural Ventilation & $\begin{array}{c}\text { Benchmark- } \\
\text { Monday } \\
\text { Wednesday } \\
\text { Friday }\end{array}$ & Year round & Reset \\
\hline Interior Shading & $\begin{array}{l}\text { Benchmark- } \\
\text { summer and } \\
\text { winter }=0.7\end{array}$ & Summer 0.36 , winter 0.76 & Reset \\
\hline \multicolumn{4}{|l|}{ Walls } \\
\hline Wood Stud & $\begin{array}{c}\text { R-13 fiberglass } \\
\text { Grade } 1,2 \times 416 \\
\text { in. o.c. }\end{array}$ & R-13 $2 \times 416$ in. o.c. & Reference \\
\hline Wall Sheathing & OSB+R5 XPS & OSB plus up to R-48 polyiso & Knob \\
\hline
\end{tabular}




\begin{tabular}{|c|c|c|c|}
\hline Option & $\begin{array}{c}\text { Reference, B10 } \\
\text { Benchmark }\end{array}$ & Optimization Options & $\begin{array}{c}\text { Left at Reference, } \\
\text { Reset From } \\
\text { Reference, or } \\
\text { Knob } \\
\end{array}$ \\
\hline \multicolumn{4}{|l|}{ Double Wood Stud } \\
\hline Exterior Finish & Vinyl, light (0.3) & Vinyl, light (0.3) & Reference \\
\hline \multicolumn{4}{|l|}{ Ceiling/Roof } \\
\hline Unfinished Attic & $\begin{array}{l}\text { R-38 cellulose, } \\
\text { vented }\end{array}$ & R-38 to R-120 cellulose, vented & Knob \\
\hline Roof Material & $\begin{array}{l}\text { asphalt shingles, } \\
\text { medium }(0.85)\end{array}$ & asphalt shingles medium, $(0.85)$ & Reference \\
\hline Radiant Barrier & None & None & Reference \\
\hline \multicolumn{4}{|l|}{ Foundation/Floors } \\
\hline Slab & $\begin{array}{l}\text { 2-ft R10 perim } \\
\text { R5 gap XPS }\end{array}$ & $\begin{array}{l}\text { perimeter/exterior options plus } \\
\text { whole-slab up to R40 }\end{array}$ & Knob \\
\hline Carpet & $80 \%$ Carpet & $80 \%$ Carpet & Reference \\
\hline \multicolumn{4}{|l|}{ Thermal Mass } \\
\hline Floor Mass & Wood surface & Wood surface or 2-in gyp crete & Knob \\
\hline Exterior Wall Mass & $1 / 2$ in. drywall & $\begin{array}{c}1 / 2 \text { in, } 5 / 8 \text {, or double } 1 / 2 \text { in. } \\
\text { drywall }\end{array}$ & Knob \\
\hline $\begin{array}{l}\text { Partition Wall } \\
\text { Mass }\end{array}$ & $1 / 2$ in. drywall & $\begin{array}{c}1 / 2 \text { in, } 5 / 8 \text {, or double } 1 / 2 \text { in. } \\
\text { drywall }\end{array}$ & Knob \\
\hline Ceiling Mass & $1 / 2$ in. drywall & $\begin{array}{c}1 / 2 \text { in, } 5 / 8 \text {, or double } 1 / 2 \text { in } \\
\text {.drywall }\end{array}$ & Knob \\
\hline \multicolumn{4}{|l|}{ Windows } \\
\hline Window Areas & $\begin{array}{l}15 \% \text { F25 B25 } \\
\text { L25 R25, } \\
\text { casement size }\end{array}$ & $\begin{array}{c}15 \% \text { F25 B25 L25 R25, F40 else } \\
20, \text { B40 else } 20\end{array}$ & Knob \\
\hline Window Tech & $\begin{array}{c}\text { Double pane } \\
U=0.35 \\
\text { Solar heat gain } \\
\text { coefficient }=0.44\end{array}$ & Triple pane: $U=0.18$ to 0.13 & Knob \\
\hline Eaves & $2 \mathrm{Ft}$ & $2 \mathrm{ft}$ or 3 foot & Knob \\
\hline Overhangs & None & $\begin{array}{c}\text { None } \\
2 \mathrm{ft} \text {, all stories, all windows } \\
2 \mathrm{ft}, 1 \text { st story, all windows } \\
2 \mathrm{ft} \text {, 1st story, back windows }(\mathrm{S})\end{array}$ & Knob \\
\hline \multicolumn{4}{|l|}{ Air flow } \\
\hline Air Leakage & $\begin{array}{c}7 \text { ACH50, } 0.5 \\
\text { shelter coefficient }\end{array}$ & Reference or 0.6 ACH50 & Reset \\
\hline $\begin{array}{l}\text { Mechanical } \\
\text { Ventilation }\end{array}$ & Exhaust & $\begin{array}{c}\text { Exhaust, HRV 60\%, HRV 70\%, } \\
\text { ERV }^{\mathrm{a}} 83 \% \text {, ERV } 92 \%\end{array}$ & Knob \\
\hline \multicolumn{4}{|l|}{ Space Conditioning } \\
\hline $\begin{array}{l}\text { Air source heat } \\
\text { pump }\end{array}$ & $\begin{array}{c}\text { SEER }^{\mathrm{b}} \text { 13, } \mathrm{HSPF}^{\mathrm{c}} \\
7.7\end{array}$ & None & Reset \\
\hline
\end{tabular}




\begin{tabular}{|c|c|c|c|}
\hline Option & $\begin{array}{c}\text { Reference, B10 } \\
\text { Benchmark }\end{array}$ & Optimization Options & $\begin{array}{c}\text { Left at Reference, } \\
\text { Reset From } \\
\text { Reference, or } \\
\text { Knob } \\
\end{array}$ \\
\hline Electric baseboard & None & $100 \%$ efficient & Reset \\
\hline Ducts & $15 \%$ leakage, $\mathrm{R}-8$ & In finished space & Reset \\
\hline $\begin{array}{l}\text { Mini-split heat } \\
\text { pump }\end{array}$ & None & $\begin{array}{l}\text { SEER 14.5, 8.2 HSPF, } \\
\text { SEER 21, 10.7 HSPF, or } \\
\text { SEER 27, 11.5 HSPF }\end{array}$ & Knob \\
\hline Ceiling Fan & Benchmark & Hi efficiency & Reset \\
\hline Dehumidifier & None & None, or autosize standalone & Knob \\
\hline \multicolumn{4}{|l|}{ Water heating } \\
\hline Water heater & $\begin{array}{c}\text { Electric } \\
\text { benchmark }\end{array}$ & $\begin{array}{c}\text { Electric } 0.92,0.95 \text {, or } 0.99 \\
\text { tankless, heat pump water heater } \\
50 \text { gal } 140^{\circ} \mathrm{F} \text { inside, heat pump } \\
\text { water heater } 80 \text { gal inside }\end{array}$ & Knob \\
\hline Distribution & $\begin{array}{l}\text { Uninsulated, } \\
\text { trunk-branch, } \\
\text { copper }\end{array}$ & $\begin{array}{l}\text { R-2, trunk-branch, copper, } \\
\text { demand-recirculating }\end{array}$ & Reset \\
\hline $\begin{array}{c}\text { Solar Water } \\
\text { Heating }\end{array}$ & None & None, $40 \mathrm{ft}^{2}, 64 \mathrm{ft}^{2}$ & Knob \\
\hline Lighting & $\begin{array}{c}\text { Benchmark } \\
(1,764 \mathrm{kWh} / \mathrm{yr})\end{array}$ & $\begin{array}{c}767 \mathrm{kWh} / \mathrm{yr}(80 \% \text { RESNET }), \\
\text { costs for } 100 \% \text { compact } \\
\text { fluorescent lamps }\end{array}$ & Reset \\
\hline \multicolumn{4}{|l|}{ Major Appliances } \\
\hline Refrigerator & $\begin{array}{l}\text { Benchmark } \\
(434 \mathrm{kWh} / \mathrm{yr})\end{array}$ & $384 \mathrm{kWh} / \mathrm{yr}$ & Reset \\
\hline Cooking Range & $\begin{array}{l}\text { Benchmark } \\
\text { (electric) }\end{array}$ & Benchmark (electric) & Reference \\
\hline Dishwasher & Benchmark & $318 \mathrm{kWh} / \mathrm{yr}$ & Reset \\
\hline Clothes Washer & Benchmark & ENERGY STAR & Reset \\
\hline Clothes Dryer & $\begin{array}{l}\text { Benchmark } \\
\text { (electric) }\end{array}$ & Electric & Reference \\
\hline \multicolumn{4}{|l|}{ Miscellaneous } \\
\hline $\begin{array}{l}\text { Other Electric } \\
\text { Loads }\end{array}$ & $\begin{array}{c}\text { Benchmark } \\
(2,228 \mathrm{kWh} / \mathrm{yr})\end{array}$ & 2,048 kWh/yr (80\% RESNET) & Reset \\
\hline $\begin{array}{l}\text { Other Hot Water } \\
\text { Loads }\end{array}$ & Benchmark & Benchmark & Reference \\
\hline \multicolumn{4}{|l|}{ Power Generation } \\
\hline PV System & None & None or $2 \mathrm{~kW}$ & Knob \\
\hline
\end{tabular}

${ }^{a}$ Energy recovery ventilator

${ }^{b}$ Seasonal energy-efficiency ratio

${ }^{\mathrm{c}}$ Heating season performance factor 
Table 19. BEopt Input, Geometry Screen

$40 \times 26 \mathrm{ft}, 2$ stories, above grade, short side south (same for all locations). First floor 9 feet high, second floor 10 feet high.

\begin{tabular}{c|c|c|c}
\hline Input & Value & Units & \\
\hline Total Finished Floor Area & 2,080 & $\mathrm{ft}^{2}$ & $\begin{array}{c}(\text { Nominal treated floor area } \\
\left.1,560 \mathrm{ft}^{2}\right)\end{array}$ \\
\hline Bedrooms & 3 & & \\
Baths & 2 & & \\
\hline
\end{tabular}

\section{Custom BEopt Options and Cost Overrides}

The only cost override used was on HRV/ERV cost (higher). Window cost, ceiling, wall insulation and slab insulation costs were extrapolated for higher performing options. The exterior-foam wall assembly was given two increments in labor cost to represent attaching multiple layers of rigid foam.

\section{Ventilator Cost Data}

Built-in BEopt options for HRVs and ERVs were limited and the costs seemed too low, so the following data were collected mostly by Internet search. (Model names have been anonymized; the first four entries are built-in BEopt options.) Because the performance depends on both the thermal and electrical efficiency, it is not obvious at a glance how to rank the options. A preliminary optimization run was done in BEopt on this factor alone. A subset of eight choices on and near the optimal path was selected for use in the main study. Those entries are bulleted. The listed cost includes BEopt's default $\$ 618$ for installation labor.

Table 20. Ventilator Cost Data

\begin{tabular}{c|c}
\hline Option & $\begin{array}{c}\text { Cost } \\
\text { (Material + Labor) }\end{array}$ \\
\hline$\bullet \quad$ Exhaust & $\$ 245$ \\
\hline HRV, 70\%, 60\% & $\$ 914.34$ \\
$\bullet \quad$ ERV, 72\% & $\$ 914.34$ \\
\hline HRV 65, 0.86 W/cfm & $\$ 878.65$ \\
\hline ERV 67, 0.86 W/cfm & $\$ 1,401$ \\
\hline ERV 67, 0.46 W/cfm & $\$ 1,567$ \\
\hline ERV 71, 0.93 W/cfm & $\$ 2,522$ \\
$\bullet \quad$ HRV 71, 0.63 W/cfm & $\$ 1,748$ \\
\hline$\quad$ HRV 75, 0.49 W/cfm & $\$ 1,517$ \\
\hline HRV 82, 1.01 W/cfm & $\$ 2,243$ \\
\hline$\quad$ ERV 83, 0.72 W/cfm & $\$ 2,759$ \\
\hline$\quad$ HRV 88, 0.31 W/cfm & $\$ 2,718$ \\
\hline$\quad$ HRV 91, 0.29 W/cfm & $\$ 4,413$ \\
\hline
\end{tabular}




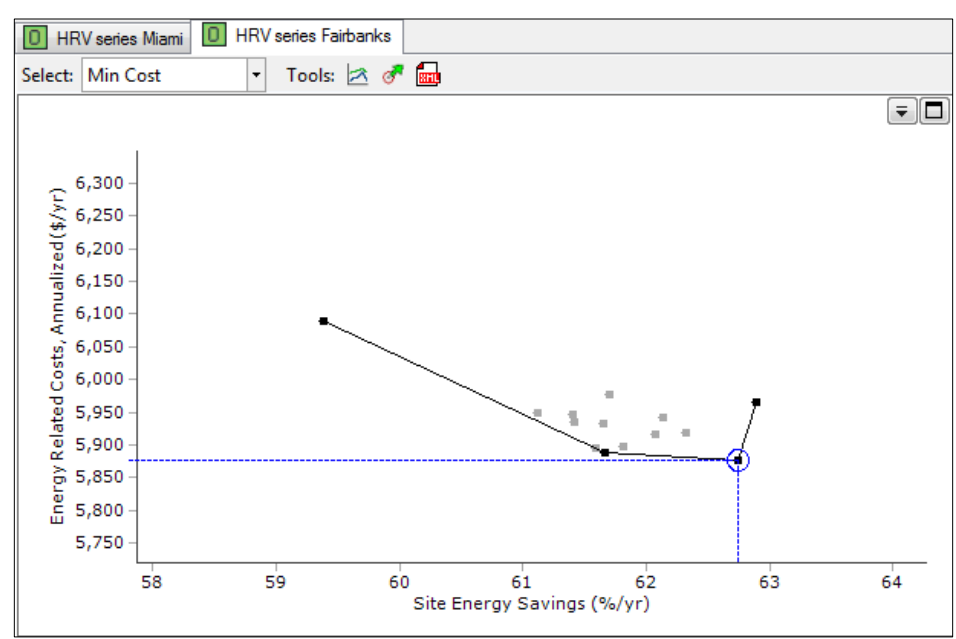

Figure 25. Preliminary optimization run to screen ventilator options

\section{Window Cost Extrapolation}

The extrapolation to higher-performing windows is shown here.

Insulated frame, BEopt data

whole

\begin{tabular}{crrr} 
panes SHGC & window U & $\mathrm{R}$ & \$/sf window \\
\hline 2 hi & 0.32 & 3.13 & 15.3 \\
2 med & 0.3 & 3.33 & 16.79 \\
2 lo & 0.29 & 3.45 & 17.96 \\
2 hi & 0.29 & 3.45 & 18.31 \\
2 med & 0.27 & 3.70 & 21.5 \\
2 lo & 0.26 & 3.85 & 24.06 \\
3 hi & 0.21 & 4.76 & 45.95 \\
3 lo & 0.19 & 5.26 & 57.35 \\
3 hi & 0.18 & 5.56 & 66.63 \\
3 lo & 0.17 & 5.88 & 68.45
\end{tabular}

Extrapolate

$\begin{array}{rrr}0.16 & 6.25 & 77.97 \\ 0.15 & 6.67 & 86.82 \\ 0.14 & 7.14 & 96.93 \\ 0.13 & 7.69 & 108.59 \\ 0.12 & 8.33 & 122.20 \\ 0.11 & 9.09 & 138.29\end{array}$




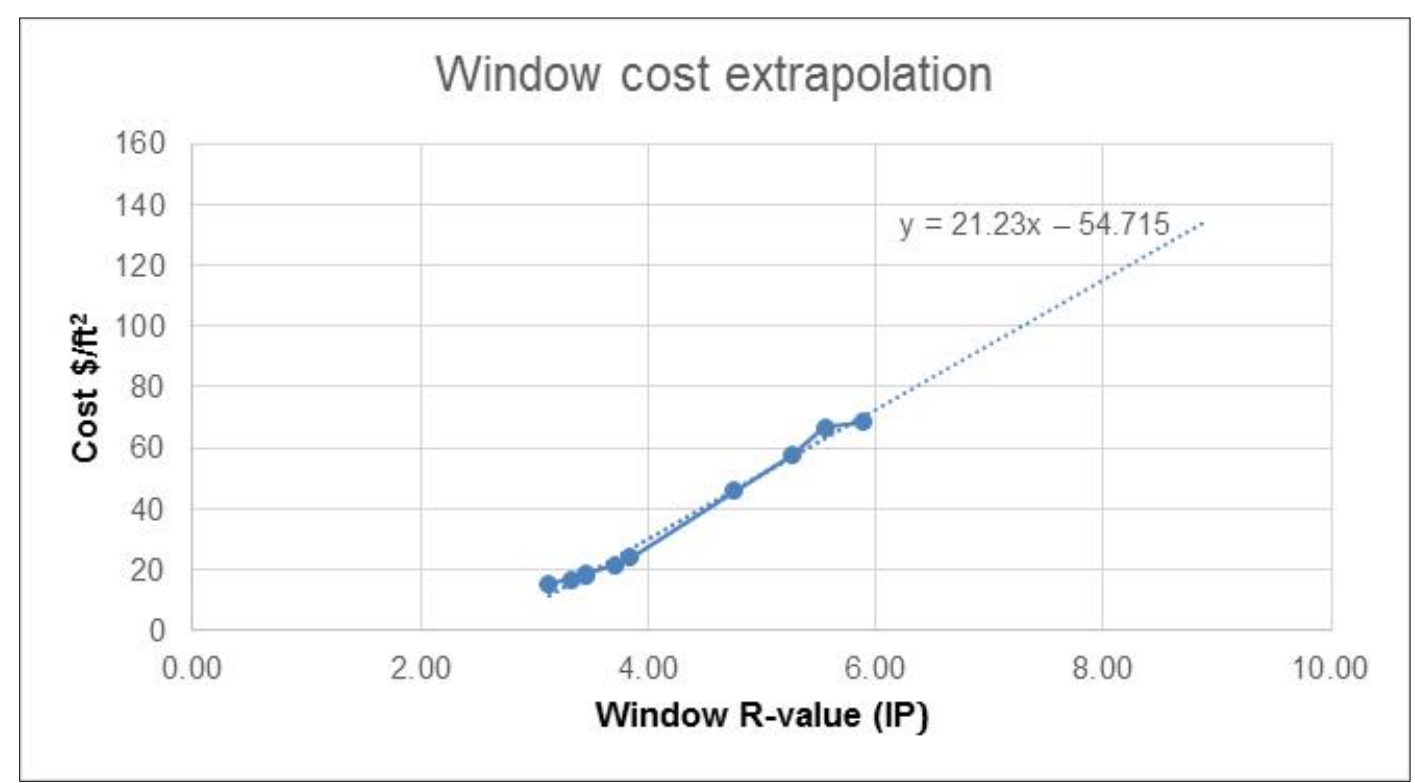

Figure 26. Cost extrapolation for windows 


\section{Appendix B: Cost Curves and BEopt Output for Four Example Locations}

Black arrows indicate the chosen "cost-competitive" points.

\section{San Francisco, California (zone 3C)}

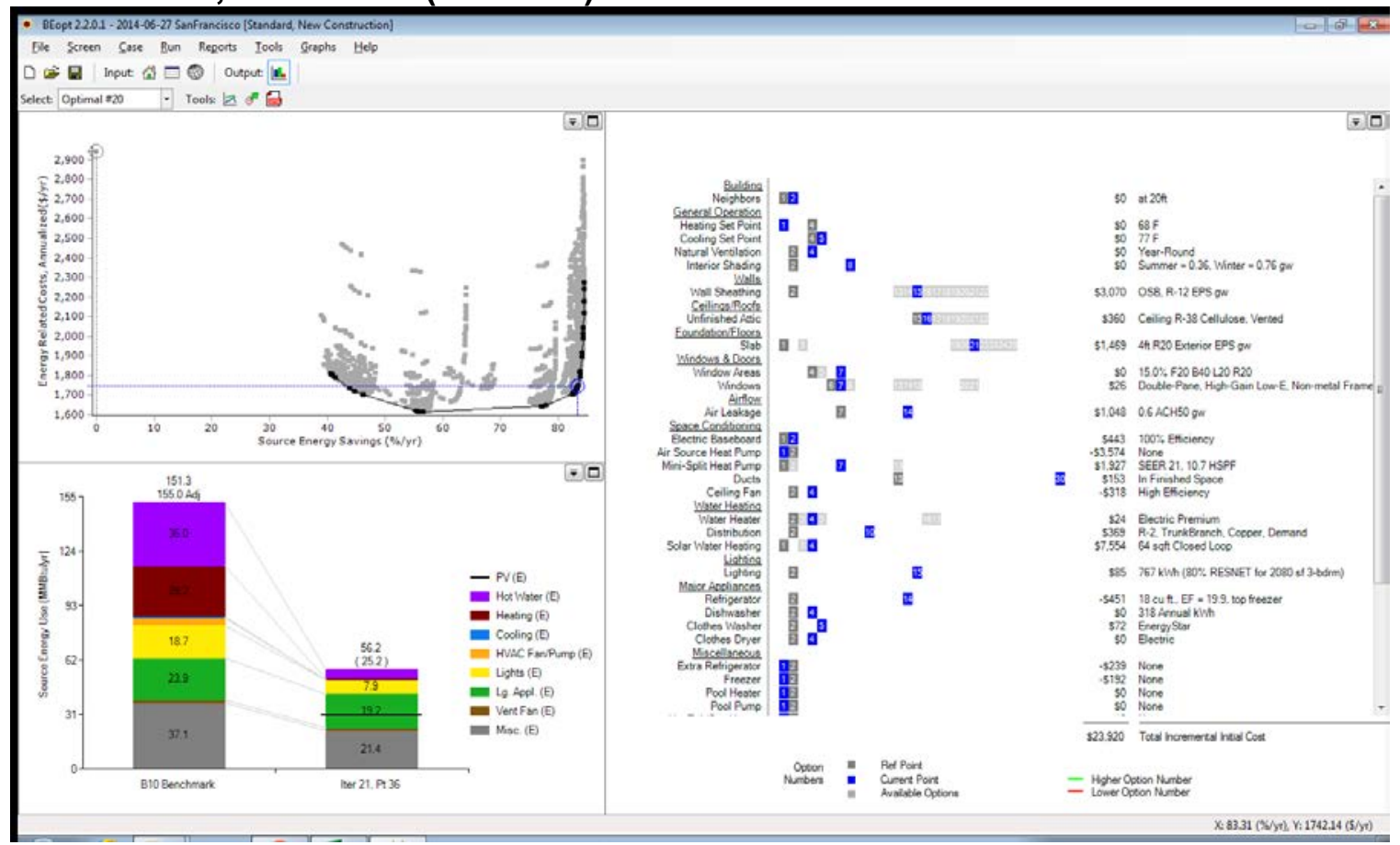

\section{Case: San Francisco CA}

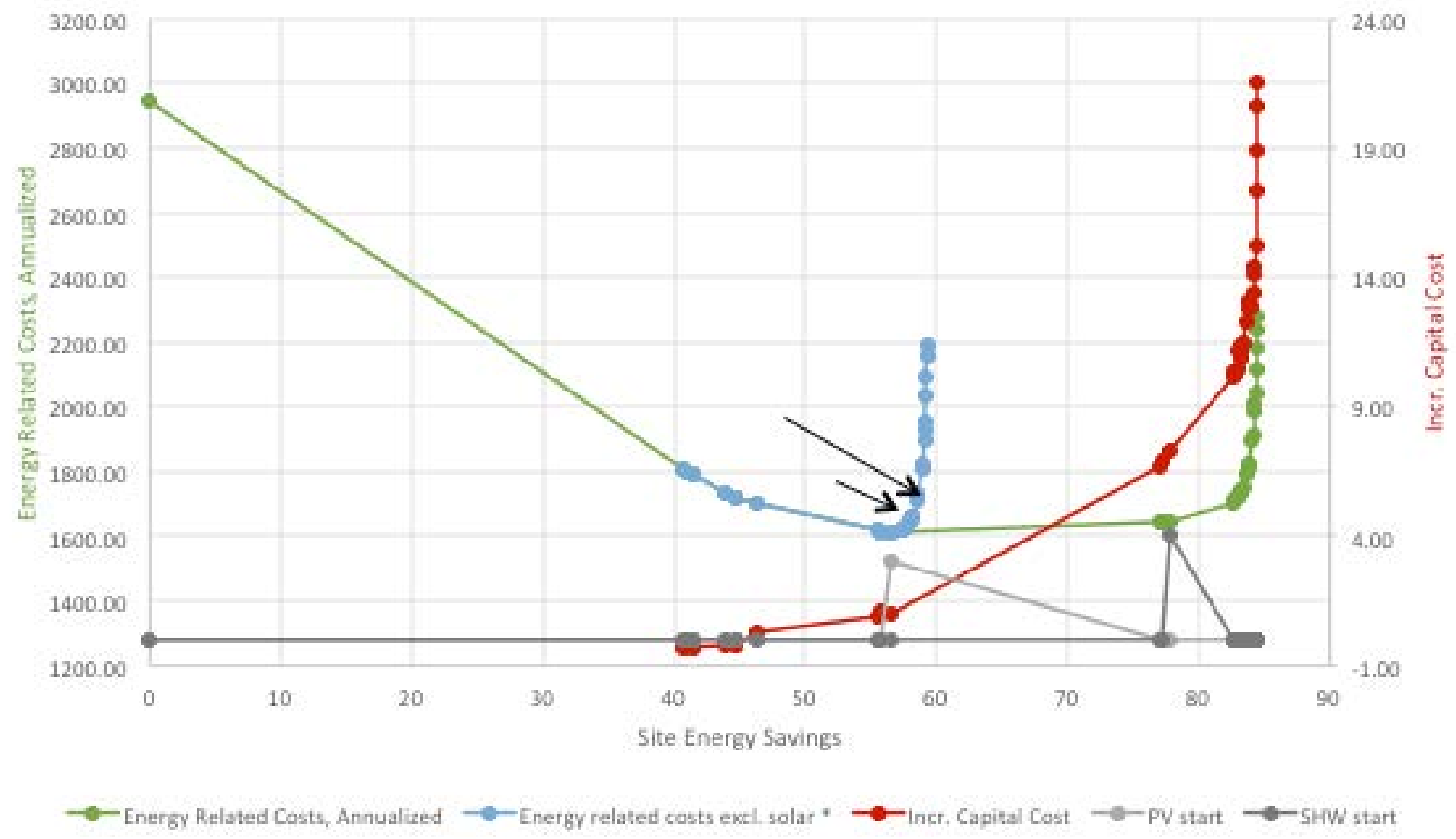


\begin{tabular}{l|l} 
U.S. DEPARTMENT OF & Energy Efficiency \& \\
Renewable Energy
\end{tabular}

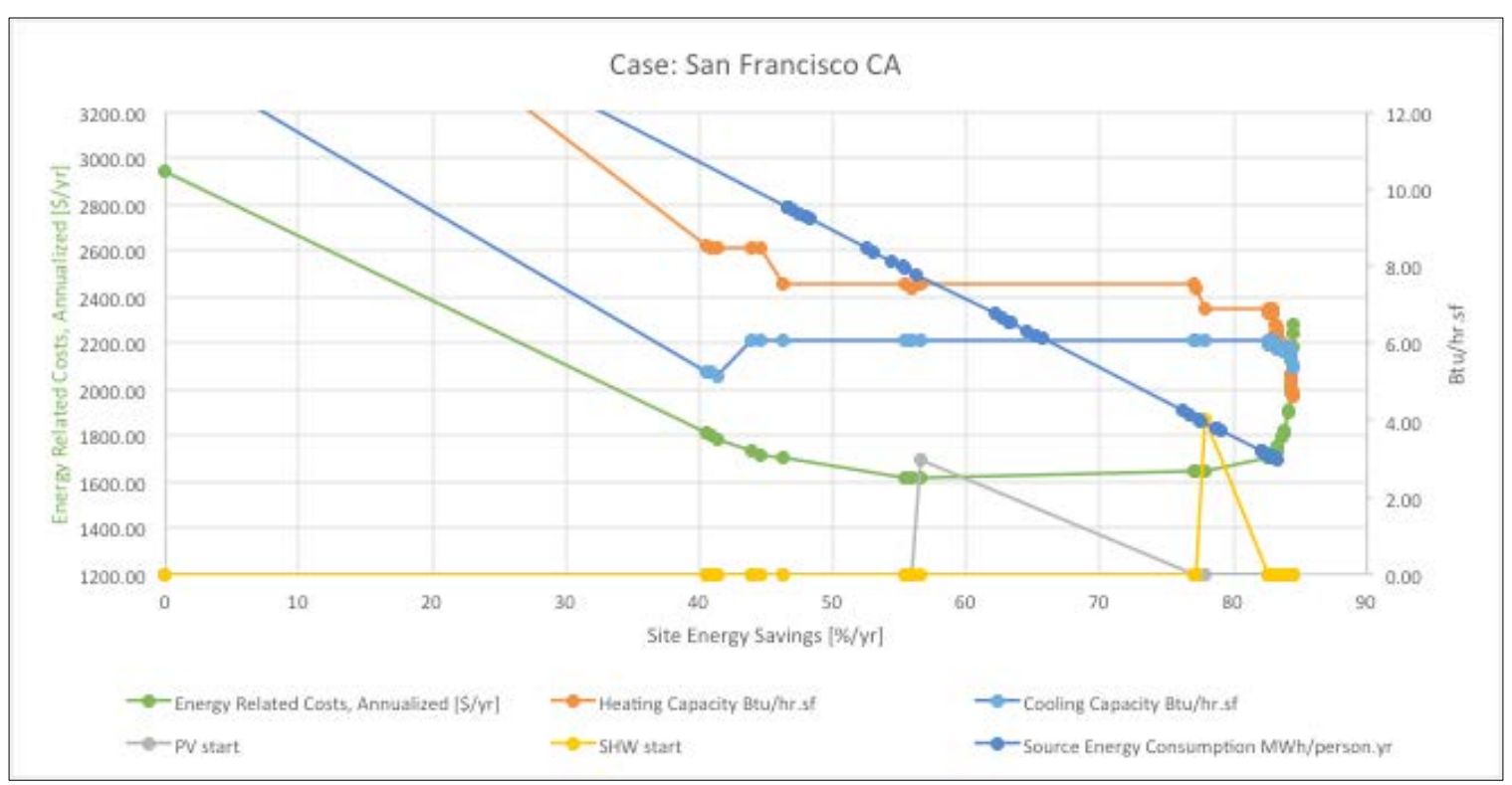




\section{Houston, Texas (zone 2A)}

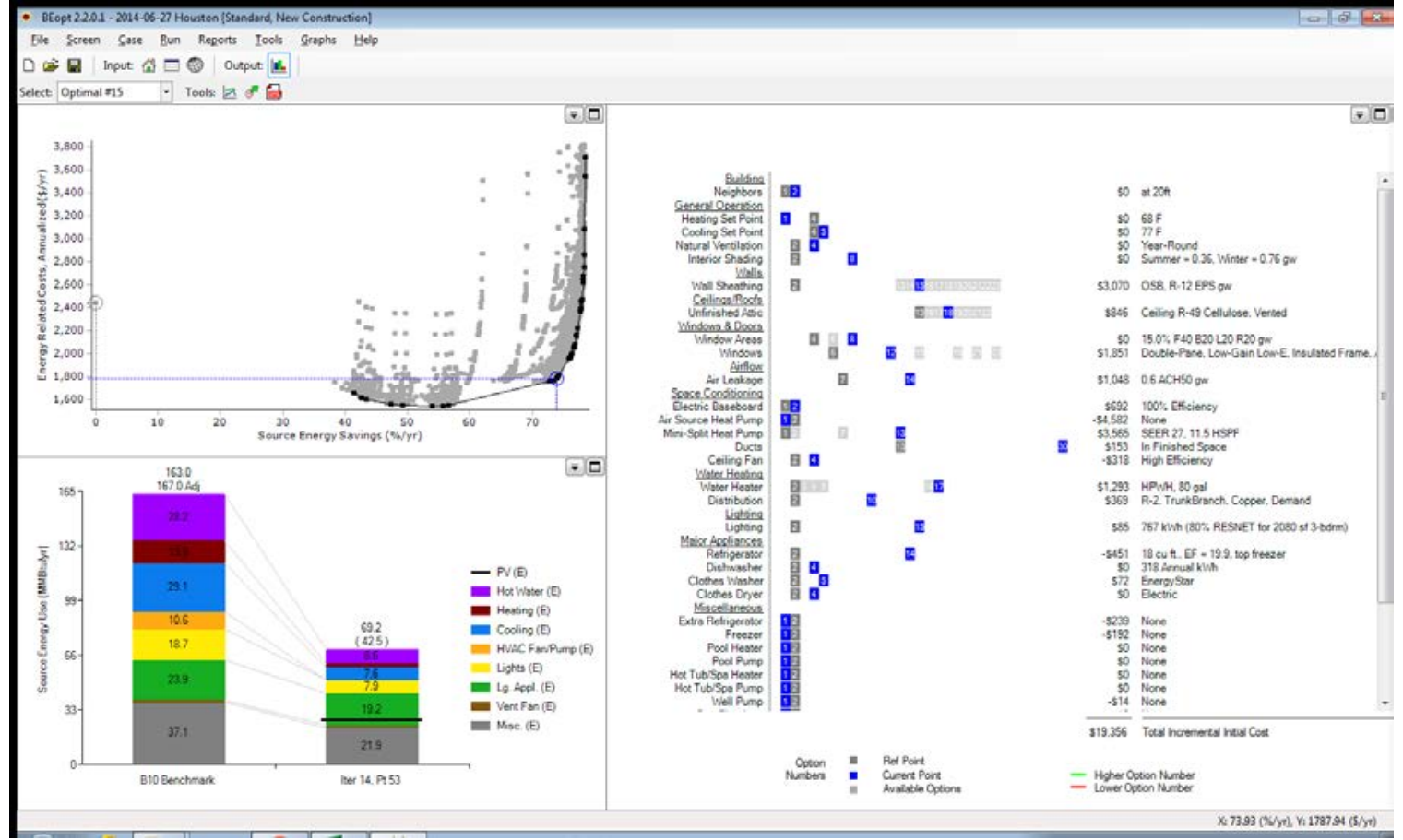

\section{Case: Houston TX}

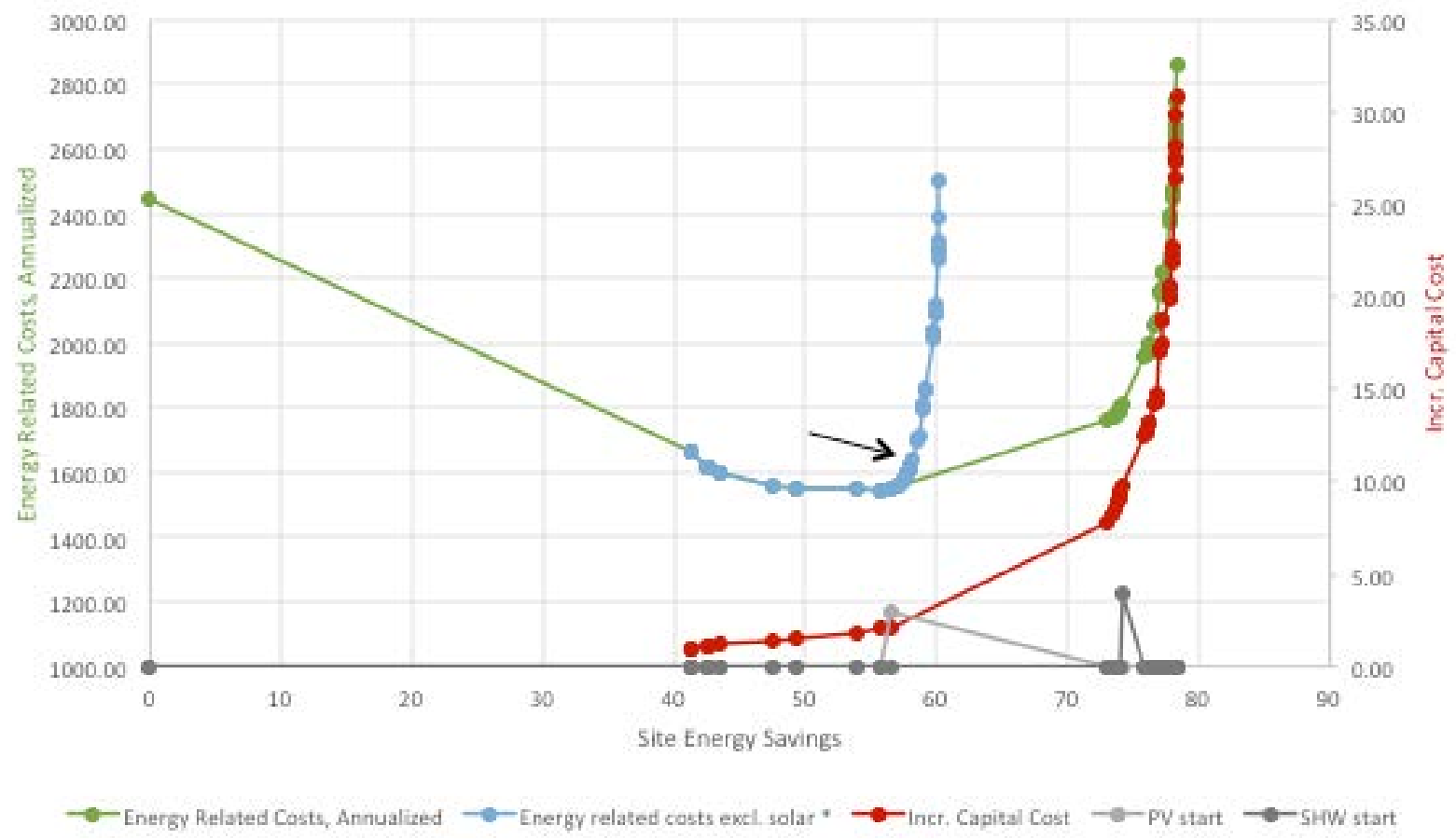




\section{Portland, Oregon (zone 4C)}

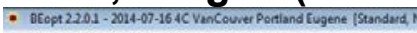

Die Screen Sare Bun Reports Iools Graphs Heo

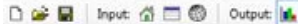

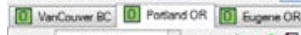

Select Optimal s18 - Took 1200
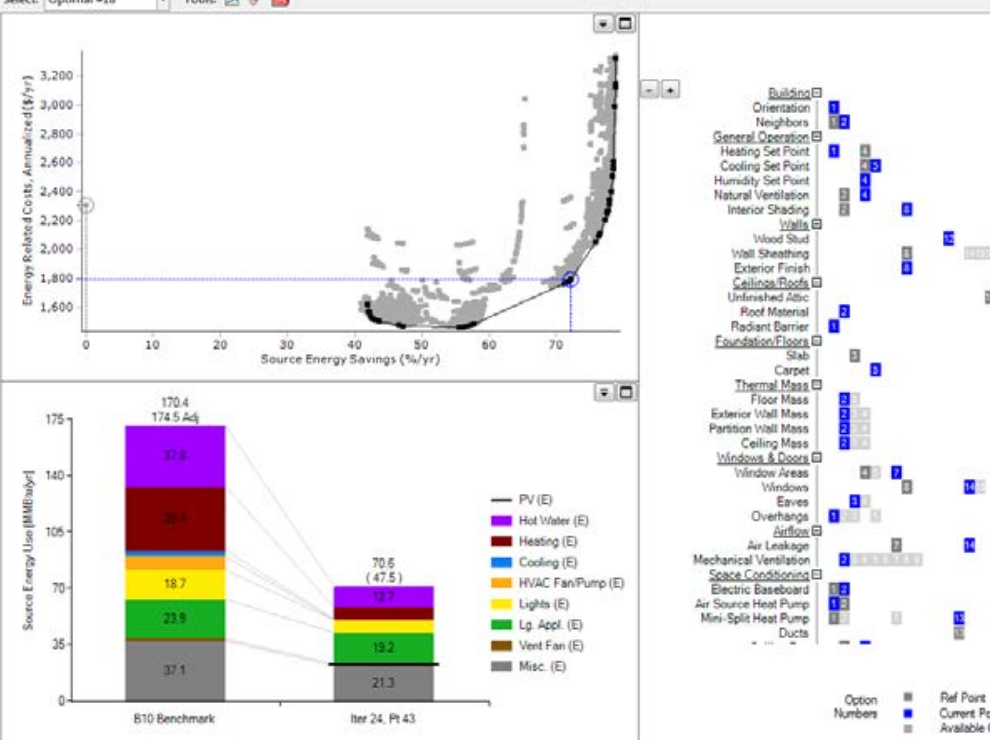

II

m $\mathbb{x}$
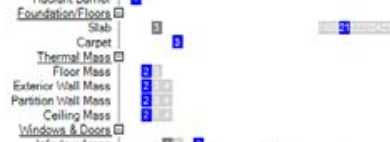

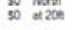

50
50 $7 F$

${ }_{50}$ Yex: Pround

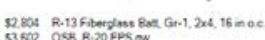

S3.60 OSB R.20 EPS

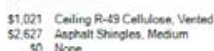

80 Nore

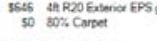

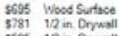

$\$ 5695,1 / 2$ in Orwall

50. 1501: F20 E00 L20 R2O

Fin Fto

50 None

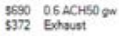

s778 100 . Ellitiency

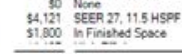

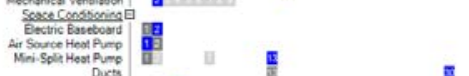

Wodon : Rad Port

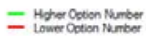

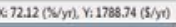

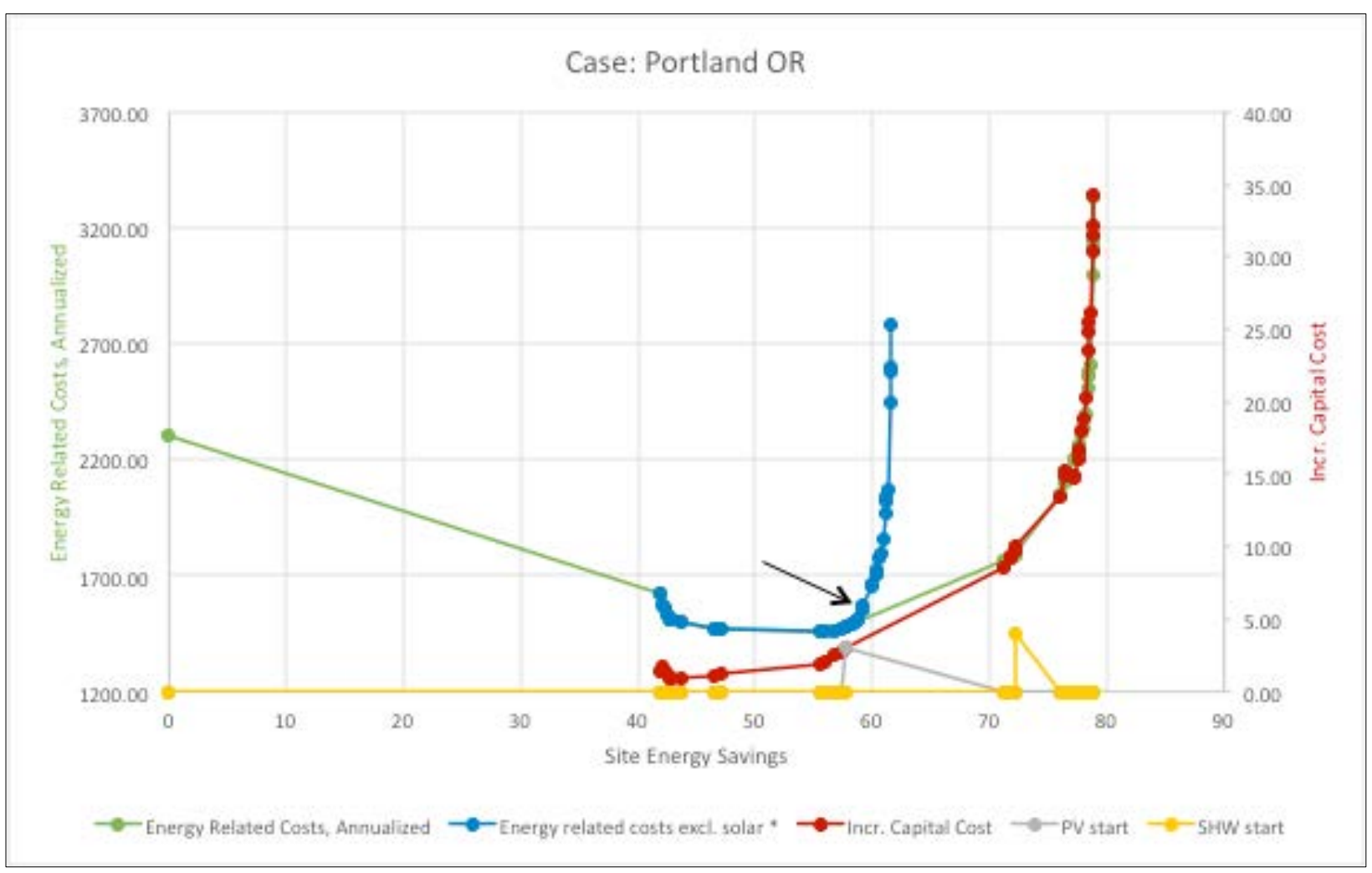




\section{Energy Efficiency \& \\ Renewable Energy}

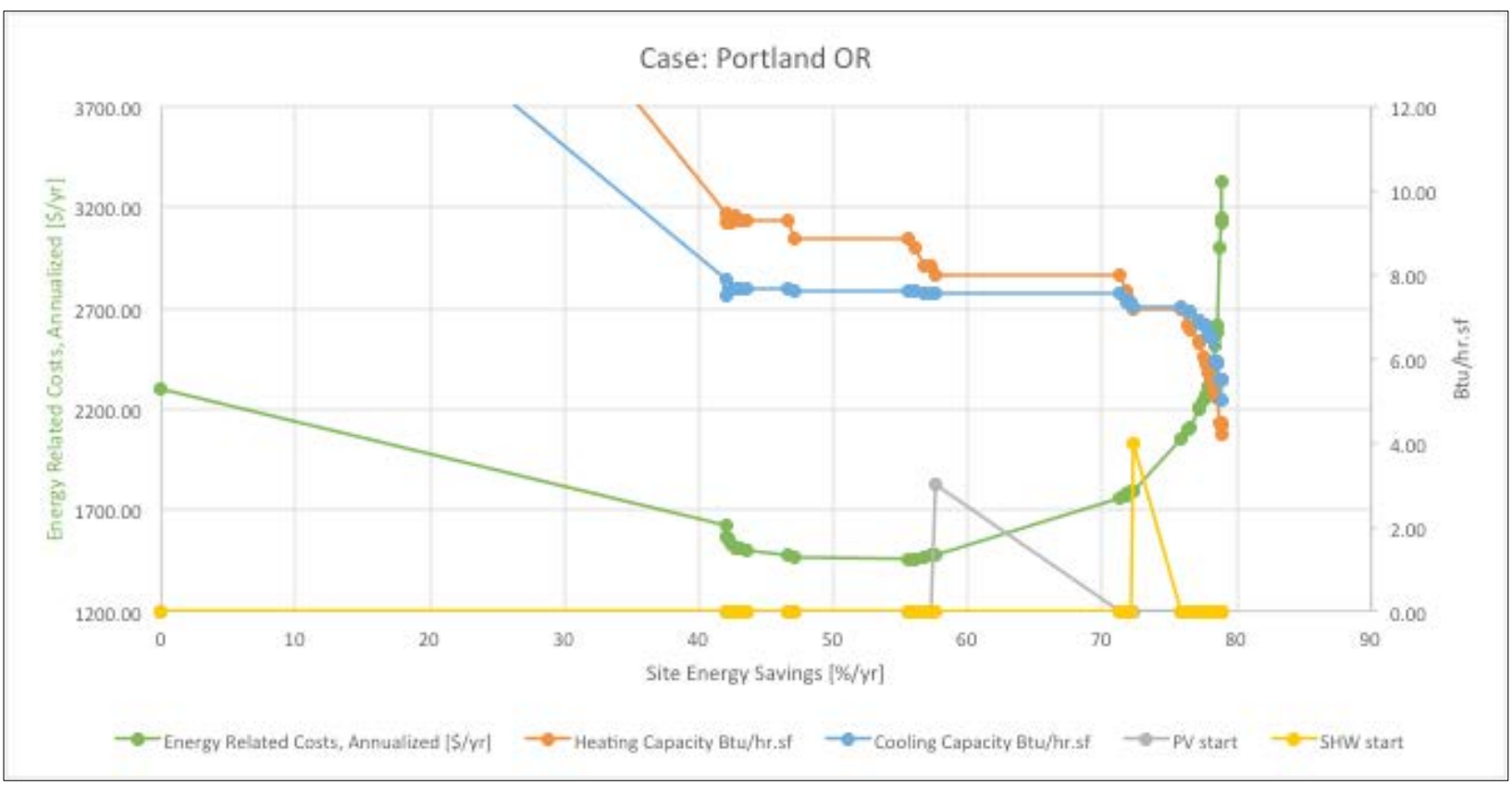




\section{Edmonton, Alberta (zone 7)}

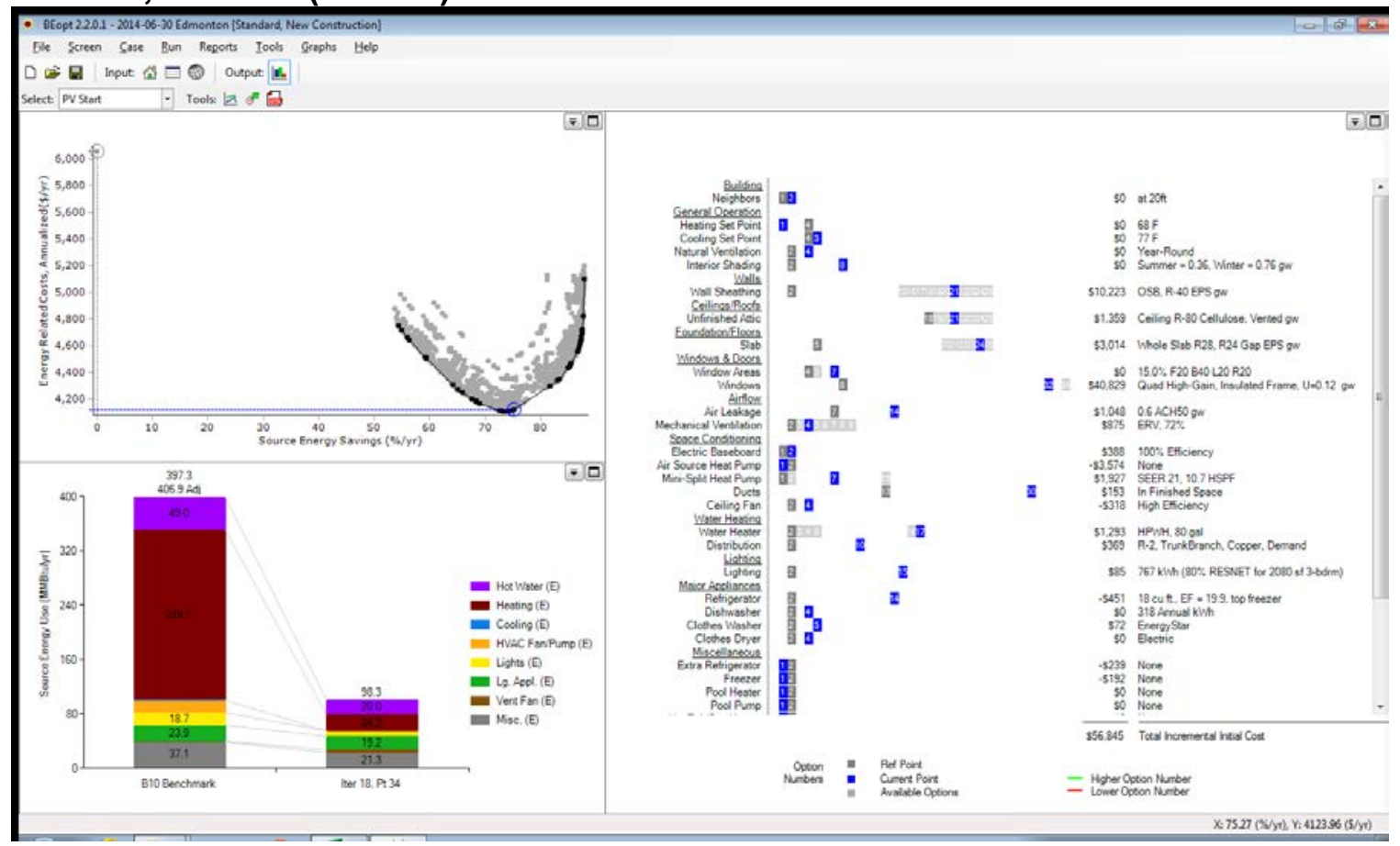

\section{Case: Edmonton $\mathrm{AB}$}

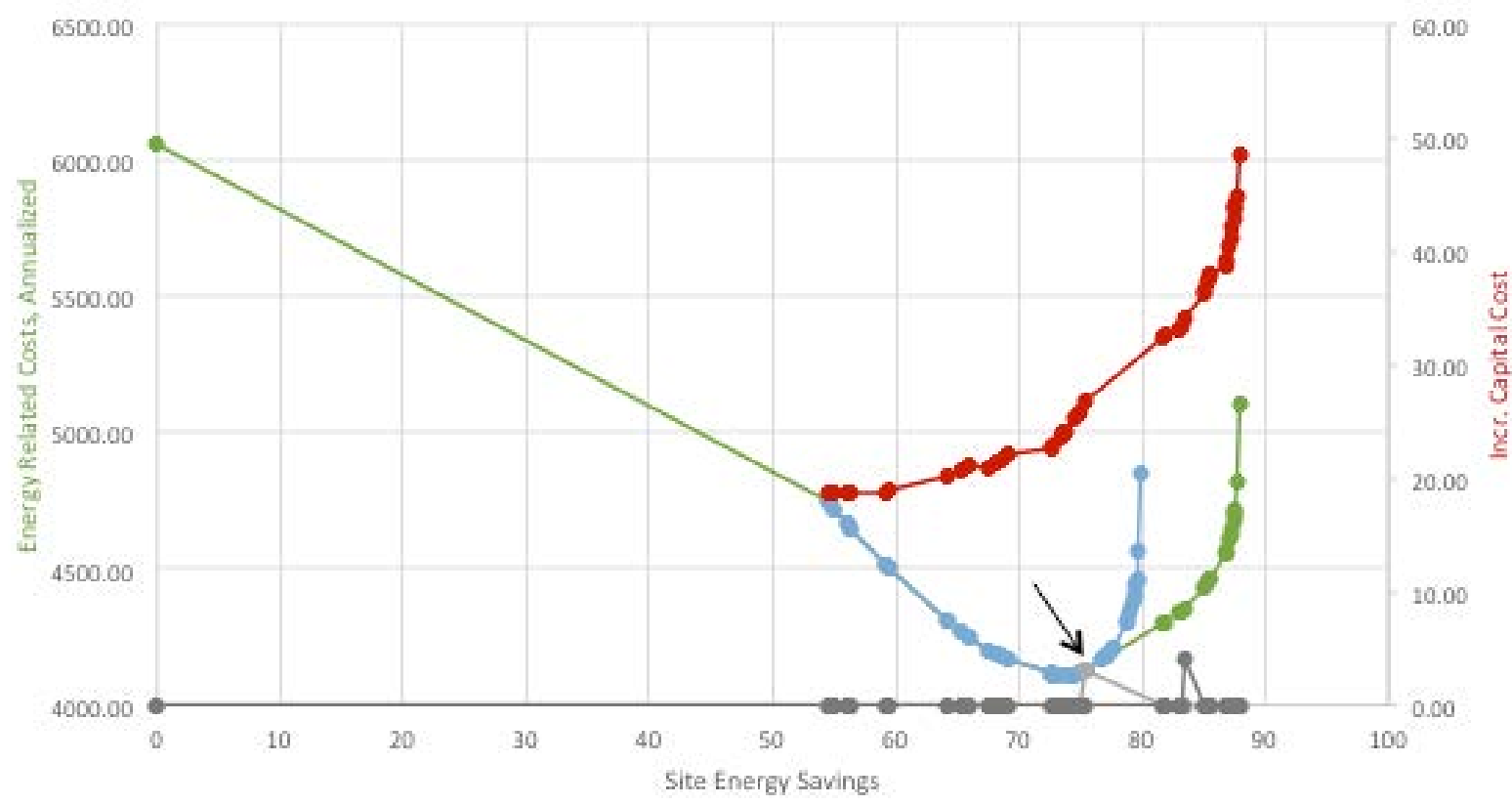

- Energy Related Costs, Annualized - - Energy related costs excl. solar * - - Incr. Capital Cost - - PV start - - SHW start 


\section{Appendix C: Space Conditioning Data Table}

\begin{tabular}{|c|c|c|c|c|c|c|c|c|c|c|c|c|c|c|c|c|c|}
\hline Zone & City & State & 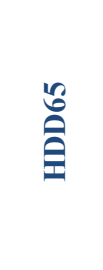 & $\begin{array}{l}\text { Ů } \\
\stackrel{0}{0}\end{array}$ & 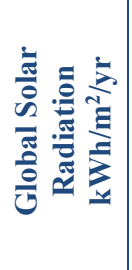 & 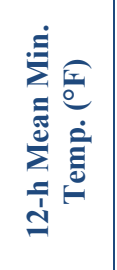 & 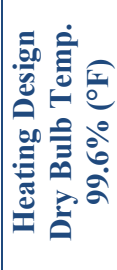 & 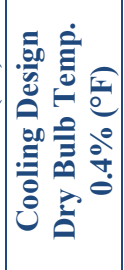 & 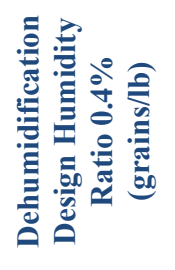 & 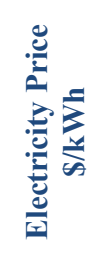 & 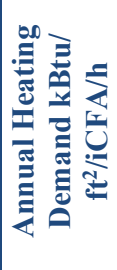 & 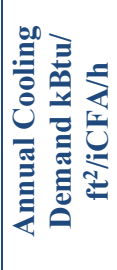 & 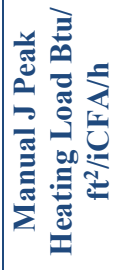 & 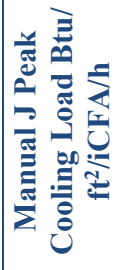 & 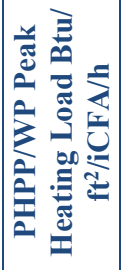 & 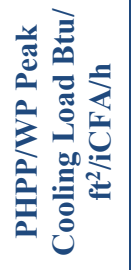 & 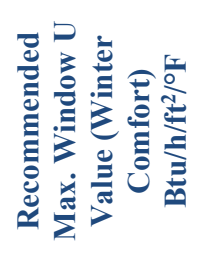 \\
\hline 7 & Calgary & $\mathrm{AB}$ & 9093 & 64 & 1480 & -17.32 & -19.8 & 83.5 & 83.1 & 0.1228 & 7.8 & 1.0 & 7.8 & 4.7 & 4.7 & 3.3 & 0.13 \\
\hline 7 & Edmonton & $\mathrm{AB}$ & 9356 & 121 & 1314 & -25.6 & -20.5 & 83 & 89.7 & 0.1206 & 8.4 & 1.0 & 7.8 & 4.7 & 4.7 & 3.3 & 0.12 \\
\hline 7 & Anchorage & AK & 10121 & 5 & 894 & -9.4 & -9.3 & 71.5 & 68.2 & 0.1663 & 9.5 & 1.0 & 6.4 & 3.5 & 3.9 & 2.4 & 0.14 \\
\hline 8 & Fairbanks & $\mathrm{AK}$ & 13517 & 72 & 935 & -35.5 & -43.5 & 81.3 & 74.1 & 0.1663 & 12.0 & 1.0 & 8.3 & 4.4 & 5.0 & 3.1 & 0.10 \\
\hline $3 A$ & Birmingham & $\mathrm{AL}$ & 2653 & 2014 & 1607 & 13.46 & 20.5 & 95.5 & 138.7 & 0.1068 & 2.9 & 8.4 & 6.1 & 7.4 & 3.7 & 5.2 & 0.20 \\
\hline $2 \mathrm{~A}$ & Mobile & $\mathrm{AL}$ & 1652 & 2499 & 1643 & 24.08 & 27.7 & 93.8 & 146.6 & 0.1068 & 2.1 & 10.9 & 5.8 & 7.4 & 3.5 & 5.2 & 0.25 \\
\hline 3A & Little Rock & AR & 3158 & 1938 & 1637 & 9.5 & 18.5 & 95.4 & 138.9 & 0.0858 & 3.3 & 8.1 & 6.3 & 7.3 & 3.8 & 5.1 & 0.18 \\
\hline 5B & Flagstaff & $\mathrm{AZ}$ & 6830 & 123 & 1900 & -9.4 & 3.9 & 85.7 & 93.2 & 0.1054 & 5.4 & 1.0 & 6.6 & 5.0 & 3.9 & 3.5 & 0.14 \\
\hline 2B & Phoenix & $\mathrm{AZ}$ & 923 & 4626 & 2094 & \#N/A & 38.7 & 110.3 & 120.1 & 0.1054 & 1.0 & 16.1 & 5.1 & 12.3 & 3.0 & 8.6 & \#N/A \\
\hline 2B & Tucson & $\mathrm{AZ}$ & 1416 & 3273 & 2065 & 30.02 & 31.6 & 106 & 118.7 & 0.1054 & 1.0 & 11.3 & 5.5 & 9.9 & 3.3 & 7.0 & 0.28 \\
\hline $4 C$ & Vancouver & $\mathrm{BC}$ & 5225 & 80 & 1268 & 21.02 & 20.9 & 77.3 & 84.4 & 0.1027 & 5.5 & 1.0 & 5.6 & 4.2 & 3.4 & 2.9 & 0.23 \\
\hline 3B & Fresno & CA & 2266 & 2097 & 1883 & 29.48 & 31.4 & 103.5 & 94.7 & 0.1419 & 1.8 & 5.7 & 5.1 & 8.2 & 3.0 & 5.8 & 0.28 \\
\hline 3B & Los Angeles & CA & 1295 & 582 & 1827 & $\# \mathrm{~N} / \mathrm{A}$ & 44.5 & 83.7 & 101.6 & 0.1419 & 1.2 & 1.8 & 4.3 & 5.0 & 2.6 & 3.5 & \#N/A \\
\hline 3B & Sacramento & $\mathrm{CA}$ & 2495 & 1213 & 1804 & 31.64 & 31.1 & 100.1 & 88.9 & 0.1419 & 2.1 & 3.1 & 5.1 & 7.0 & 3.0 & 4.9 & 0.30 \\
\hline 3B & San Diego & CA & 1197 & 673 & 1878 & \#N/A & 44.8 & 83.1 & 104.7 & 0.1419 & 1.0 & 2.2 & 4.3 & 4.9 & 2.6 & 3.5 & \#N/A \\
\hline $3 \mathrm{C}$ & San Francisco & CA & 2689 & 144 & 1718 & $\# \mathrm{~N} / \mathrm{A}$ & 39.1 & 82.8 & 80.8 & 0.1419 & 2.5 & 1.0 & 4.4 & 4.6 & 2.7 & 3.2 & \#N/A \\
\hline 5B & Bouldo & $\mathrm{CO}$ & 5667 & 721 & 1639 & -1.48 & -1.4 & 93.9 & 94.7 & 0.1021 & 5.1 & 2.0 & 7.2 & 6.0 & 4.3 & 4.2 & 0.16 \\
\hline 5B & $\begin{array}{l}\text { Colorado } \\
\text { Springs }\end{array}$ & $\mathrm{CO}$ & 6160 & 459 & 1675 & 2.3 & 1.3 & 90.4 & 95.5 & 0.1021 & 5.4 & 1.3 & 6.9 & 5.6 & 4.1 & 3.9 & 0.16 \\
\hline $5 \mathbf{A}$ & Hartford & CT & 5935 & 765 & 1370 & 5.54 & 4.1 & 91.4 & 124.3 & 0.1626 & 5.5 & 3.0 & 6.3 & 6.1 & 3.8 & 4.3 & 0.17 \\
\hline $4 \mathrm{~A}$ & Wilmington & $\mathrm{DE}$ & 4756 & 1142 & 1479 & -9.22 & 13.3 & 91.9 & 133.3 & 0.1271 & 4.6 & 4.7 & 6.1 & 6.4 & 3.6 & 4.5 & 0.14 \\
\hline $2 \mathrm{~A}$ & Daytona Beach & FL & 748 & 2992 & 1774 & 25.16 & 35.6 & 92.8 & 144.2 & 0.1081 & 1.1 & 12.7 & 5.3 & 7.4 & 3.2 & 5.2 & 0.25 \\
\hline $2 \mathrm{~A}$ & Jacksonville & FL & 1327 & 2632 & 1658 & 21.56 & 29.4 & 94.6 & 142.9 & 0.1081 & 1.8 & 11.1 & 5.7 & 7.6 & 3.4 & 5.3 & 0.23 \\
\hline $1 \mathrm{~A}$ & Key West & FL & 70 & 4832 & 1320 & $\# \mathrm{~N} / \mathrm{A}$ & 54.3 & 90.9 & 152 & 0.1081 & 1.5 & 21.4 & 4.1 & 7.7 & 2.4 & 5.4 & \#N/A \\
\hline $1 \mathrm{~A}$ & Miami & FL & 126 & 4537 & 1754 & $\# \mathrm{~N} / \mathrm{A}$ & 47.6 & 91.8 & 148.1 & 0.1081 & 1.0 & 19.6 & 4.5 & 7.8 & 2.7 & 5.5 & \#N/A \\
\hline
\end{tabular}




\begin{tabular}{|c|c|c|c|c|c|c|c|c|c|c|c|c|c|c|c|c|c|}
\hline Zone & City & State & $\begin{array}{l}\mathscr{O} \\
\hat{\widehat{E}}\end{array}$ & 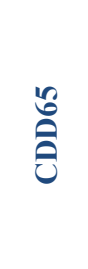 & 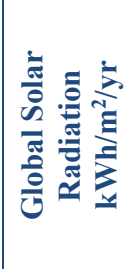 & 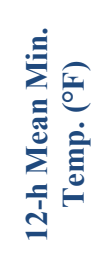 & 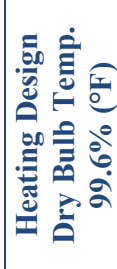 & 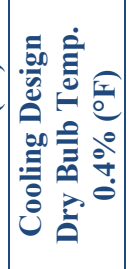 & 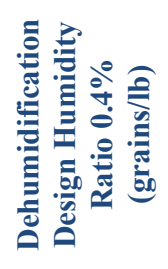 & 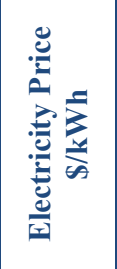 & 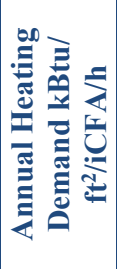 & 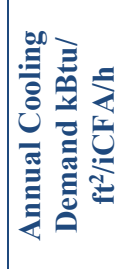 & 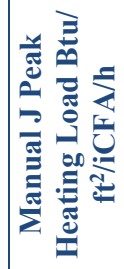 & 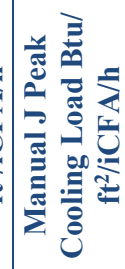 & 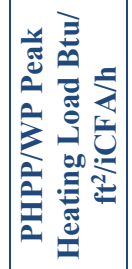 & 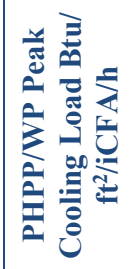 & 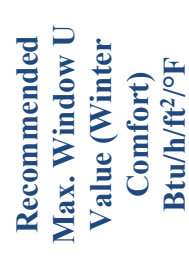 \\
\hline $2 \mathrm{~A}$ & Tampa & FL & 527 & 3563 & 1814 & $\# \mathrm{~N} / \mathrm{A}$ & 38.8 & 92.6 & 147.7 & 0.1081 & 1.0 & 15.5 & 5.1 & 7.6 & 3.1 & 5.3 & $\# \mathrm{~N} / \mathrm{A}$ \\
\hline $\mathbf{3 A}$ & Atlanta & GA & 2671 & 1893 & 1687 & 12.74 & 21.5 & 93.9 & 133.1 & 0.1030 & 2.8 & 7.5 & 6.1 & 7.0 & 3.6 & 4.9 & 0.20 \\
\hline $3 A$ & Macon & GA & 2263 & 2179 & 1683 & 19.58 & 23.9 & 96.9 & 138.3 & 0.1030 & 2.5 & 9.0 & 6.0 & 7.7 & 3.6 & 5.4 & 0.22 \\
\hline $2 \mathrm{~A}$ & Savannah & GA & 1761 & 2455 & 1677 & 25.52 & 27.4 & 95.5 & 146.1 & 0.1030 & 2.1 & 10.7 & 5.8 & 7.7 & 3.5 & 5.4 & 0.25 \\
\hline $1 \mathrm{~A}$ & Honolulu & $\mathrm{HI}$ & 0 & 4679 & 1925 & $\# \mathrm{~N} / \mathrm{A}$ & 62 & 89.8 & 131.2 & 0.3600 & 1.0 & 17.8 & 1.5 & 7.2 & 0.9 & 5.0 & $\# \mathrm{~N} / \mathrm{A}$ \\
\hline $5 \mathrm{~A}$ & Des Moines & IA & 6172 & 1034 & 1531 & -4.9 & -5.3 & 92.5 & 138.7 & 0.0995 & 5.7 & 4.5 & 7.4 & 6.5 & 4.4 & 4.6 & 0.15 \\
\hline 5B & Boise & ID & 5453 & 957 & 1619 & 5.72 & 8.7 & 98.6 & 77.5 & 0.0773 & 5.1 & 2.1 & 6.7 & 6.5 & 4.0 & 4.6 & 0.17 \\
\hline $5 \mathrm{~A}$ & Chicago & IL & 6209 & 864 & 1380 & -5.44 & -1.5 & 91.4 & 133.3 & 0.1032 & 6.0 & 3.6 & 7.1 & 6.3 & 4.3 & 4.4 & 0.15 \\
\hline $5 \mathbf{A}$ & Fort Wayne & IN & 5991 & 825 & 1391 & -5.26 & -0.7 & 90.8 & 134.5 & 0.0961 & 5.9 & 3.5 & 7.1 & 6.2 & 4.3 & 4.3 & 0.15 \\
\hline $5 \mathrm{~A}$ & Indianapolis & IN & 5272 & 1087 & 1503 & -5.26 & 2 & 91 & 136.8 & 0.0961 & 5.1 & 4.6 & 7.1 & 6.3 & 4.2 & 4.4 & 0.15 \\
\hline $4 \mathrm{~A}$ & Wichita & KS & 4464 & 1682 & 1686 & 4.1 & 7.4 & 100.1 & 134.2 & 0.1031 & 4.1 & 6.8 & 6.8 & 7.8 & 4.1 & 5.5 & 0.17 \\
\hline $4 \mathrm{~A}$ & Lexington & $\mathrm{KY}$ & 4567 & 1201 & 1475 & -2.74 & 8.3 & 91.6 & 132.6 & 0.0866 & 4.7 & 4.9 & 6.8 & 6.4 & 4.1 & 4.5 & 0.15 \\
\hline $4 \mathrm{~A}$ & Louisville & $\mathrm{KY}$ & 4201 & 1459 & 1347 & 1.04 & 9.7 & 93.3 & 136 & 0.0866 & 4.7 & 6.0 & 6.8 & 6.8 & 4.1 & 4.7 & 0.16 \\
\hline $2 \mathrm{~A}$ & New Orleans & LA & 1286 & 2925 & 1632 & 27.86 & 33.1 & 93.8 & 150.6 & 0.0772 & 2.0 & 13.0 & 5.7 & 7.7 & 3.4 & 5.4 & 0.27 \\
\hline $5 \mathrm{~A}$ & Boston & MA & 5596 & 750 & 1408 & -1.66 & 8.1 & 90.6 & 122 & 0.1365 & 5.3 & 2.9 & 6.2 & 6.0 & 3.7 & 4.2 & 0.16 \\
\hline $4 \mathrm{~A}$ & Baltimore & $\mathrm{MD}$ & 4552 & 1261 & 1490 & 8.42 & 14 & 94 & 133.2 & 0.1208 & 4.5 & 5.1 & 6.1 & 6.7 & 3.7 & 4.7 & 0.18 \\
\hline $5 \mathrm{~A}$ & Detroit & MI & 5989 & 884 & 1304 & 2.12 & 5.2 & 90.7 & 126.3 & 0.1294 & 5.9 & 3.5 & 6.4 & 6.1 & 3.9 & 4.3 & 0.16 \\
\hline $5 \mathrm{~A}$ & Grand Rapids & MI & 6615 & 639 & 1388 & -10.66 & 2.2 & 89.4 & 128.2 & 0.1294 & 6.1 & 2.7 & 6.5 & 5.9 & 3.9 & 4.1 & 0.14 \\
\hline 7 & & $\mathrm{MN}$ & 9325 & 210 & 1342 & -22 & -17.9 & 84.3 & 114.4 & 0.1010 & 8.4 & 1.0 & 7.7 & 5.1 & 4.6 & 3.6 & 0.12 \\
\hline 7 & $\begin{array}{c}\text { International } \\
\text { Falls }\end{array}$ & $\mathrm{MN}$ & 9944 & 218 & 1261 & -28.48 & -26.1 & 86.1 & 113.9 & 0.1010 & 9.1 & 1.0 & 8.2 & 5.3 & 4.9 & 3.7 & 0.11 \\
\hline $6 \mathrm{~A}$ & Minneapolis & $\mathrm{MN}$ & 7472 & 765 & 1401 & -19.12 & -11.2 & 90.9 & 128.3 & 0.1010 & 6.9 & 3.1 & 7.6 & 6.1 & 4.6 & 4.3 & 0.12 \\
\hline $4 \mathrm{~A}$ & Kansas City & $\mathrm{MO}$ & 5012 & 1372 & 1588 & 1.4 & 2 & 95.8 & 145.3 & 0.0934 & 4.8 & 6.1 & 7.1 & 7.2 & 4.3 & 5.0 & 0.16 \\
\hline $4 \mathrm{~A}$ & Springfield & $\mathrm{MO}$ & 4442 & 1366 & 1587 & 1.04 & 6.6 & 94.8 & 135.6 & 0.0934 & 4.3 & 5.6 & 6.9 & 6.9 & 4.1 & 4.8 & 0.16 \\
\hline $4 \mathrm{~A}$ & St. Louis & $\mathrm{MO}$ & 4436 & 1650 & 1533 & 1.04 & 6.6 & 95.5 & 140.6 & \begin{tabular}{|l|}
0.0934 \\
\end{tabular} & 4.5 & 7.0 & 6.9 & 7.2 & 4.1 & 5.1 & 0.16 \\
\hline $\mathbf{3 A}$ & Jackson & MS & 2282 & 2294 & 1682 & 18.32 & 23.2 & 96.4 & 142.9 & 0.0954 & 2.5 & 9.8 & 6.1 & 7.7 & 3.6 & 5.4 & 0.22 \\
\hline 6B & Billings & MT & 6705 & 630 & 1504 & -7.24 & -9.4 & 94.8 & 89.3 & 0.0914 & 6.2 & 1.7 & 7.7 & 6.0 & 4.6 & 4.2 & 0.14 \\
\hline
\end{tabular}




\begin{tabular}{|c|c|c|c|c|c|c|c|c|c|c|c|c|c|c|c|c|c|}
\hline Zone & City & State & $\begin{array}{l}\mathscr{0} \\
\hat{\widehat{O}}\end{array}$ & ஜ̊̊̊ & 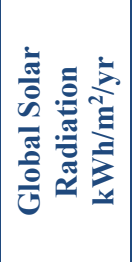 & 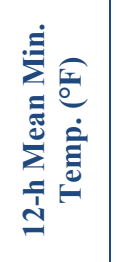 & 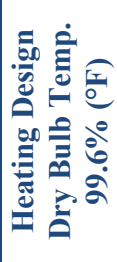 & 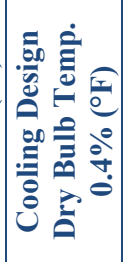 & 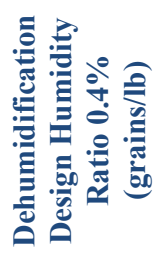 & 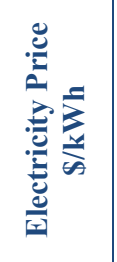 & 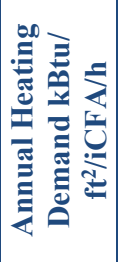 & 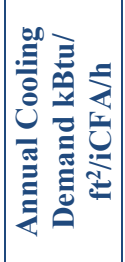 & 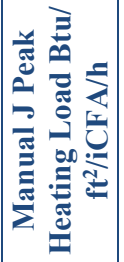 & 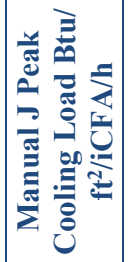 & 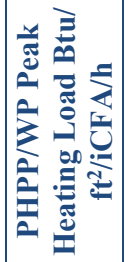 & 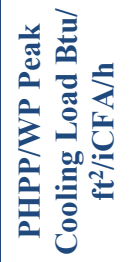 & 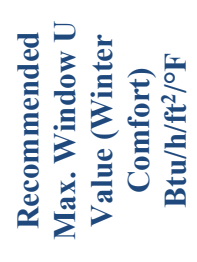 \\
\hline $6 B$ & Helena & MT & 7545 & 395 & 1461 & -9.58 & -13 & 92.9 & 83.7 & 0.0914 & 6.9 & 1.0 & 7.8 & 5.7 & 4.7 & 4.0 & 0.14 \\
\hline $4 \mathrm{~A}$ & Asheville & $\mathrm{NC}$ & 4144 & 844 & 1577 & 13.1 & 14.7 & 88.3 & 125.8 & 0.1010 & 4.1 & 3.3 & 6.3 & 5.8 & 3.8 & 4.1 & 0.20 \\
\hline $3 \mathbf{A}$ & Charlotte & $\mathrm{NC}$ & 3065 & 1713 & 1633 & 19.58 & 21 & 94.3 & 130.8 & 0.1010 & 3.2 & 6.7 & 6.0 & 7.0 & 3.6 & 4.9 & 0.22 \\
\hline $4 \mathrm{~A}$ & Raleigh & $\mathrm{NC}$ & 3275 & 1666 & 1590 & 13.28 & 19.6 & 94.8 & 134.8 & 0.1010 & 3.4 & 6.8 & 6.1 & 7.1 & 3.7 & 4.9 & 0.20 \\
\hline $6 \mathrm{~A}$ & Bismarck & ND & 8396 & 546 & 1440 & -20.02 & -18.5 & 93.9 & 121.3 & 0.0810 & 7.7 & 2.2 & 8.1 & 6.3 & 4.9 & 4.4 & 0.12 \\
\hline $5 \mathbf{A}$ & Grand Island & $\mathrm{NE}$ & 6081 & 1037 & 1605 & -7.96 & -4.3 & 95.7 & 136.2 & 0.0924 & 5.5 & 4.4 & 7.4 & 6.9 & 4.4 & 4.8 & 0.14 \\
\hline $5 \mathrm{~A}$ & Omaha & $\mathrm{NE}$ & 5981 & 1093 & 1532 & -5.26 & -6.1 & 94 & 135.3 & 0.0924 & 5.6 & 4.6 & 7.6 & 6.7 & 4.5 & 4.7 & 0.15 \\
\hline $4 \mathrm{~A}$ & Atlantic City & NJ & 4913 & 1014 & 1480 & 13.64 & 11.4 & 92.2 & 132.5 & 0.1466 & 4.6 & 4.2 & 6.0 & 6.4 & 3.6 & 4.5 & 0.20 \\
\hline $6 \mathrm{~A}$ & Saint Johns & NL & 8727 & 54 & 1169 & 3.92 & 4.3 & 76.3 & 100.1 & 0.1118 & 8.3 & 1.0 & 6.1 & 4.3 & 3.7 & 3.0 & 0.17 \\
\hline 4B & Albuquerque & $\mathrm{NM}$ & 3994 & 1370 & 1926 & 20.66 & 18.2 & 95.3 & 100 & 0.1011 & 3.3 & 4.0 & 6.1 & 6.6 & 3.6 & 4.6 & 0.23 \\
\hline $5 B$ & Elko & $\mathrm{NV}$ & 7115 & 358 & 1722 & -13 & -4.1 & 94.6 & 74.9 & 0.1098 & 6.0 & 1.0 & 7.1 & 5.7 & 4.2 & 4.0 & 0.13 \\
\hline 3B & Las Vegas & $\mathrm{NV}$ & 2015 & 3486 & 2034 & 28.58 & 31 & 108.4 & 103 & 0.1098 & 1.5 & 10.4 & 5.4 & 10.5 & 3.2 & 7.3 & 0.27 \\
\hline 5B & Reno & NV & 5043 & 791 & 1833 & 1.4 & 12.1 & 96.3 & 76 & 0.1098 & 4.2 & 1.7 & 6.2 & 6.1 & 3.7 & 4.3 & 0.16 \\
\hline $5 \mathrm{~A}$ & Albany & NY & 6562 & 619 & 1408 & 0.5 & -0.9 & 89.2 & 122.5 & 0.1634 & 5.8 & 2.4 & 6.5 & 5.8 & 3.9 & 4.1 & 0.16 \\
\hline $5 \mathbf{A}$ & Buffalo & NY & 6584 & 590 & 1359 & 3.2 & 3 & 88 & 124.6 & 0.1634 & 6.0 & 2.4 & 6.2 & 5.7 & 3.7 & 4.0 & 0.17 \\
\hline $4 \mathrm{~A}$ & New York City & NY & 4555 & 1259 & 1438 & 6.44 & 13.9 & 92.4 & 127.9 & 0.1634 & 4.3 & 4.9 & 5.8 & 6.5 & 3.5 & 4.5 & 0.18 \\
\hline $5 \mathrm{~A}$ & Syracuse & NY & 6577 & 594 & 1366 & -1.48 & -1.2 & 89.2 & 121.1 & 0.1634 & 5.9 & 2.3 & 6.5 & 5.8 & 3.9 & 4.0 & 0.16 \\
\hline $5 \mathrm{~A}$ & Cleveland & $\mathrm{OH}$ & 5850 & 774 & 1377 & -1.84 & 4.1 & 89.7 & 127.3 & 0.1078 & 5.7 & 3.1 & 6.7 & 6.0 & 4.0 & 4.2 & 0.15 \\
\hline $5 \mathrm{~A}$ & Columbus & $\mathrm{OH}$ & 5255 & 1015 & 1392 & 0.14 & 5 & 91.1 & 129.1 & 0.1078 & 5.3 & 4.1 & 6.8 & 6.2 & 4.1 & 4.4 & 0.16 \\
\hline $3 \mathbf{A}$ & Oklahoma City & $\mathrm{OK}$ & 3487 & 2047 & 1620 & 9.86 & 12.5 & 99.5 & 130 & 0.0871 & 3.6 & 7.9 & 6.7 & 7.9 & 4.0 & 5.6 & 0.19 \\
\hline $3 \mathbf{A}$ & Tulsa & OK & 3455 & 2051 & 1661 & 6.8 & 13.2 & 99.4 & 136.6 & 0.0871 & 3.5 & 8.4 & 6.7 & 8.0 & 4.0 & 5.6 & 0.18 \\
\hline $6 \mathrm{~A}$ & Ottawa & $\mathrm{ON}$ & 8142 & 428 & 1377 & -15.16 & -11.5 & 87.1 & 115.7 & 0.1406 & 7.2 & 1.6 & 7.2 & 5.5 & 4.3 & 3.8 & 0.13 \\
\hline $5 \mathrm{~A}$ & Toronto & ON & 7006 & 526 & 1381 & 0.86 & -0.5 & 88.5 & 119.7 & 0.1380 & 6.4 & 2.1 & 6.6 & 5.7 & 4.0 & 4.0 & 0.16 \\
\hline $4 C$ & Astoria & OR & 4949 & 20 & 1185 & 27.86 & 27.5 & 76.9 & 81.4 & 0.0906 & 5.6 & 1.0 & 5.3 & 4.1 & 3.2 & 2.9 & 0.27 \\
\hline $4 C$ & Eugene & OR & 4638 & 270 & 1355 & 22.64 & 23.4 & 91.7 & 84.8 & 0.0906 & 5.0 & 1.0 & 5.6 & 5.5 & 3.4 & 3.9 & 0.24 \\
\hline $4 c$ & Portland & OR & 4214 & 433 & 1286 & 28.04 & 25.2 & 91.4 & 87 & 0.0906 & 4.8 & 1.1 & 5.6 & 5.6 & 3.3 & 3.9 & 0.27 \\
\hline
\end{tabular}




\begin{tabular}{|c|c|c|c|c|c|c|c|c|c|c|c|c|c|c|c|c|c|}
\hline Zone & City & State & $\begin{array}{l}\mathscr{0} \\
\hat{⿵} \\
\hat{\Xi}\end{array}$ & 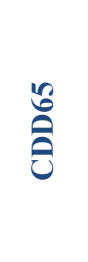 & 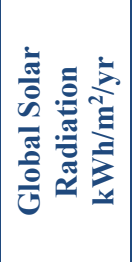 & 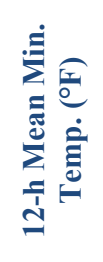 & 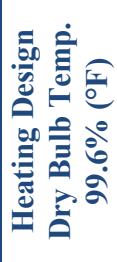 & 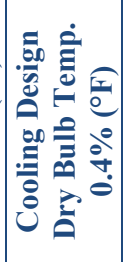 & 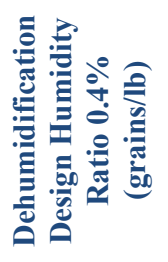 & 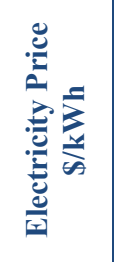 & 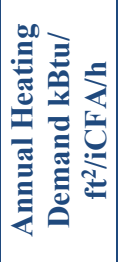 & 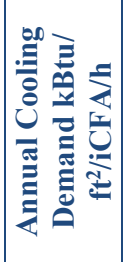 & 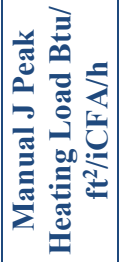 & 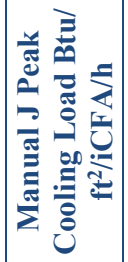 & 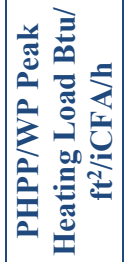 & 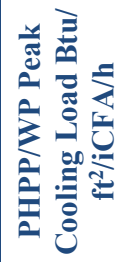 & 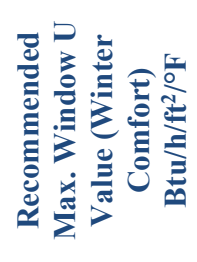 \\
\hline $4 C$ & Salem & OR & 4533 & 313 & 1352 & 15.26 & 23.5 & 92.3 & 82.2 & 0.0906 & 4.9 & 1.0 & 5.6 & 5.6 & 3.4 & 3.9 & 0.20 \\
\hline $4 \mathrm{~A}$ & Philadelphia & PA & 4512 & 1332 & 1469 & 9.68 & 13.8 & 93.4 & 133.4 & 0.1189 & 4.5 & 5.4 & 6.1 & 6.7 & 3.7 & 4.7 & 0.19 \\
\hline $5 \mathrm{~A}$ & Pittsburgh & PA & 5583 & 782 & 1392 & 1.04 & 5.2 & 89.7 & 125 & 0.1189 & 5.4 & 3.1 & 6.6 & 5.9 & 4.0 & 4.2 & 0.16 \\
\hline $6 \mathrm{~A}$ & Montreal & QC & 7885 & 470 & 1352 & -9.22 & -9.8 & 86.1 & 114.5 & 0.0679 & 7.6 & 1.8 & 7.7 & 5.4 & 4.6 & 3.7 & 0.14 \\
\hline 7 & Quebec & QC & 9104 & 238 & 1299 & -15.88 & -14.9 & 84 & 111.5 & 0.0679 & 8.6 & 1.0 & 7.8 & 5.1 & 4.7 & 3.6 & 0.13 \\
\hline $5 \mathrm{~A}$ & Providence & RI & 5562 & 743 & 1390 & 8.6 & 8.5 & 90.1 & 126.5 & 0.1304 & 5.3 & 3.0 & 6.3 & 6.0 & 3.8 & 4.2 & 0.18 \\
\hline 3A & Charleston & $\mathrm{SC}$ & 1880 & 2357 & 1676 & 25.7 & 27.3 & 94.3 & 150 & 0.1093 & 2.1 & 10.5 & 5.7 & 7.5 & 3.4 & 5.2 & 0.26 \\
\hline $6 \mathrm{~A}$ & Rapid City & $\mathrm{SC}$ & 7000 & 671 & 1539 & -13.36 & -9.2 & 97.2 & 109.5 & 0.0896 & 6.4 & 2.3 & 7.6 & 6.6 & 4.6 & 4.6 & 0.13 \\
\hline $6 \mathrm{~A}$ & Huron & $\mathrm{SD}$ & 7604 & 757 & 1493 & -20.6 & -14.6 & 94.1 & 132.2 & 0.0896 & 6.9 & 3.2 & 7.9 & 6.5 & 4.7 & 4.6 & 0.12 \\
\hline $6 \mathrm{~A}$ & Pierre & SD & 7109 & 899 & 1494 & -27.6 & -11 & 98.9 & 123.2 & 0.0896 & 6.5 & 3.4 & 7.7 & 7.0 & 4.6 & 4.9 & 0.11 \\
\hline $6 \mathrm{~A}$ & Watertown & $\mathrm{SD}$ & 8377 & 534 & 1291 & -29.7 & -15.6 & 90 & 129.5 & 0.0896 & 7.9 & 2.3 & 7.8 & 5.9 & 4.7 & 4.2 & 0.11 \\
\hline $4 \mathrm{~A}$ & Knoxville & $\mathrm{TN}$ & 3594 & 1514 & 1565 & 11.12 & 16.5 & 93 & 131.5 & 0.0946 & 3.7 & 6.0 & 6.3 & 6.7 & 3.8 & 4.7 & 0.19 \\
\hline $3 \mathbf{A}$ & Memphis & $\mathrm{TN}$ & 2898 & 2253 & 1640 & 14.72 & 18.7 & 96.7 & 141.9 & 0.0946 & 3.1 & 9.5 & 6.3 & 7.7 & 3.8 & 5.4 & 0.20 \\
\hline $4 \mathrm{~A}$ & Nashville & $\mathrm{TN}$ & 3518 & 1729 & 1577 & 10.4 & 14.8 & 94.8 & 135 & 0.0946 & 3.7 & 7.0 & 6.5 & 7.1 & 3.9 & 5.0 & 0.19 \\
\hline $4 B$ & Amarillo & $\mathrm{TX}$ & 4102 & 1366 & 1817 & 9.5 & 9.8 & 97.3 & 114.9 & 0.1033 & 3.5 & 4.7 & 6.7 & 7.0 & 4.0 & 4.9 & 0.18 \\
\hline $2 \mathrm{~A}$ & Austin & $\mathrm{TX}$ & 1671 & 2962 & 1667 & 26.42 & 26.6 & 99.8 & 141.9 & 0.1033 & 2.0 & 12.4 & 5.9 & 8.7 & 3.5 & 6.1 & 0.26 \\
\hline $2 A$ & Brownsville & $\mathrm{TX}$ & 538 & 3986 & 1696 & $\# \mathrm{~N} / \mathrm{A}$ & 38.1 & 95.4 & 152.2 & 0.1033 & 1.1 & 17.8 & 5.2 & 8.5 & 3.1 & 6.0 & \#N/A \\
\hline 3B & El Paso & $\mathrm{TX}$ & 2383 & 2379 & 2065 & 28.76 & 23.9 & 100.7 & 114.3 & 0.1033 & 1.8 & 8.0 & 5.9 & 8.2 & 3.6 & 5.7 & 0.28 \\
\hline $3 \mathbf{A}$ & Fort Worth & $\mathrm{TX}$ & 2149 & 2785 & 1732 & 18.68 & 22 & 100.5 & 137.9 & 0.1033 & 2.3 & 11.3 & 6.1 & 8.7 & 3.7 & 6.1 & 0.22 \\
\hline $2 A$ & Houston & $\mathrm{TX}$ & 1371 & 3059 & 1630 & 24.8 & 30.3 & 97.2 & 147.1 & 0.1033 & 1.9 & 13.3 & 5.6 & 8.3 & 3.4 & 5.8 & 0.25 \\
\hline $2 A$ & Port Arthur & $\mathrm{TX}$ & 1356 & 2899 & 1654 & 28.76 & 31.4 & 94.5 & 153 & 0.1033 & 1.8 & 13.1 & 5.6 & 7.8 & 3.3 & 5.5 & 0.28 \\
\hline $2 A$ & San Antonio & $\mathrm{TX}$ & 1418 & 3157 & 1800 & 25.16 & 29.2 & 99 & 139.9 & 0.1033 & 1.6 & 13.0 & 5.7 & 8.7 & 3.4 & 6.1 & 0.25 \\
\hline $2 \mathrm{~A}$ & Victoria & $\mathrm{TX}$ & 1185 & 3193 & 1680 & 24.98 & 31 & 97.1 & 150.9 & 0.1033 & 1.7 & 14.2 & 5.6 & 8.4 & 3.4 & 5.9 & 0.25 \\
\hline 5B & Salt Lake City & UT & 5507 & 1218 & 1663 & 12.9 & 9.6 & 97.7 & 90.7 & 0.0893 & 5.0 & 3.2 & 6.5 & 6.7 & 3.9 & 4.7 & 0.20 \\
\hline $4 A$ & Charlottesville & VA & 4211 & 1150 & 1421 & 9.32 & 16.4 & 93 & 126.6 & 0.1044 & 4.4 & 4.5 & 6.1 & 6.5 & 3.7 & 4.5 & 0.18 \\
\hline 4 & Norfolk & VA & 3230 & 1700 & 1545 & 21.38 & 22.5 & 93.7 & 139.2 & 0.1044 & 3.5 & 7.1 & 5.9 & 7.0 & 3.5 & 4.9 & 0.23 \\
\hline
\end{tabular}


U.S. DEPARTMENT OF | Energy Efficiency \&

Renewable Energy

\begin{tabular}{|c|c|c|c|c|c|c|c|c|c|c|c|c|c|c|c|c|c|}
\hline Zone & City & State & $\begin{array}{l}\mathscr{O} \\
\hat{\widehat{E}}\end{array}$ & 气ิ & 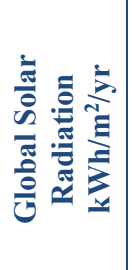 & 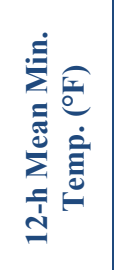 & 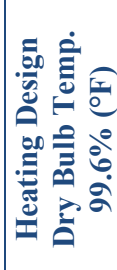 & 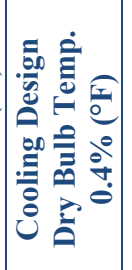 & 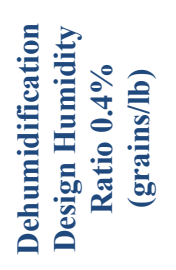 & 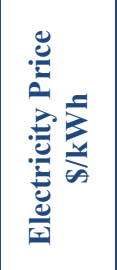 & 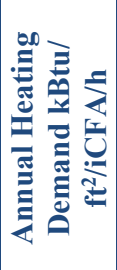 & 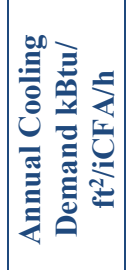 & 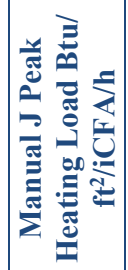 & 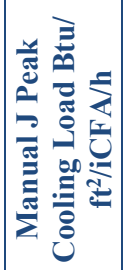 & 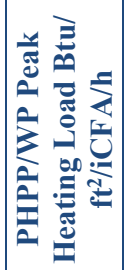 & 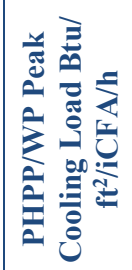 & 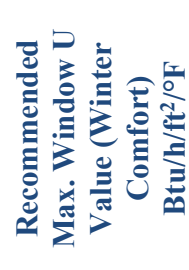 \\
\hline $4 \mathrm{~A}$ & Roanoke & VA & 4044 & 1230 & 1542 & 15.44 & 15.7 & 92.3 & 125.3 & 0.1044 & 4.1 & 4.7 & 6.2 & 6.4 & 3.7 & 4.5 & 0.21 \\
\hline $6 \mathrm{~A}$ & Burlington & VT & 7352 & 505 & 1340 & -13.9 & -7.8 & 88.4 & 117.1 & 0.1593 & 6.6 & 1.9 & 6.9 & 5.6 & 4.1 & 3.9 & 0.13 \\
\hline $4 C$ & Seattle & WA & 4705 & 188 & 1240 & 21.2 & 25.2 & 85.3 & 81.4 & 0.0779 & 5.4 & 1.0 & 5.6 & 4.8 & 3.4 & 3.4 & 0.23 \\
\hline 5B & Spokane & WA & 6627 & 434 & 1410 & 4.1 & 4.7 & 92.8 & 77.3 & 0.0779 & 6.4 & 1.0 & 6.8 & 5.6 & 4.1 & 3.9 & 0.17 \\
\hline $6 A$ & Green Bay & WI & 7599 & 479 & 1376 & -15.34 & -8.2 & 88.5 & 127.8 & 0.1181 & 7.0 & 2.1 & 7.2 & 5.8 & 4.3 & 4.0 & 0.13 \\
\hline $6 \mathrm{~A}$ & Madison & WI & 7104 & 620 & 1426 & -18.76 & -7 & 89.6 & 130.4 & 0.1181 & 6.5 & 2.6 & 7.2 & 5.9 & 4.3 & 4.2 & 0.12 \\
\hline $4 \mathrm{~A}$ & Huntington & WV & 4426 & 1156 & 1446 & 5.54 & 10.1 & 91.9 & 133.1 & 0.0915 & 4.6 & 4.7 & 6.7 & 6.4 & 4.0 & 4.5 & 0.17 \\
\hline $6 B$ & Casper & WY & 7285 & 461 & 1577 & -13.54 & -8.3 & 93.8 & 85.9 & 0.0896 & 6.5 & 1.2 & 7.5 & 5.8 & 4.5 & 4.1 & 0.13 \\
\hline $6 \mathrm{~B}$ & Sheridan & WY & 7392 & 454 & 1533 & -9.4 & -10.7 & 95.3 & 94.4 & 0.0896 & 6.7 & 1.3 & 7.7 & 6.1 & 4.6 & 4.2 & 0.14 \\
\hline
\end{tabular}




\section{Appendix D: Statistical Modeling-Example Screening Fit}

Screening fit:

\section{Response Cooling Capacity Btu/h/ft $\mathbf{f t}^{2} / \mathbf{i C F A}$}

\section{Actual by Predicted Plot}
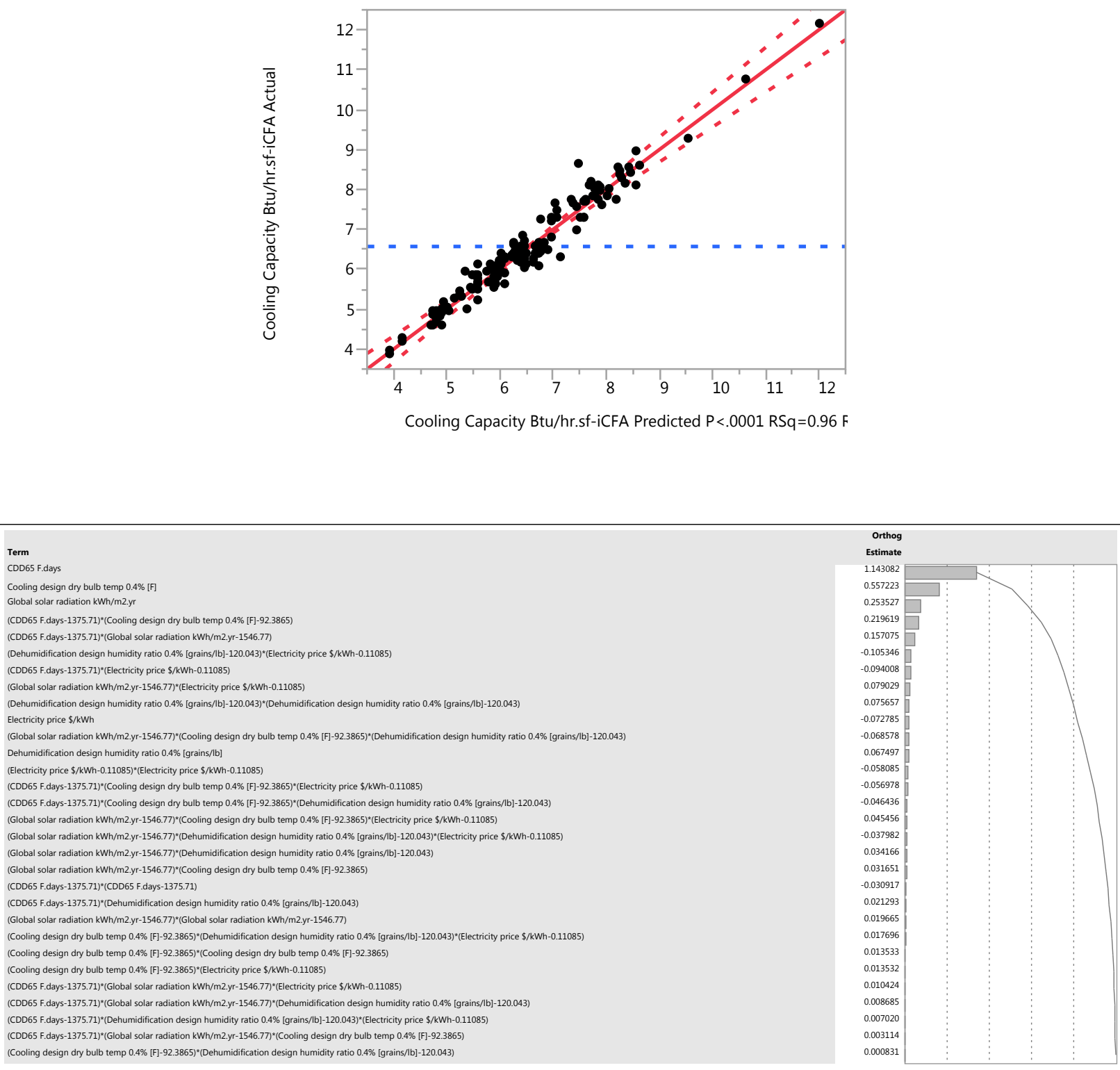

Final fit:

The R-squared and RMS error are almost as good, and the model is a lot simpler. 


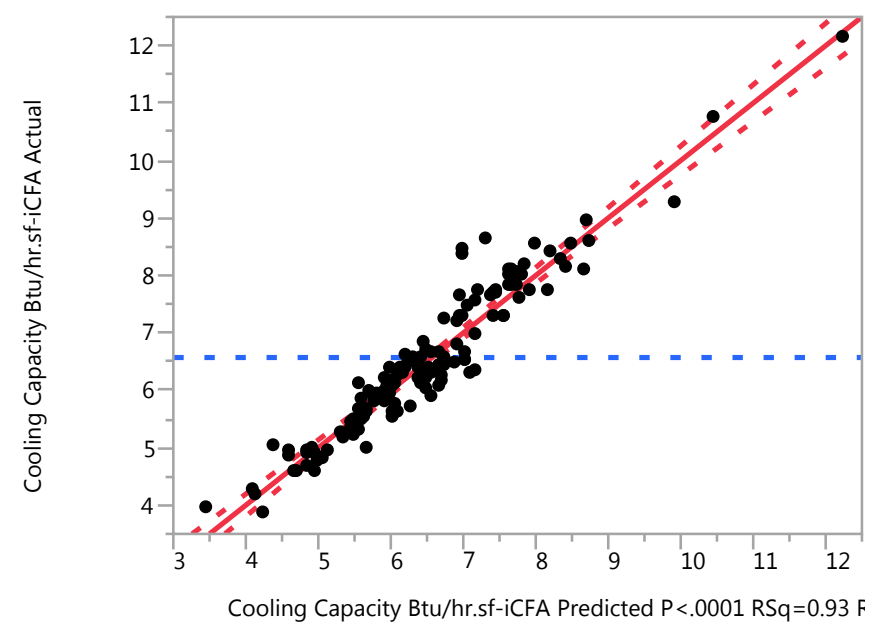

Sorted Parameter Estimates

Term

Estimate

Cooling design dry bulb temp $0.4 \%$ (F)

(Cooling design dry bulb temp $0.4 \%(F)$ 92.3865)*(CDD65 F.days-1375.71)

CDD65 F.days

Dehumidification design humidity ratio

$0.4 \%$ (grains $/ \mathrm{lb}$ )
0.1365094

$3.6453 \mathrm{e}-5$

0.0003903

0.0115813
Std Error

0.006333

$3.966 \mathrm{e}-6$

0.000043

0.001847 t Ratio t Ratio

21.56

9.19

9.08

6.27

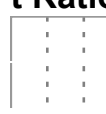

\begin{tabular}{l|l} 
& Prob $>|\mathbf{t}|$ \\
$\vdots$ & $<.0001^{*}$ \\
$\vdots$ & $<.0001^{*}$
\end{tabular}

$<.0001^{*}$

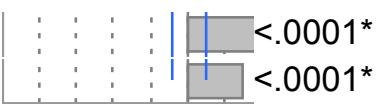

\section{Prediction Profiler}
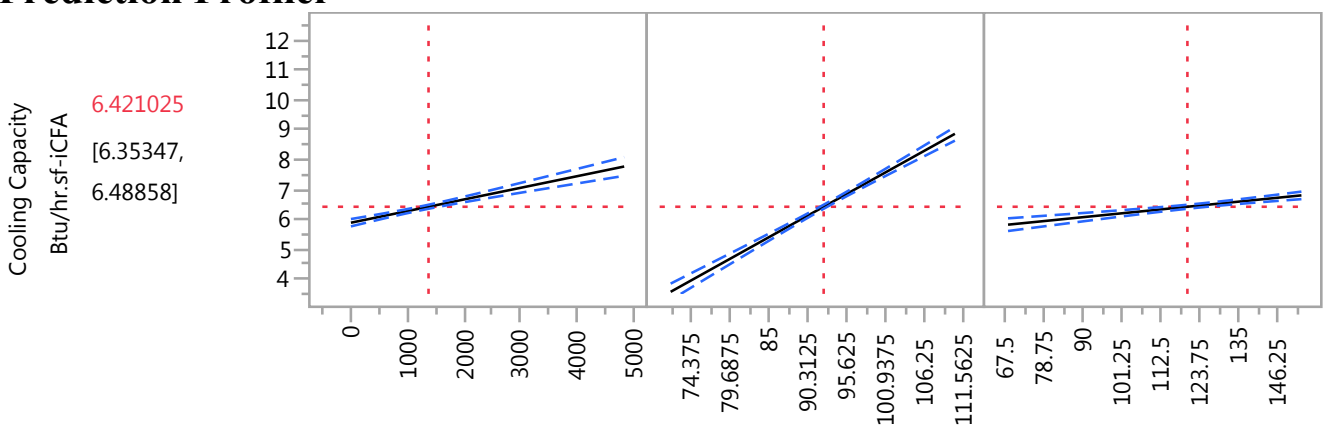

1375.7

92.387

120.043

CDD65

Cooling design dry

ımidification design

F.days

bulb temp $0.4 \%[\mathrm{~F}]$

idity ratio $0.4 \%$ [grains/lb] 


\section{Appendix E: Passive (and "Low-Grade-Energy") Measures and Strategies}

This list is from the charter of the nascent Global Passive Building Council.

Building site selection and orientation

Building size, shape, spacing

Thermal mass (as appropriate)

Solar protection and shading (e.g., vegetation, roof overhangs)

Daylighting design, window placement, selection of glazing properties

Passive solar gains (in moderation)

Coupling to the earth (as appropriate)

Ventilation (natural or mechanical, with heat-and-moisture recovery as appropriate)

Night flush ventilation as appropriate (i.e., wide daily outside temperature swing)

Evaporative cooling as appropriate (i.e., hot dry climates)

Air-sealing, airtight construction

Continuous insulation, connection details free of thermal bridges

Safe handling of air for combustion 
buildingamerica.gov

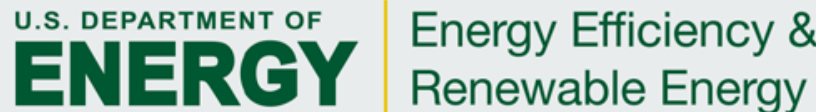

